\title{
HYDROLOGY OF AREA 11, EASTERN COAL PROVINCE, OHIO, KENTUCKY, AND WEST VIRGINIA
}

- LITTLE SCIOTO RIVER

- LITTLE SANDY RIVER

- MIDDLE OHIO RIVER

- RACCOON CREEK

- TYGARTS CREEK

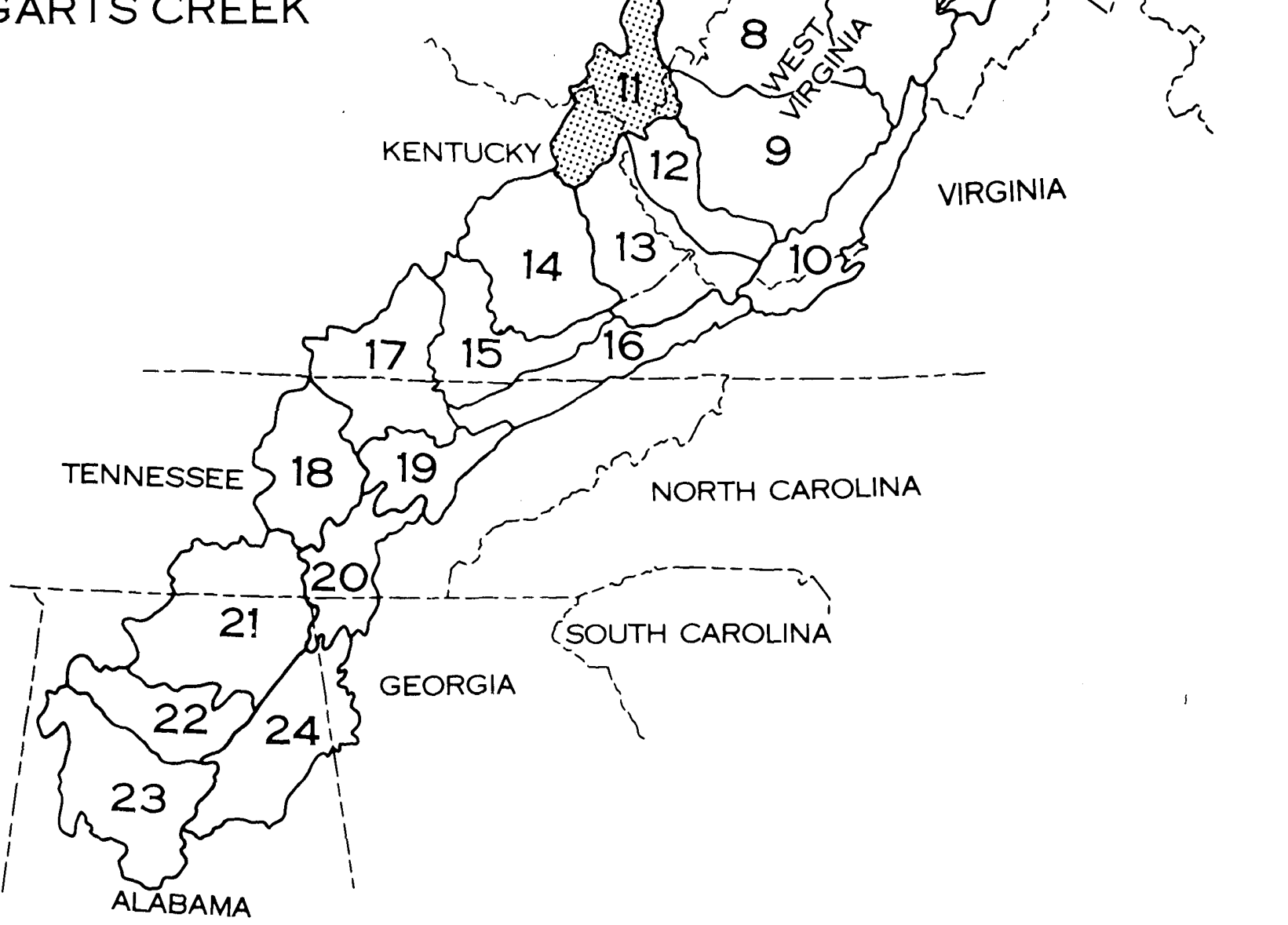

UNITED STATES DEPARTMENT OF THE INTERIOR GEOLOGICAL SURVEY 



\section{HYDROLOGY OF AREA 11, EASTERN COAL PROVINCE, OHIO, KENTUCKY, AND WEST VIRGINIA}

BY

D.K. ROTH AND S.C. COOPER

U.S. GEOLOGICAL SURVEY

WATER-RESOURCES IN VESTIGATIONS

OPEN-FILE REPORT 84-233

COLUMBUS, OHIO SEPTEMBER, 1984 


\title{
UNITED STATES DEPARTMENT OF THE INTERIOR
}

\author{
WILLIAM P. CLARK. SECRETARY
}

GEOLOGICAL SURVEY

Dallas L. Peck, Director

For additional information write to:

District Chief

Water Resources Division

U.S. Geological Survey

$975 \mathrm{~W}$. Third Avenue

Columbus, Ohio 43212 


\section{CONTENTS}

Page

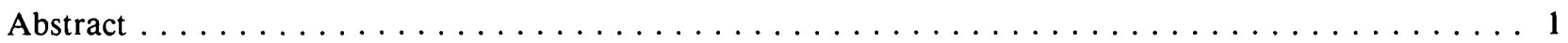

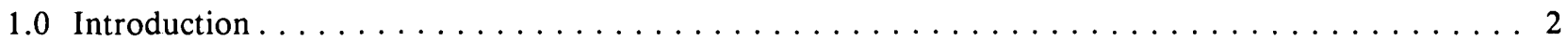

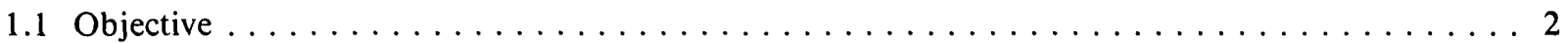

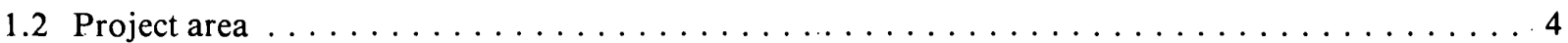

1.3 Hydrologic problems related to coal mining $\ldots \ldots \ldots \ldots \ldots \ldots \ldots \ldots \ldots \ldots \ldots \ldots \ldots \ldots$

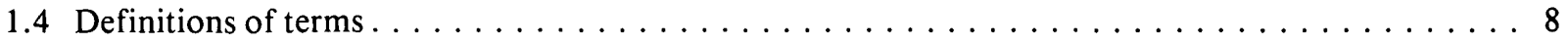

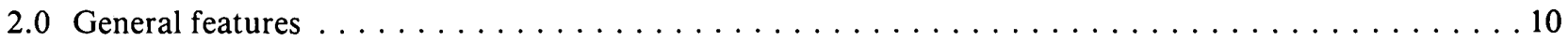

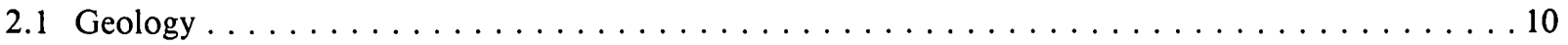

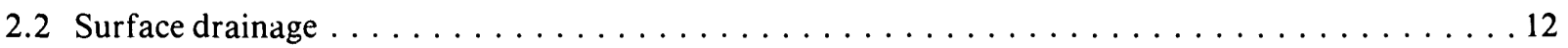

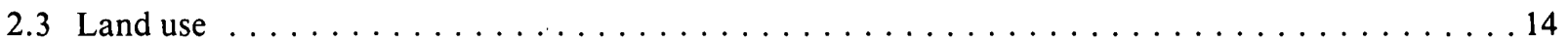

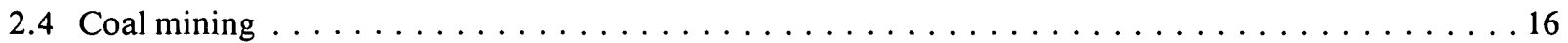

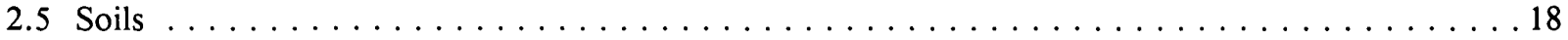

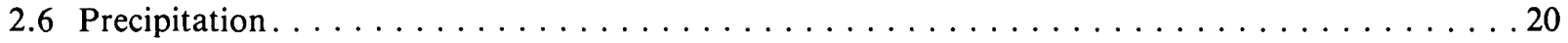

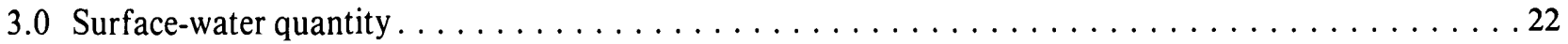

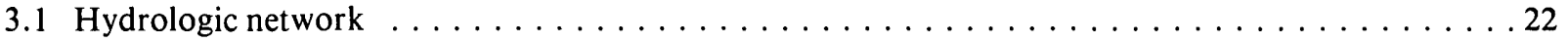

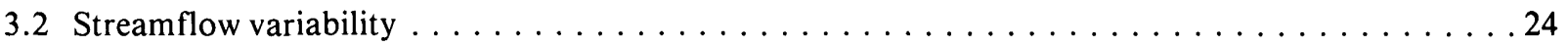

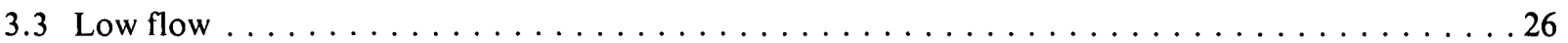

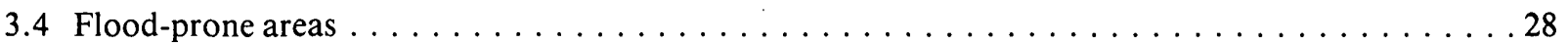

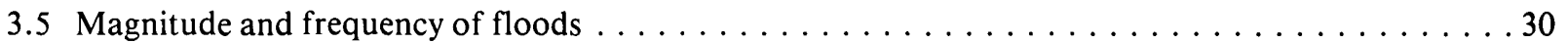

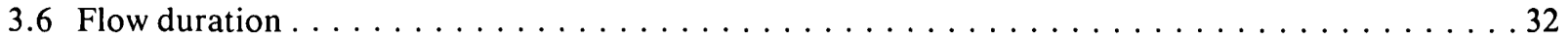

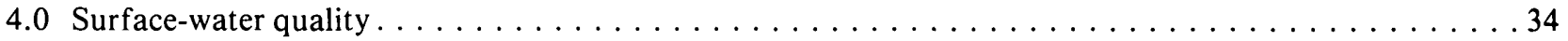

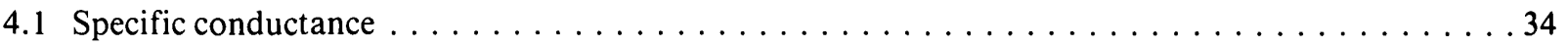

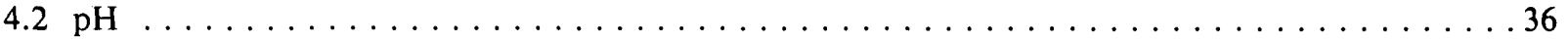

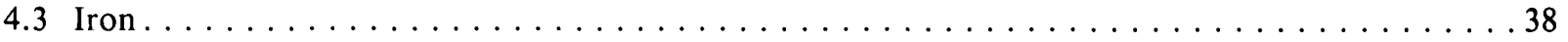

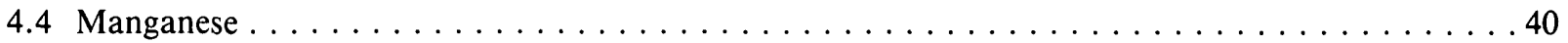

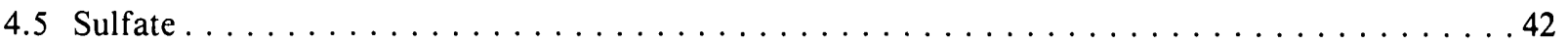

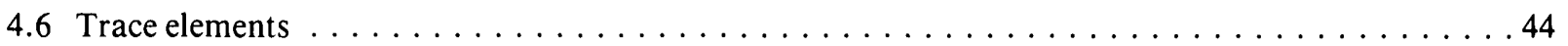

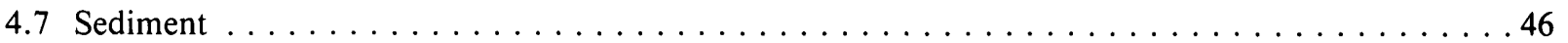

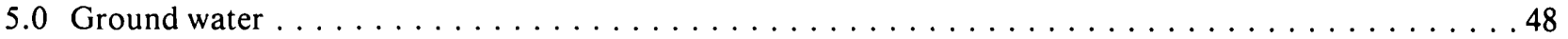

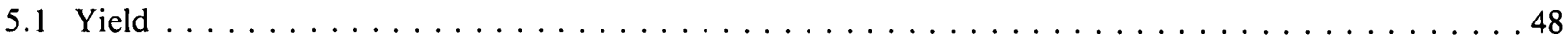

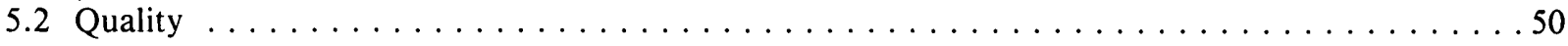




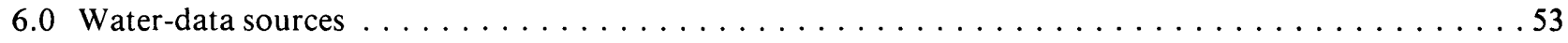

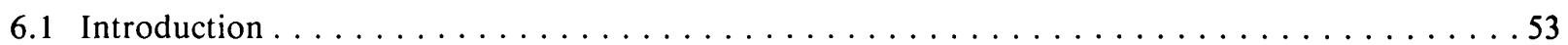

6.2 National water-data exchange $($ NAWDEX) $\ldots \ldots \ldots \ldots \ldots$

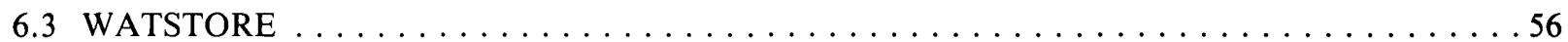

6.4 Index to water-data activities in coal provinces $\ldots \ldots \ldots \ldots$

7.0 Supplemental information for Area $11 \ldots \ldots \ldots$

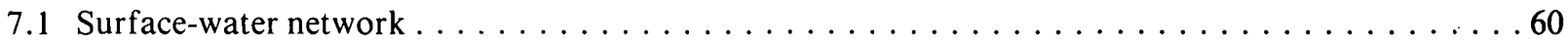

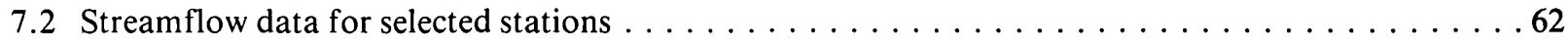

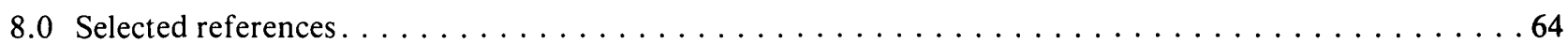




\section{FACTORS FOR CONVERTING INCH-POUND UNITS TO INTERNATIONAL SYSTEM OF UNITS (SI)}

For the convenience of readers who may want to use the International System of Units (SI), the data may be converted by using the following factors:

\section{Multiply}

inches (in)

feet (ft)

miles (mi)

square miles $\left(\mathrm{mi}^{2}\right)$

cubic feet per second $\left(\mathrm{ft}^{3} / \mathrm{s}\right)$

cubic feet per second

per square mile $\left[\left(\mathrm{ft}^{3} / \mathrm{s}\right) / \mathrm{mi}^{2}\right]$

tons per square mile per

year $\left[\left(\operatorname{ton} / \mathrm{mi}^{2}\right) / \mathrm{yr}\right]$

micromhos per centimeter at $25^{\circ}$ Celsius $(\mu \mathrm{mhos} / \mathrm{cm})$
By

25.4

0.3048

1.609

2.590

0.02832

0.01093

0.3503

100

\section{To obtain}

millimeters (mm)

meters (m)

kilometers $(\mathrm{km})$

square kilometers $\left(\mathrm{km}^{2}\right)$

cubic meters per second $\left(\mathrm{m}^{3} / \mathrm{s}\right)$

cubic meters per second per square kilometer $\left[\left(\mathrm{m}^{3} / \mathrm{s}\right) / \mathrm{km}^{2}\right]$

metric tons per square kilometer per year $\left[\left(\mathrm{t} / \mathrm{km}^{2}\right) / \mathrm{a}\right]$

microsiemens per meter at $25^{\circ}$ Celsius $(\mu \mathrm{S} / \mathrm{m})$

National Geodetic Vertical Datum of 1929 (NGVD of 1929): A geodetic datum derived from a general adjustment of the first-order level nets of both the United States and Canada, formerly called mean sea level. NGVD of 1929 is referred to as sea level in this report. 


\title{
HYDROLOGY OF AREA 11, EASTERN COAL PROVINCE, OHIO, KENTUCKY, AND WEST VIRGINIA
}

BY

D.K. ROTH AND S.C. COOPER

\begin{abstract}
The Eastern Coal Province is divided into 24 separate hydrologic reporting areas. The division is based on hydrologic factors, location, size, and mining activity. Area 11 of the Eastern Coal Province comprises 3,190 square miles of southeastern Ohio, northeastern Kentucky, and western West Virginia. Except for the wide, flat flood plain along the Ohio River, it consists mainly of rolling hills. Most of the area is forested. Precipitation in the area ranges from 39 inches per year in the north to 45 inches per year in the south.

Coal seams 1 to 4 feet thick are found in rocks of Pennsylvanian age that crop out in Area 11. Surface mining of coal is concentrated in the Ohio part; surface mines are scattered throughout the Kentucky part, and there are no known mines in the West Virginia part.

Area 11 is entirely within the Ohio River drainage basin. The major tributaries to the Ohio River in the area are Raccoon Creek, Symmes Creek, Little Scioto River, Pine Creek, Indian Guyan Creek, Little Sandy River, and Tygarts Creek. The average annual discharge of streams in Area 11 (based on 10 stations) is 1.23 cubic feet per second per square mile of drainage area. Most of the streams that drain less than 100 square miles normally approach zero flow

stations) is 0.37 cubic feet per second per square mile. The 2-year flood-peak magnitude (based on seven stations) ranges from 10.8 to 138 cubic feet per second per square mile; the average 2-year flood peak is 43.8 cubic feet per second per square mile.

The $\mathrm{pH}$ of sampled streams ranged from 2.6 to 8.8. The median $\mathrm{pH}$ at mined sites was 5.4 , whereas the median $\mathrm{pH}$ at unmined sites was 7.3. Dissolved iron concentrations ranged from 0 to 150,000 micrograms per liter; medians were 893 micrograms per liter at mined sites and 90 micrograms per liter at unmined sites. Specific conductance ranged from 95 to 3,000 micromhos per centimeter (at 25 degrees Celsius); medians for mined and unmined sites were 573 and 277 micromhos per centimeter, respectively. Sulfate concentrations ranged from 9.8 to 2,100 milligrams per liter; medians were 203 milligrams per liter at mined sites and 50 milligrams per liter at unmined sites.

Although water wells in alluvium along the Ohio River produce up to 1,500 gallons per minute, bedrock wells throughout most of Area 11 typically yield only 1 or 2 gallons per minute. Chemical analyses of ground water indicate that bicarbonate is the major anion in Area 11; calcium and sodium are the major cations.
\end{abstract} from late June through October. The average value of the 50-percent daily duration flow (based on eight 


\title{
1.0 INTRODUCTION \\ 1.1 Objective
}

\section{Area 11 Report to Aid in Preparing and Appraising Mine Permit Applications}

\begin{abstract}
The hydrologic information presented or available through sources identified in this report may be used in describing the "general area" of a proposed mine.
\end{abstract}

A need for hydrologic information and analysis on a scale never before required nationally was initiated when the "Surface Mining Control and Reclamation Act of 1977" was enacted as Public Law 95-87, August 3, 1977. This need is partially met by this report, which broadly characterizes the hydrology of a section of Ohio, Kentucky, and West Virginia (fig. 1.1-1). This report, which is for Area 11 of the Eastern Coal Province, is one of a series that covers the coal provinces nationwide. The report contains a brief text with an accompanying map, chart, graph, or other illustration for each of a number of waterresources-related topics.

The hydrologic information presented or available through sources identified in this report may be used to describe the hydrology of the "general area" of any proposed mine. Furthermore, it is expected that this hydrologic information will be supplemented by specific site data provided by lease applicants, as well as data from other sources, to provide a more detailed picture of the hydrology in the vicinity of the mine and the anticipated hydrologic consequences of the mining operation.

The information contained herein should be useful to surface mine owners, operators, and consulting engineers for preparing permits as well as to regulatory authorities for appraising the adequacy of permit applications. 


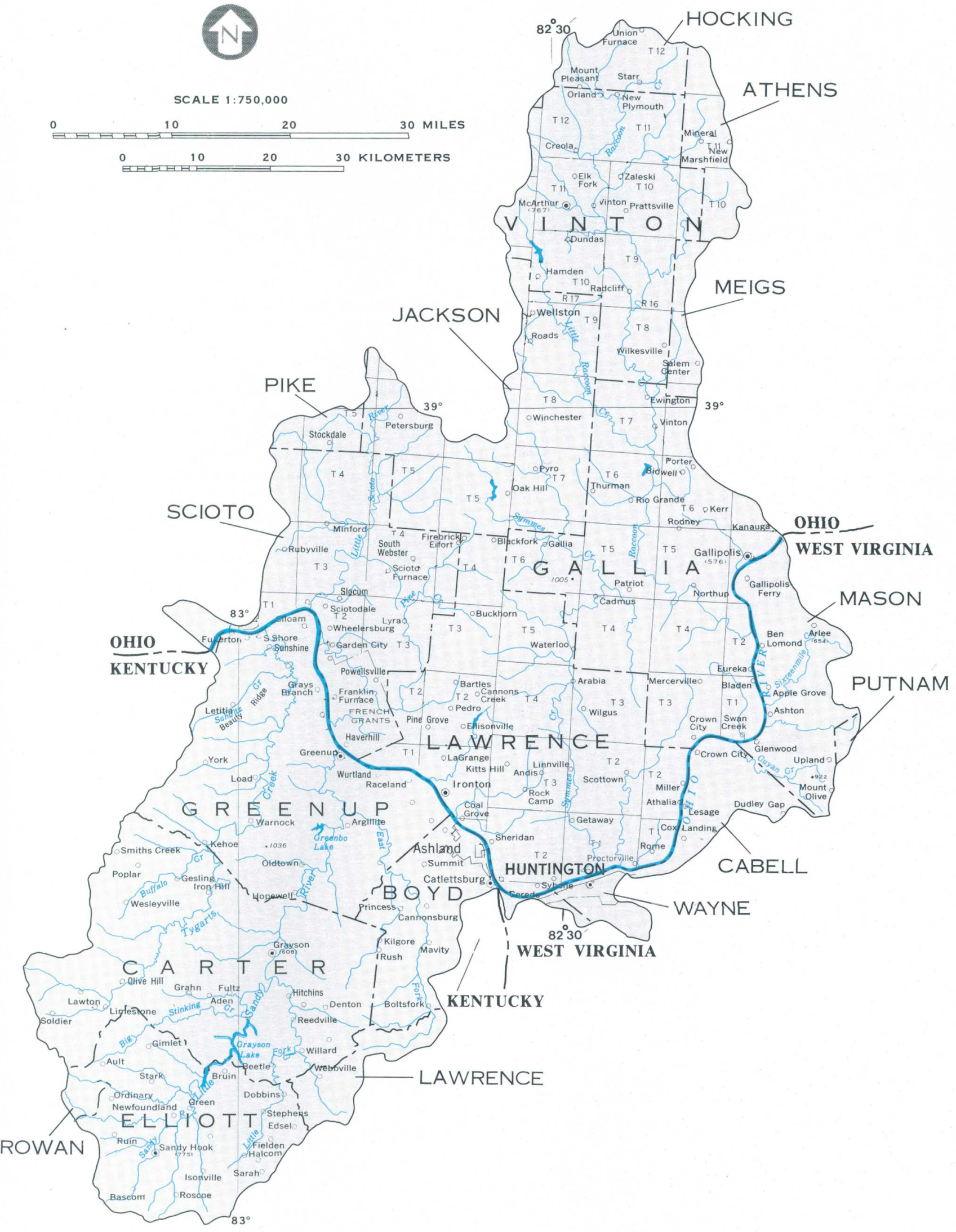

BASE FROM U.S. GEOLOGICAL SURVEY STATE BASE MAPS, 1973, 1974, 1975

Figure 1.1-1 Location of Area 11. 


\subsection{INTRODUCTION--Continued \\ 1.2 Project Area}

\section{Area 11 Spans Parts of Three States}

The area includes all or parts of eight counties in southeastern Ohio, five counties in northeastern Kentucky, and three counties in western West Virginia.

The Eastern Coal province is divided into 24 hydrologic reporting areas. The cover of this report shows the location of Area 11 in southeastern Ohio, northeastern Kentucky, and western West Virginia. The area includes all or parts of eight counties in Ohio, five counties in Kentucky, and three counties in West Virginia. Area 11 covers 3,190 square miles.

The area is drained by streams of the Ohio River basin. The main tributaries are the Little Sandy and Little Scioto Rivers, and Raccoon, Tygarts, and Symmes Creeks.
The terrain consists mainly of rolling hills, except for a wide, flat flood plain along the Ohio River. Population tends to concentrate in communities along the streams. The area is mainly forested, but some agriculture, industry, and commercial activity are found along the Ohio River.

Most of the coal mining in Area 11 is surface mining, but some underground mines are being worked as well. Figure 1.2-1 shows types of mining in Area 11. 


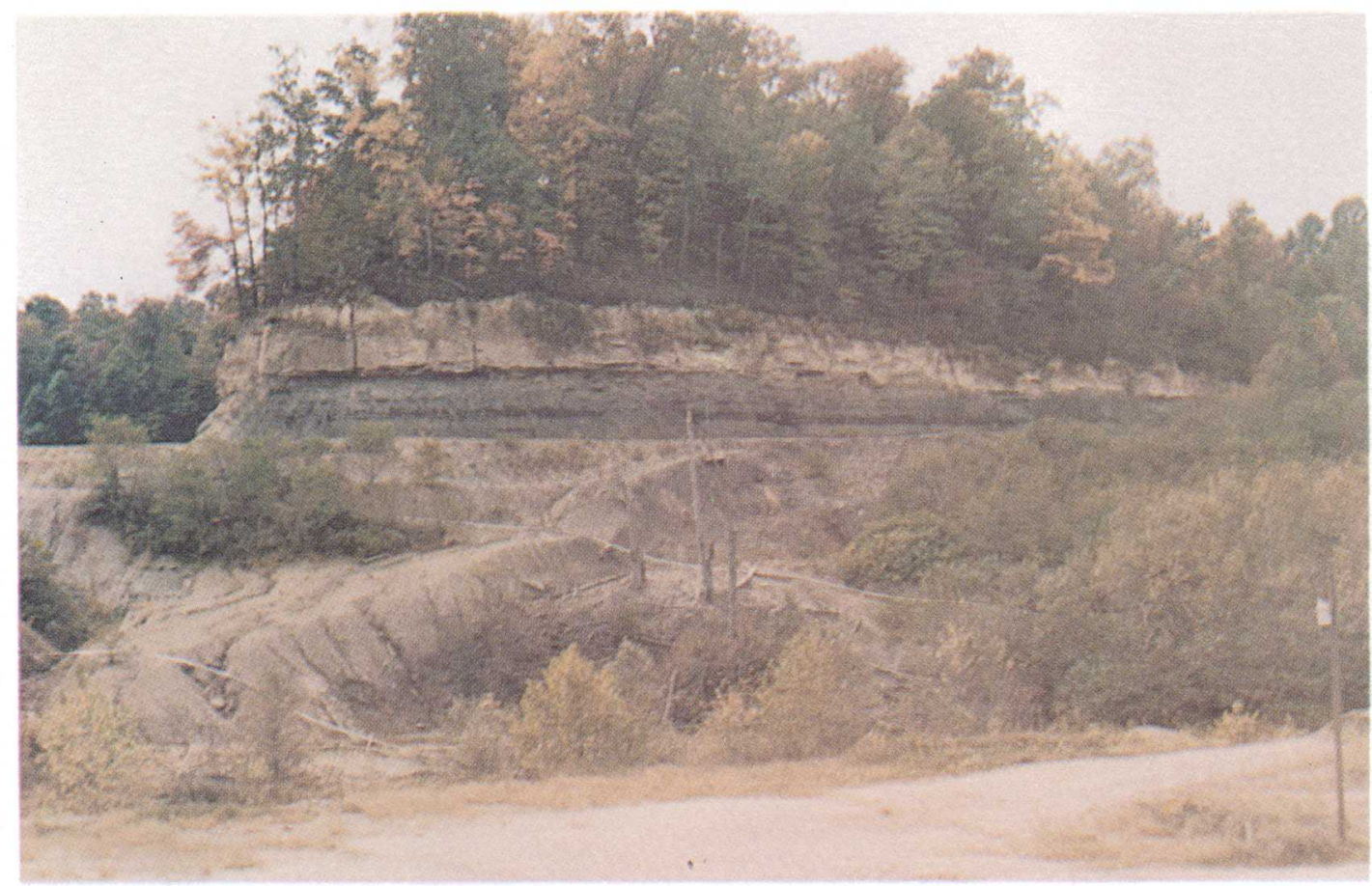

A. Surface (contour) mine, Jackson County, Ohio.

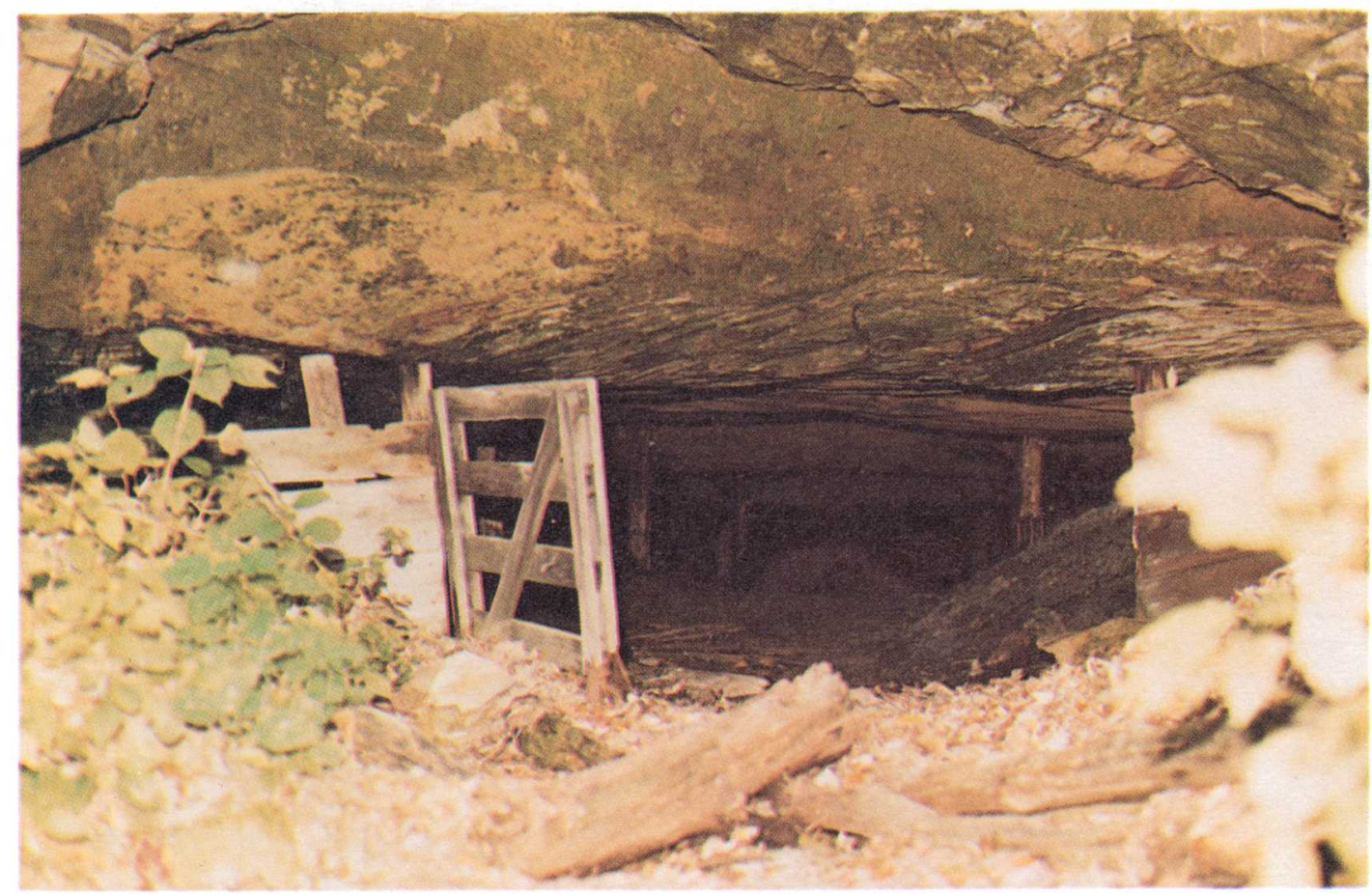

B. Underground (drift) mine, Vinton County, Ohio.

Figure 1.2-1 Types of mining in Area 11. 


\title{
1.0 INTRODUCTION--Continued
}

1.3 Hydrologic Problems Related to Coal Mining

\section{Hydrologic Environment Can Be Altered by Coal Mining}

\author{
Approximately 90 percent of the coal mining in Area 11 is surface mining; \\ adverse effects of surface mining are erosion and sedimentation, and to \\ some degree, acid mine drainage.
}

Surface and subsurface coal mining may cause detrimental changes to the natural environment. In areas where land has been reclaimed, the environmental stress has been reduced. In areas where land has not been reclaimed, the environment appears to have been damaged.

Approximately 90 percent of the coal mining in Area 11 is surface mining. The adverse effects of surface mining are erosion and sedimentation, and to some degree, acid mine drainage. Where vegetation has been removed, sediment can be eroded from the land at rates many times greater than from similar, undisturbed land.

The sediment from unreclaimed surface mines can reduce channel size, reduce storage in reservoirs, and reduce water-carrying capacity of receiving streams, and thus can increase flood potential. Sediment may also disrupt the ecosystem of streams by smothering bottom-dwelling organisms, destroying vital components of the aquatic food chain, and transporting and concentrating metals and nutrients.

Acid mine drainage is a water-quality problem associated with surface and underground mining. About 75 percent of the acid mine drainage in Appalachia originates in underground mines; the remaining 25 percent has been attributed to surface mines (Ohio Board on Unreclaimed Strip-Mined Lands, 1974). Iron-bearing minerals (pyrite and marcasite) commonly are exposed in the spoil materials and in the coal beds of surface and under-ground mines. When these exposed minerals react with the air, ferrous disulfide in the minerals oxidizes to form sulfuric acid and ferrous sulfate. Acid and ferrous sulfate may eventually be flushed from spoil piles and abandoned mines into nearby streams to the detriment of surface water and ground water. Streams draining such a mined area are acidic and hard, and carry increased concentrations of iron, sulfate, aluminum, manganese, and trace elements. High concentrations of these constituents can reduce the number and the diversity of aquatic organisms, increase corrosiveness of the water, limit domestic use of the water, and reduce the aesthetic value and recreational use of the water. Figure 1.3-1 depicts some of the adverse effects of mining in the study area. 


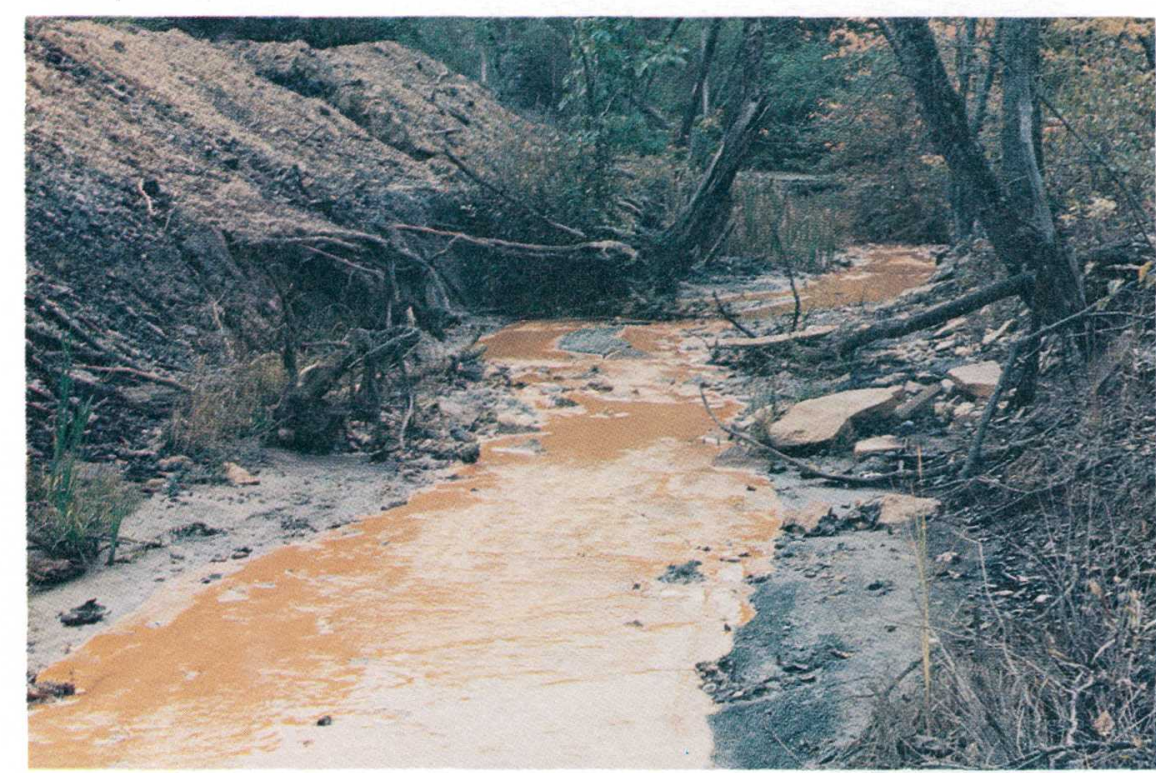

A. Acid mine drainage and sediment deposition from abandoned mine in Vinton County, Ohio

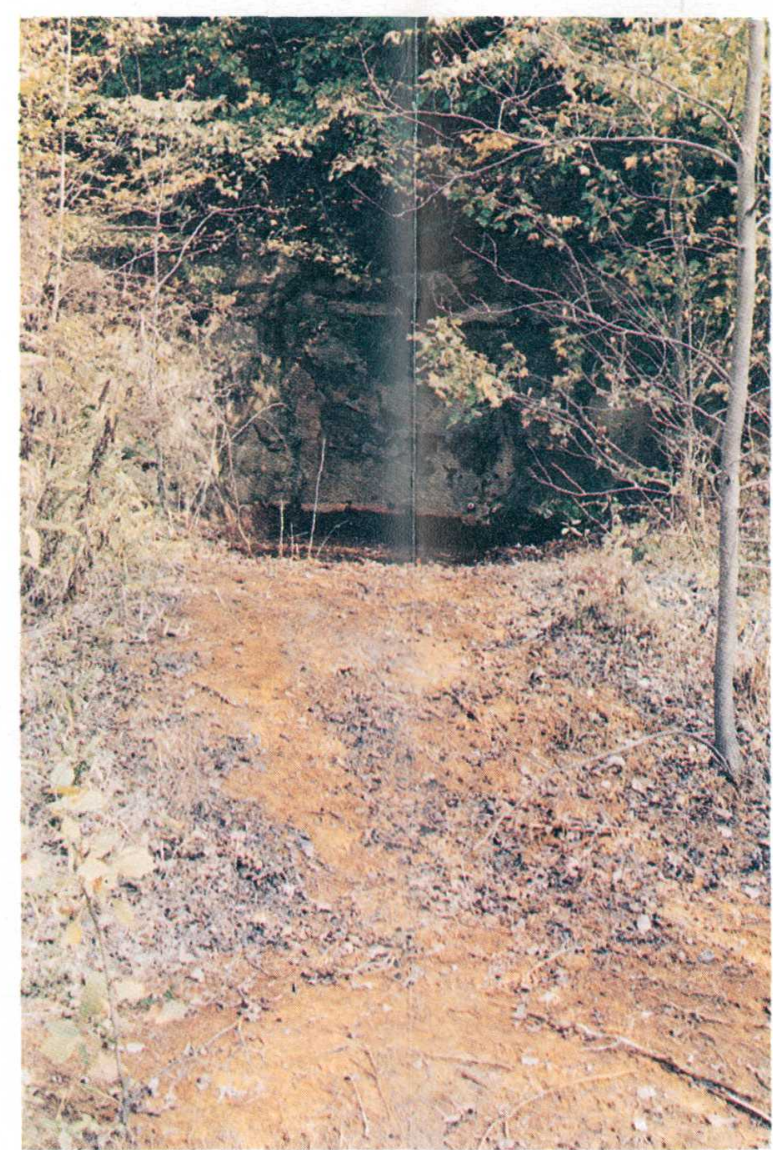

B. Acid mine drainage from abandoned underground mine in Vinton County, Ohio.

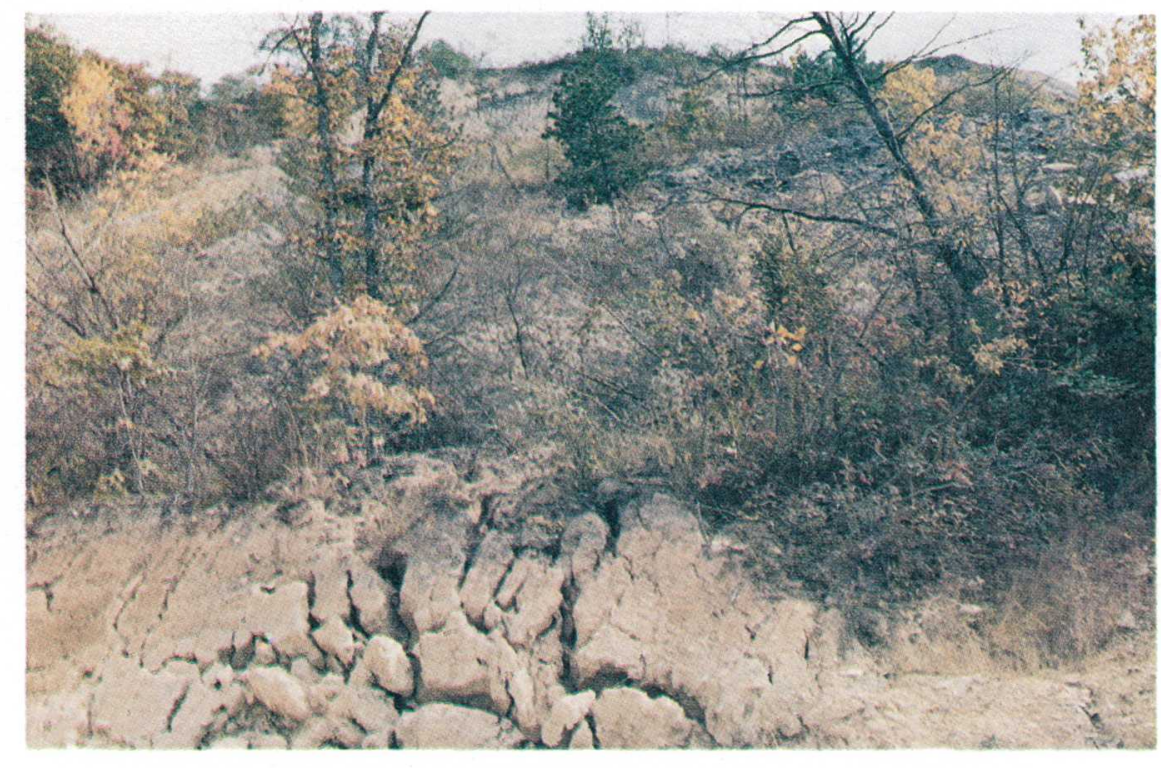

D. Erosion below abandoned surface mine in Meigs County, Ohio.

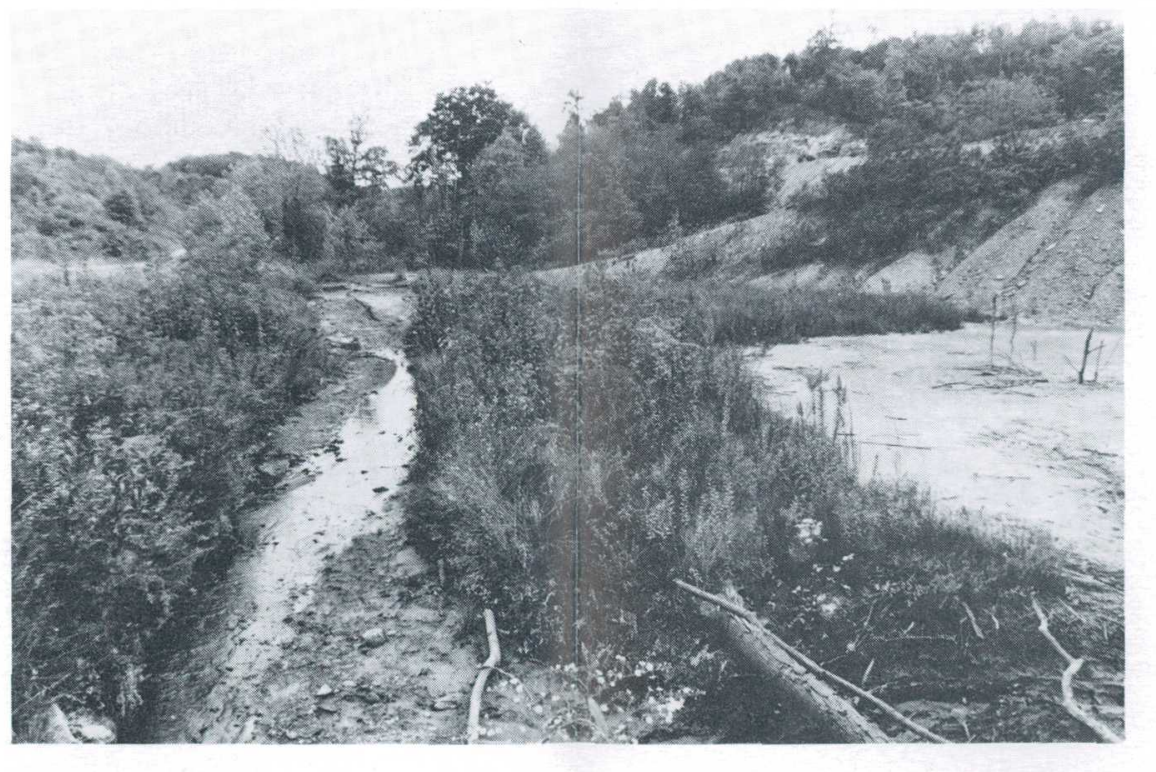

E. Sediment and erosion in an abandoned surface mine in Jackson, County, Ohio

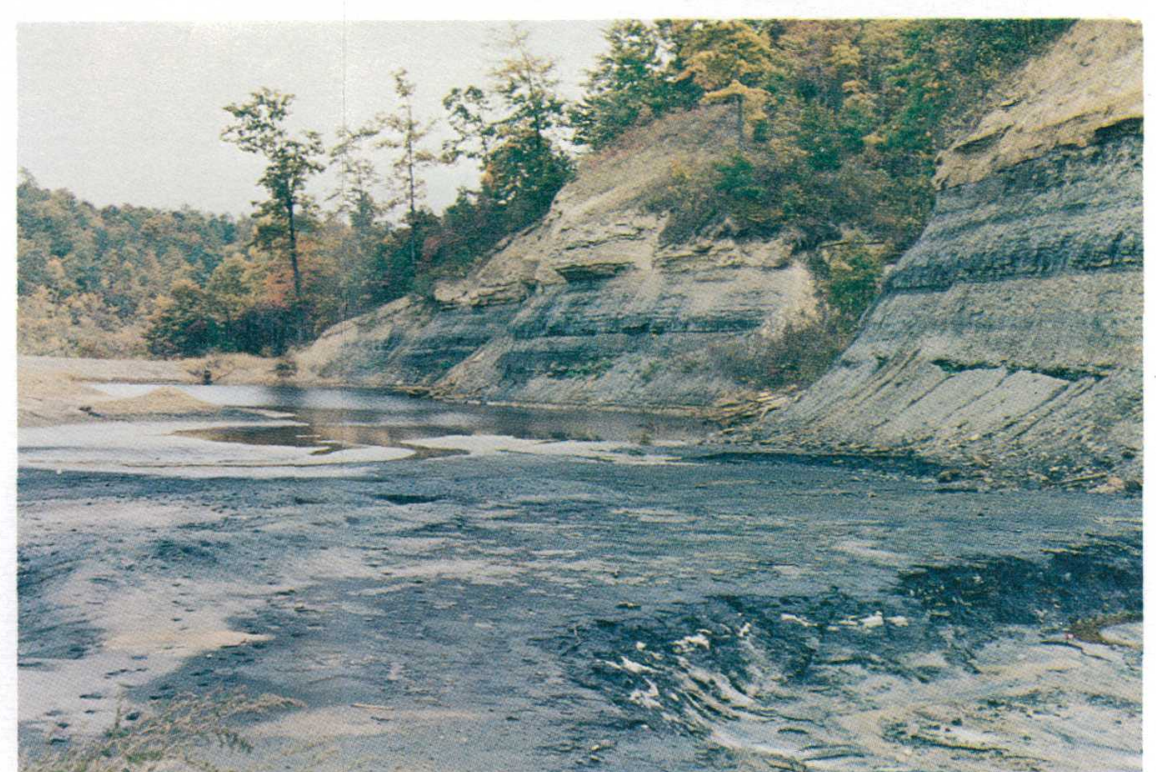

C. Erosion, sedimentation, and acid mine drainage from abandoned surface mine

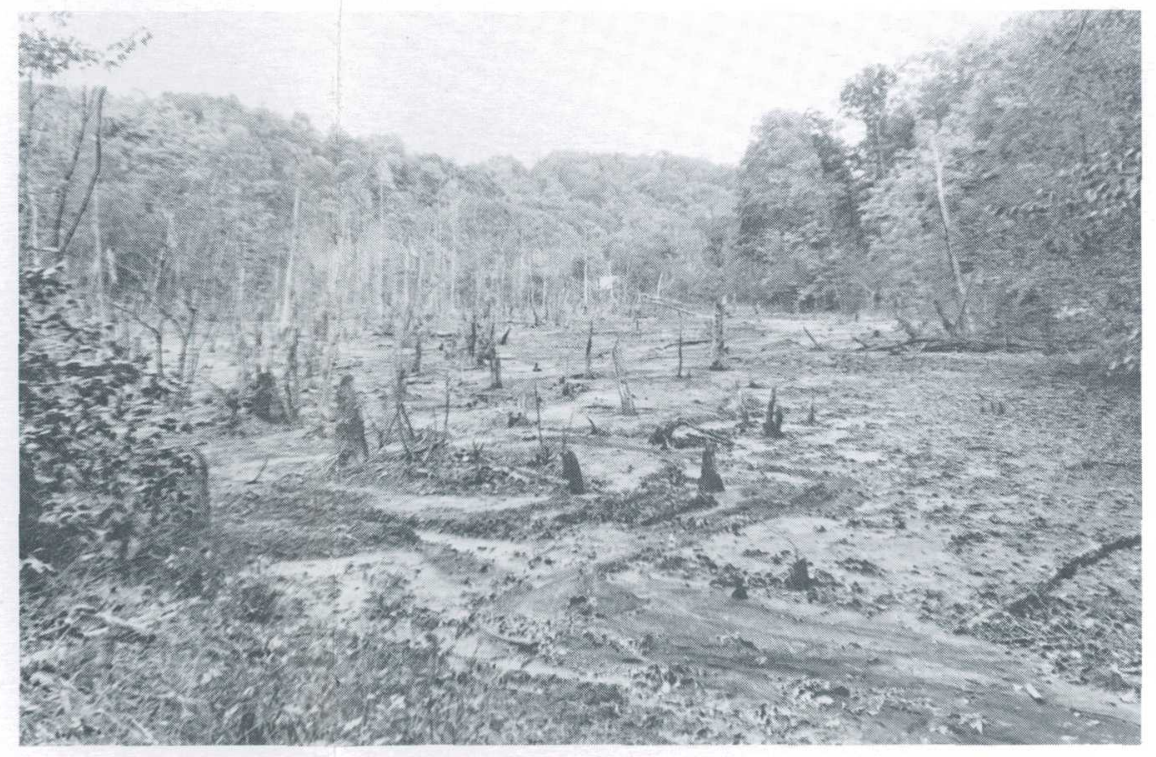

F. Sediment from abandoned surface mine completely filling channel and flood plain of stream, Jackson County, Ohio. 


\title{
1.0 INTRODUCTION--Continued \\ 1.4 Definitions of Terms
}

\section{Terms Used in this Report are Defined}

\author{
Some of the technical terms that appear in other sections of this \\ report are defined below.
}

Bed material consists of loose rock, soil material, and plant and animal remains that may be found at the bottom of a body of water.

Benthic invertebrate is an animal without a backbone that lives on or near the bottom of a body of water. In this report, the term refers only to animals more than 0.0083 inches long.

Bottom material includes all the components of bed material (as defined above) plus any manmade materials that may also be at the bottom of a body of water.

Continuous-record station or site is a site that is instrumented to collect streamflow and (or) waterquality data continuously and systematically over a period of years for use in hydrologic analyses.

Cubic foot per second $\left(\mathrm{ft}^{3} / \mathrm{s}\right)$ is the rate of discharge representing a volume of 1 cubic foot passing a given point during 1 second; it is equivalent to approximately 7.48 gallons per second, 448.8 gallons per minute, or 0.02832 cubic meters per second.

Cubic foot per second per square mile $\left[\left(\mathrm{ft}^{3} / \mathrm{s}\right) \mathrm{mi}^{2}\right]$ is the average number of cubic feet of water flowing per second from each square mile of area drained, assuming that the runoff is distributed uniformly in time and area.

Discharge is the volume of water (or more broadly, volume of fluid plus suspended material) that passes a given point within a given period of time.

Dissolved substance is a substance present in chemical solution. In practice, however, the term includes all forms of matter that will pass through a 0.45-micrometer membrane filter, and thus may include some very small (colloidal) suspended particles. Analyses are performed on filtered samples.

Drainage area of a stream at a specific stream location in that area is measured in a horizontal plane that is enclosed by a topographic divide from which direct surface runoff from precipitation normally drains by gravity into the river above the specified point. Figures of drainage area given herein include all closed basins (noncontributing areas) within the drainage area, unless otherwise noted.

Drainage basin is a part of the land surface that is enclosed by topographic divides and contains a drainage system consisting of a surface stream or a body of impounded surface water and all tributary surface streams and bodies of impounded surface water.

Exceedance probability is the probability of a given amount of flow being equaled or exceeded in any year. It is the reciprocal of recurrence interval.

Gage height (G.H.) is a water-surface elevation above or below an arbitrary gage datum. Gage height is often used interchangeably with the more general term "stage," although gage height is more appropriate when used with a reading on a gage.

Habitat is the place or type of site where a plant or animal naturally or normally lives and grows.

Hydrologic unit is a geographic area representing part or all of a surface drainage basin or distinct hydrologic feature on State Hydrologic Unit Maps as delineated by the Office of Water Data Coordination; each hydrologic unit is identified by an 8-digit number.

Instantaneous discharge is the discharge at a particular instant of time.

Mean discharge is the average of individual average daily discharges during a specified period.

Median is the middle value in a set of data that has been ranked from the highest to lowest.

Micrograms per gram ( $\mu \mathrm{g} / \mathrm{g})$ is a unit expressing the concentration of a chemical element as the mass 
(in micrograms) of the element per unit mass (in grams) of sediment.

Micrograms per liter $(\mu \mathrm{g} / \mathrm{L})$ is a unit expressing the concentration of chemical constituents in solution as mass (in micrograms) of solute per unit volume (liter) of water. One thousand micrograms per liter is equivalent to one milligram per liter.

Milligrams per liter $(\mathrm{mg} / \mathrm{L})$ is a unit for expressing the concentration of chemical constituents in solution. Milligrams per liter represent the mass of solute per unit volume (liter) of water. Concentration of suspended sediment also is expressed in $\mathrm{mg} / \mathrm{L}$, and is based on the mass (dry weight) of sediment per liter of water-sediment mixture.

Partial-record site is a particular site where limited streamflow and (or) water-quality data are collected systematically over a period of years for use in hydrologic analyses.

Sediment is solid material that originates mostly from disintegrated rocks and is transported by, suspended in, or deposited from water; it includes chemical and biochemical precipitates and decomposed organic material, such as humus. The quantity, characteristics, and origin of sediment in streams are influenced by environmental factors, including length and angle of slope, soil characteristics, land use, and quantity and intensity of precipitation.

Specific conductance is a measure of the ability of water to conduct an electrical current. It is expressed in micromhos per centimeter $(\mu \mathrm{mho} / \mathrm{cm})$ at 25 degrees Celsius. Specific conductance is related to the type and concentration of ions in solution and can be used to approximate the dissolved-solids concentration of the water. Commonly, the concentration of dissolved solids (in milligrams per liter) is about 65 percent of the specific conductance (in micromhos). This relation is not constant from stream to stream, and it may vary in the same source with changes in the composition of the water.

Stage-discharge relation is the relation between gage height (stage) and volume of water flowing in a channel per unit of time.

Standard error of estimate (in percent) is a range of error such that a numerical value estimated by a regression equation is within this range at about two out of three times, and is within twice this range about 19 out of 20 times.

Streamflow is the discharge that occurs in a natural channel. Although the term "discharge" can be applied to the flow of a canal, the word "streamflow" uniquely describes the discharge in a stream channel.

Substrate is the physical surface upon which an aquatic organism lives.

Suspended sediment is the sediment that, at any given time, is maintained in suspension by the upward components of turbulent currents, or that is present in suspension as a colloid.

Suspended-sediment concentration is the velocity-weighted concentration of suspended sediment in the sampled zone (from the water surface to a point approximately 0.3 foot above the bed) expressed as milligrams of dry sediment per liter of watersediment mixture $(\mathrm{mg} / \mathrm{L})$. 


\subsection{GENERAL FEATURES \\ 2.1 Geology}

\section{Four Major Rock Units of Pennsylvanian Age Crop Out in Area 11}

\section{Coal seams 1 to 4 feet thick are found in four formations of the Pennsylvanian System that crop out in the area.}

Bedrock is predominantly shale and sandstone of Pennsylvanian age. Most of the coal reserves are in the Pottsville, Allegheny, Conemaugh, and Monongahela Formations and equivalent rocks of the Pennsylvanian System. Coal-bearing strata form bands of differing width that trend northeast to southwest (fig. 2.1-1). The rocks gently dip east-southeast with a slope of about 30 feet per mile. The four major Pennsylvanian formations lie in conformable sequence from west to east (Brant and DeLong, 1960).

Pennsylvanian rocks crop out over the entire study area, except in the western part where the rocks of Early Mississippian age crop out. The strata consist of siltstone, beds of shale and sandstone, and lenses of limestone (Price and others, 1962).
Coal-bearing strata consist of alternating sequences of shale, sandstone, limestone, clay, and bituminous coal. This cyclic repetition of strata is referred to as a cyclothem (Brant and Delong, 1960). (See fig. 2.1-2.)

The major formations range in thickness from 225 feet (Allegheny Formation) to 500 feet (Conemaugh Formation). Generalized stratigraphic columns suggest that the average thickness of each formation is as follows: Pottsville, 256 feet; Allegheny, 212 feet; Conemaugh, 400 feet; and Monongahela, 248 feet (Brant and DeLong, 1960). Coal seams within these formations range in thickness from 1 to 4 feet. The average thickness of a seam is 2.5 feet (fig. 2.1-3). 


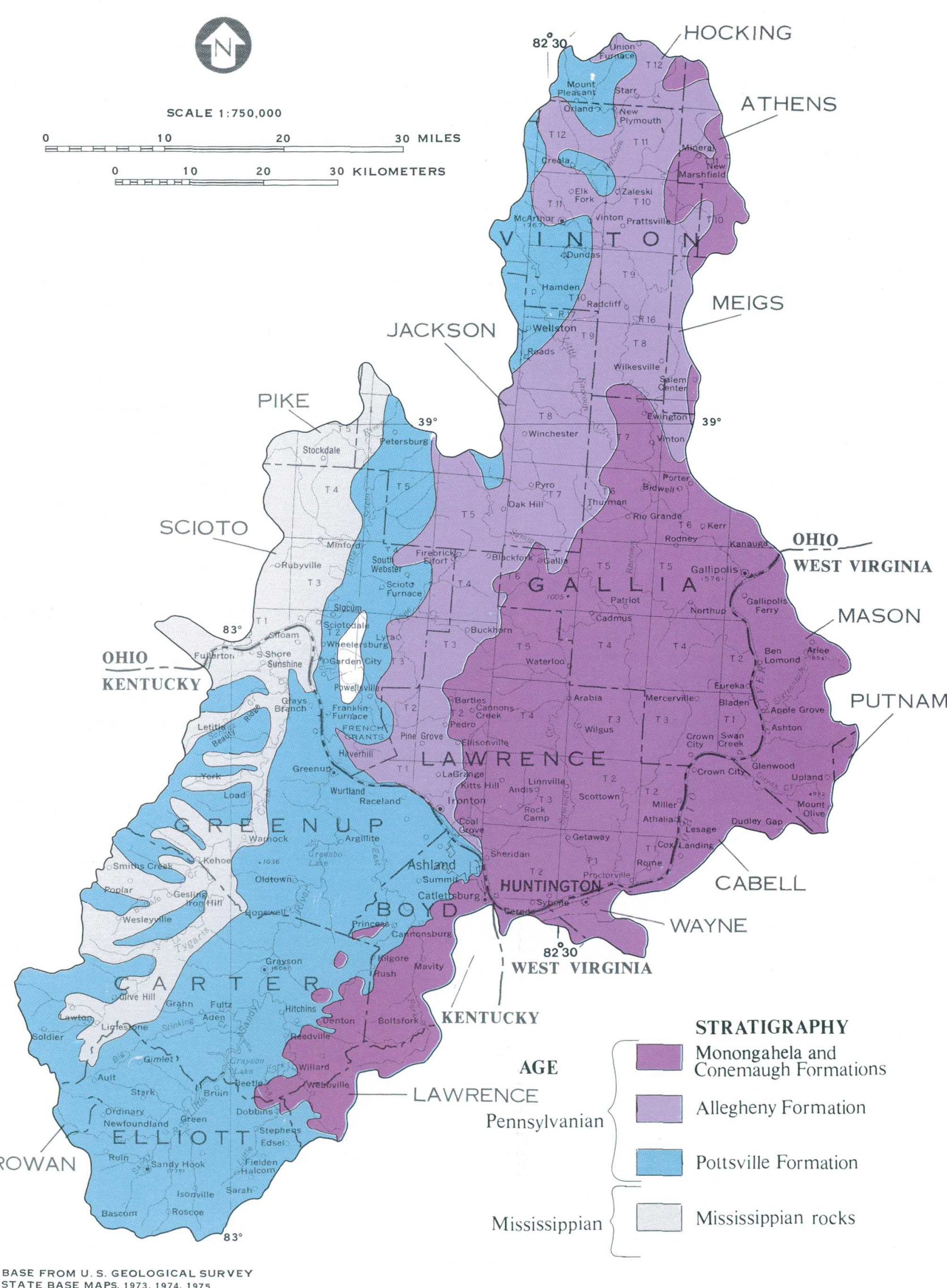

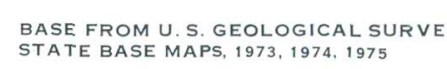

Figure 2.1-1 Geology of Areall (compiled from Price and others, 1962; and Brant, 1956)

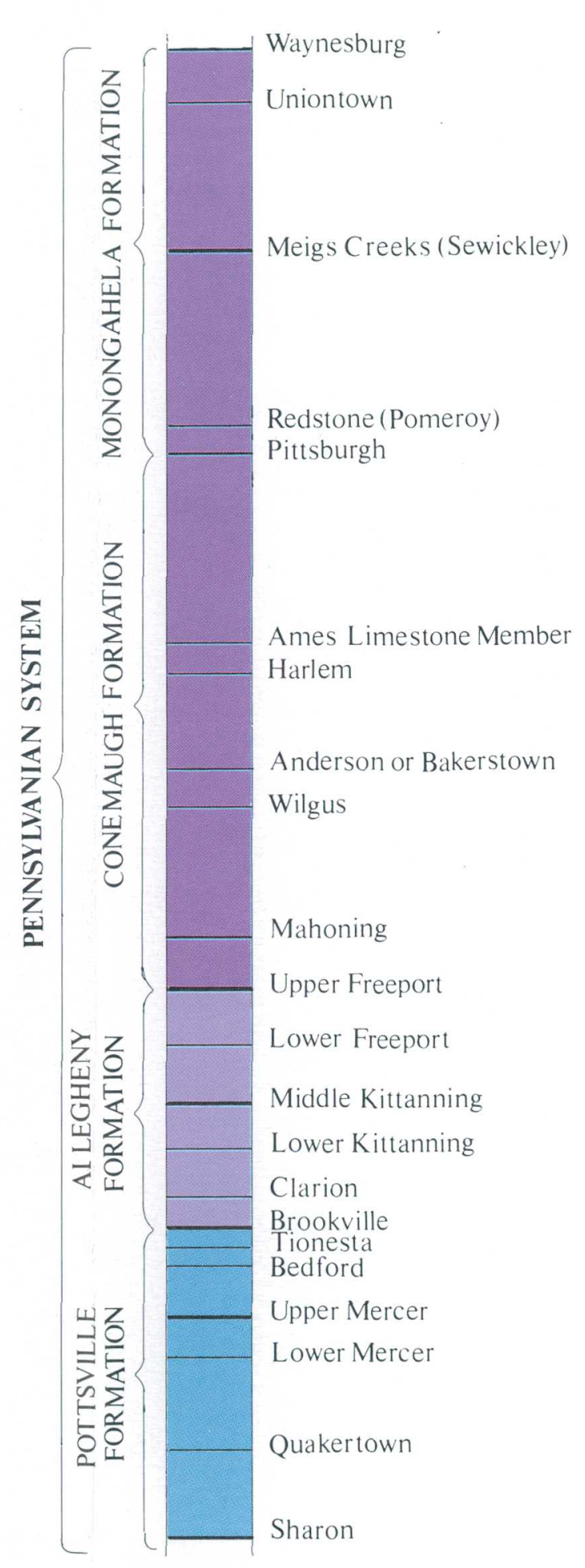

Figure 2 1-3 Coal-beds in the Pennsylvanian System ( Brant and DeLong, 


\subsection{GENERAL FEATURES--Continued \\ 2.2 Surface Drainage}

\section{Area 11 Streams Drain into the Ohio River}

\section{Seven major tributaries of the Ohio River drain Area 11.}

Area 11 includes 3,190 square miles within the Ohio River basin. The Ohio River basin in Area 11 includes part of three states -- Ohio, north of the river, contains 57 percent of the basin; Kentucky, south of the river, 36 percent of the basin; and a small part of West Virginia east of the river contains 7 percent of the basin.

The major Ohio River tributaries in the Ohio part of the area are Raccoon Creek, Symmes Creek, Little Scioto River, Pine Creek, and Indian Guyan Creek. On the Kentucky side of the Ohio River, the major tributaries are the Little Sandy River and Tygarts Creek. The West Virginia part of the area contains no major tributaries of the Ohio River. Figure 2.2-1 shows the location of the streams and their drainage areas.

Drainage-area information is useful in analyzing flow characteristics of streams, designing hydrologic structures, evaluating the availability of water, and predicting floodflows. 

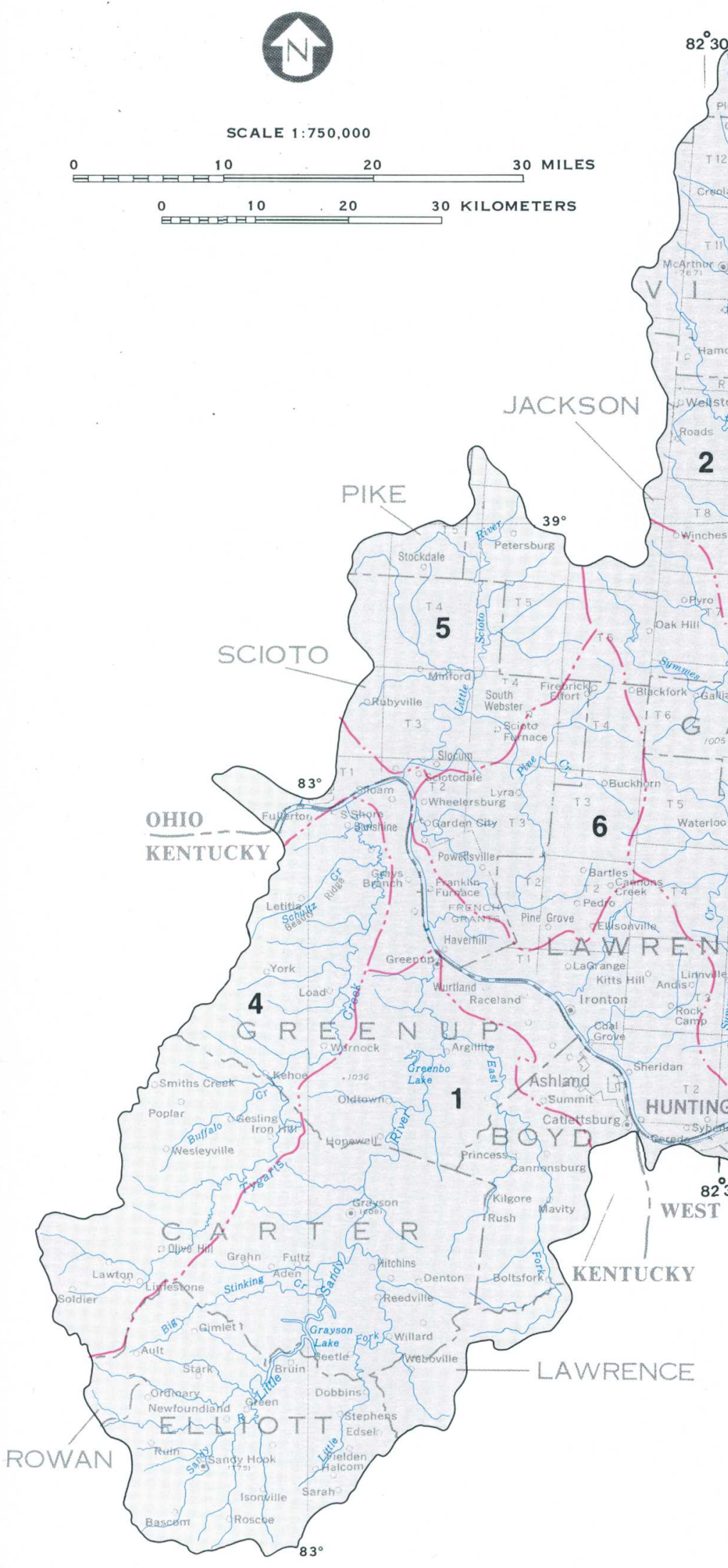

BASE FROM U.S. GEOLOGICAL SURVEY STATE BASE MAPS, 1973, 1974, 1975

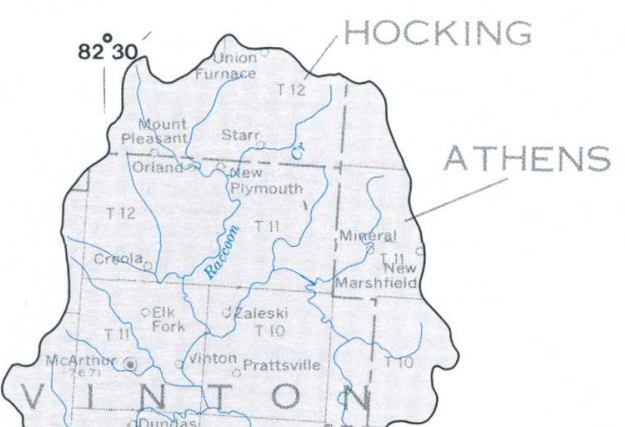

Little Sandy River $(\mathrm{Ky})$

2 Raccoon Creek (Oh) MASON

3 Symmes Creek (Oh) 357

4 Tygarts Creek (Ky) 340

5 Little Scioto River (Oh) 233

6 Pine Creek $\quad(\mathrm{Oh}) \quad 184$

7 Indian Guyan Creek (Oh) 77.1

Data for Ohio from Cross (1967), and for Kentucky, from Kentucky Department of Natural Resources (1965)

Figure 2.2-1 Major drainage basins in Area 11 


\subsection{GENERAL FEATURES--Continued \\ 2.3 Land Use}

\section{Much of the Area is Forested}

\section{Although most of the area is forested, coal mining, agriculture, and urban land uses are found as well.}

Approximately 80 percent of the area is forested. Cropland and pastureland are found mainly along the major tributaries because of the moderately rugged topography. Most urban growth is confined to the wide, flat flood plain of the Ohio River.

The greatest concentration of coal mining is in the Ohio part of the area (fig. 2.3-1); about 95 percent of the mined land in the Ohio part is surface mined. Mining in the Kentucky part, all of which is surface mining, is sparse. There is no known coal mining in the West Virginia part. 


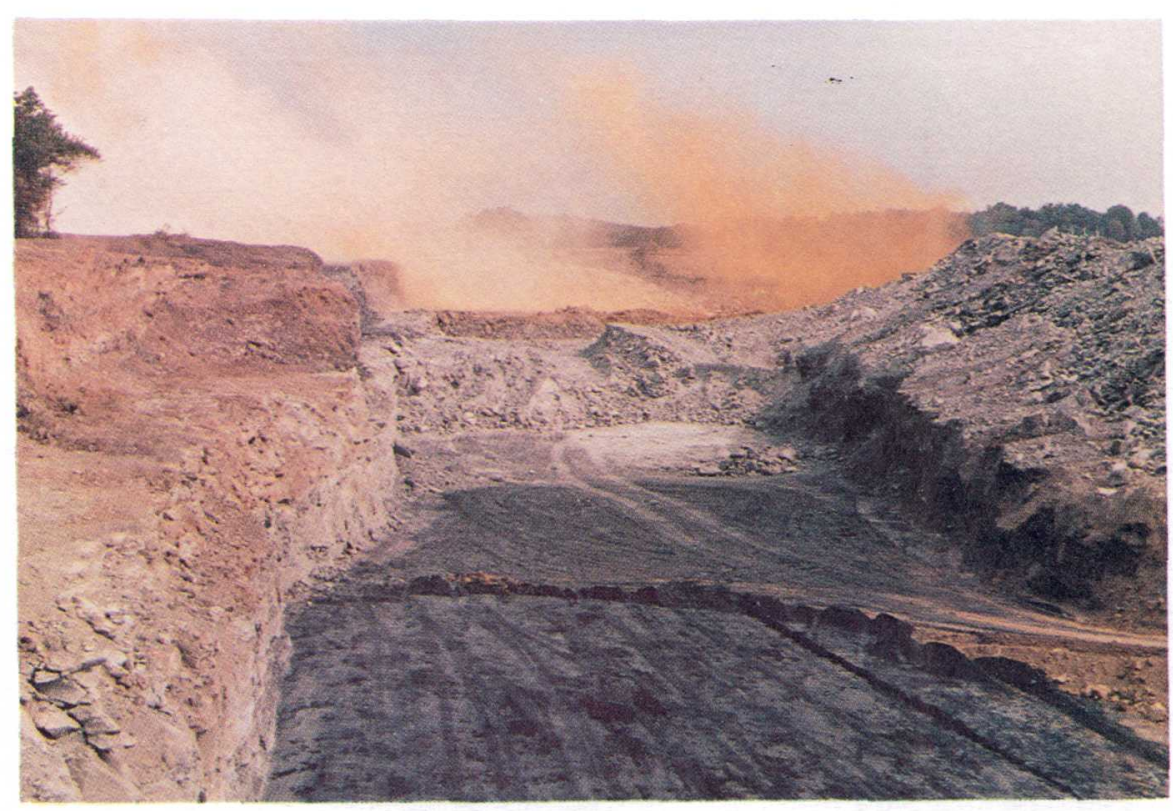

A. Open - pit mine near Mc Arthur, Ohio

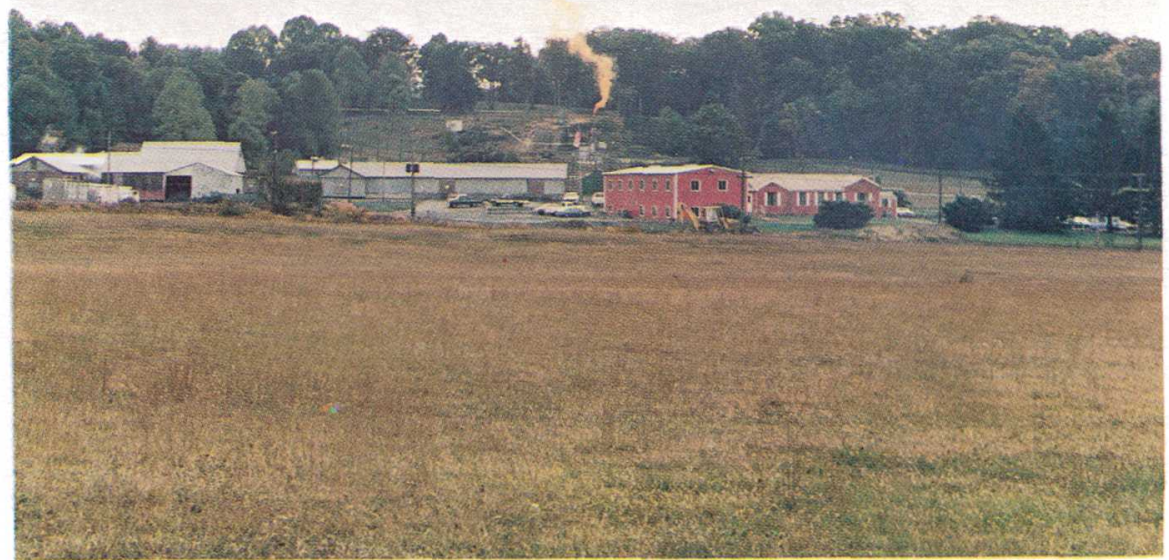

C. Dynamite plant near Zaleski,Vinton County, Ohio
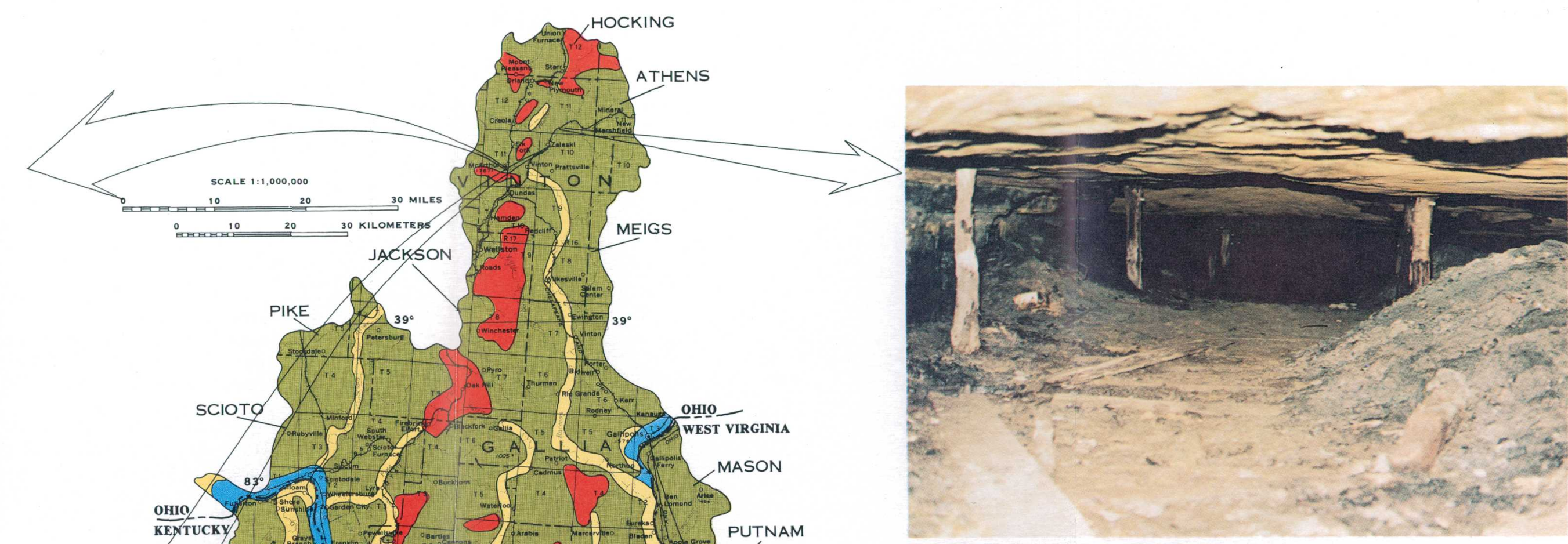

B. Underground mine near Lake Hope,Vinton County, Ohio

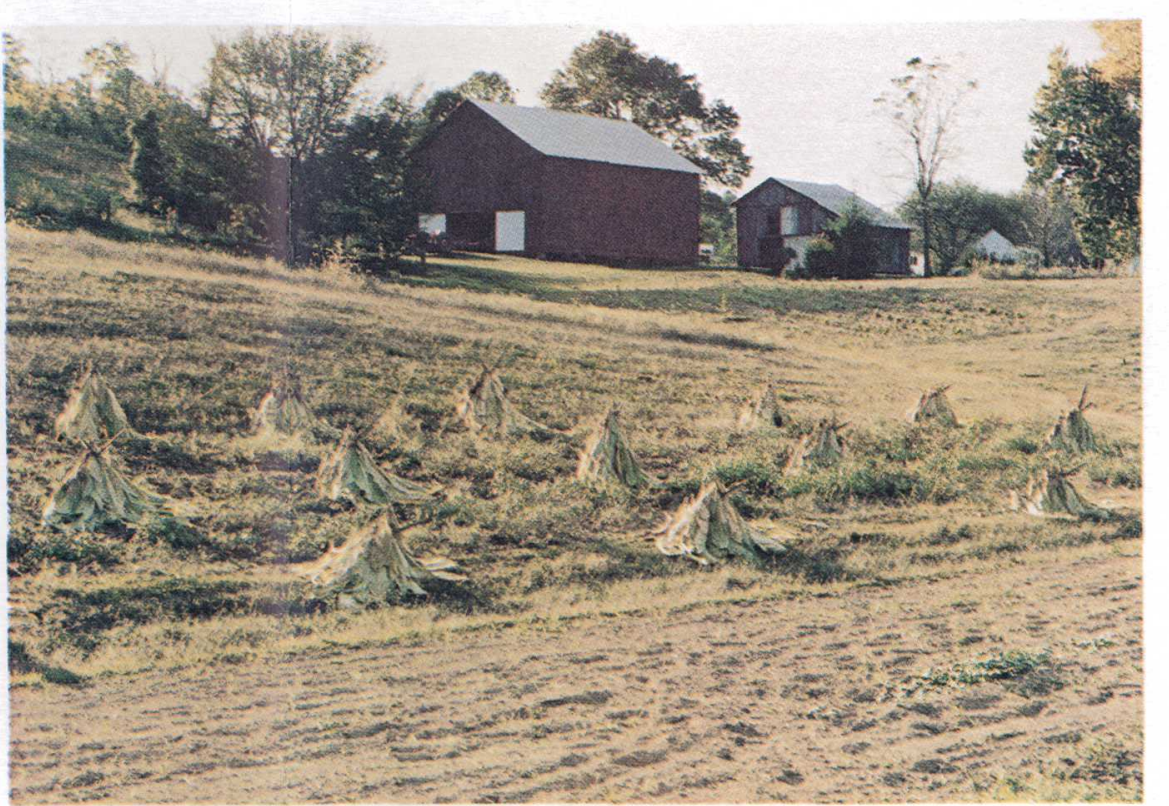

D. Tabacco being harvested in field along Ohio River south of Gallipolis, Ohio

2.0 GENERAL FEATURES (Continued) 2.3 LAND USE 


\subsection{GENERAL FEATURES--Continued \\ 2.4 Coal Mining}

\section{Most Coal Mined in Area 11 is Surface Mined}

\section{Surface mining accounts for approximately 90 percent of the total coal production in Area 11.}

Coal production is concentrated in the northern part of Area 11 and is scattered throughout the southern part. Vinton County, Ohio, is the most productive county (figs. 2.4-1 and 2.4-2).

More than 90 percent of the coal is from surface mines. Before the 1940's, much of the coal was mined underground (Collins, 1976). As mining technology developed, surface mining became more economical than underground mining (fig. 2.4-1).

Coal was first mined in Area 11 in the mid-1700's, but production was not recorded until around 1800 (Collins, 1976). A summary of coal production from 1851 to 1979 in Vinton County, Ohio, is shown in figure 2.4-2. Coal produced in Area 11 usually is loaded onto barges and shipped down or up the Ohio River (fig. 2.4-3).

Some of the coal mined in the area is transported to electric powerplants on the Ohio River. For example, coal is brought directly to the James Gavin Power Plant on the Ohio River near Addison in Gallia County, Ohio (fig. 2.4-4) from the coal fields of southeastern Ohio by a conveyor belt many miles long. Coal is stockpiled between the two cooling towers. 

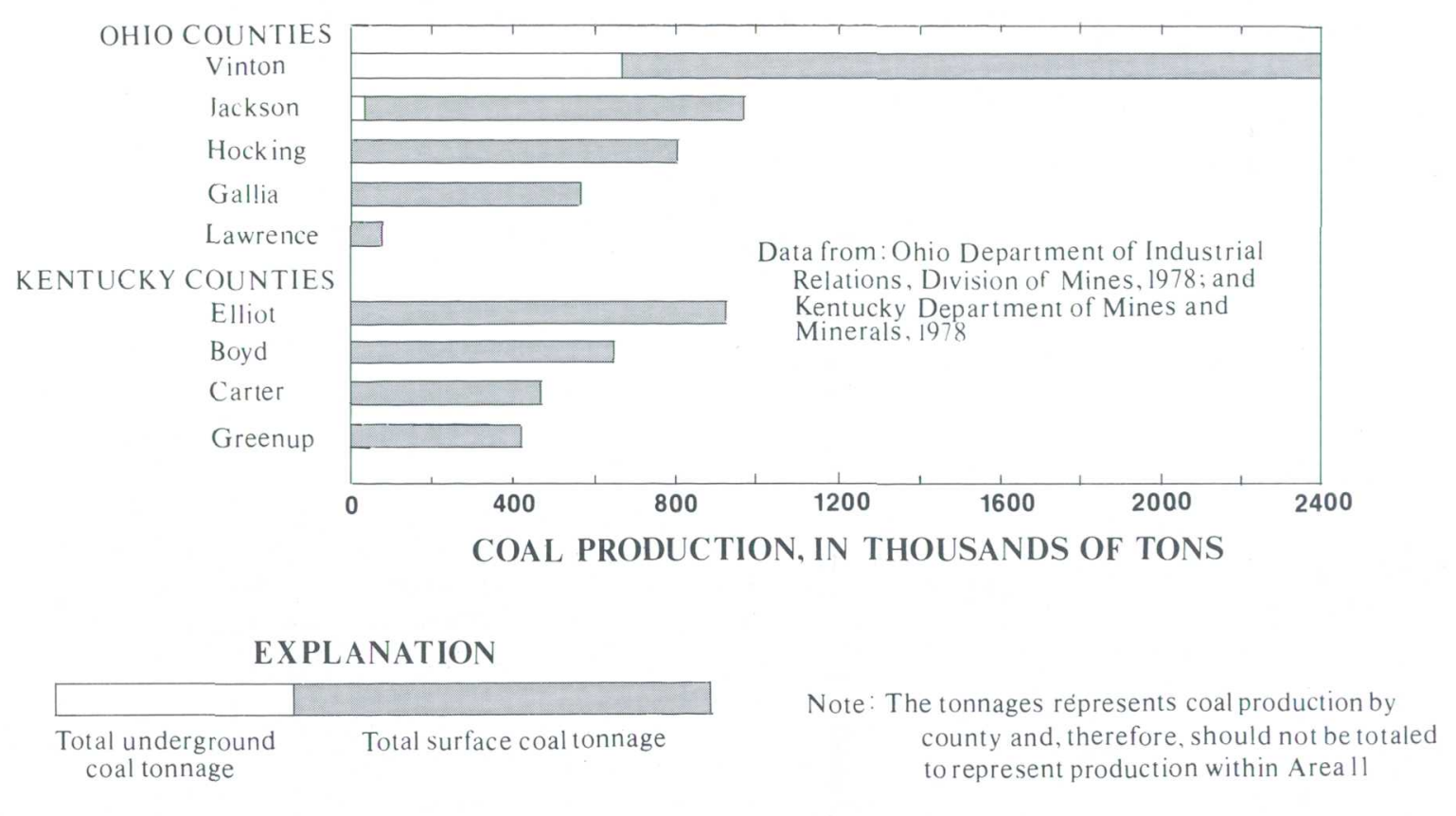

Figure 2.4-1 1978 coal production from underground and surface mines in Area 11

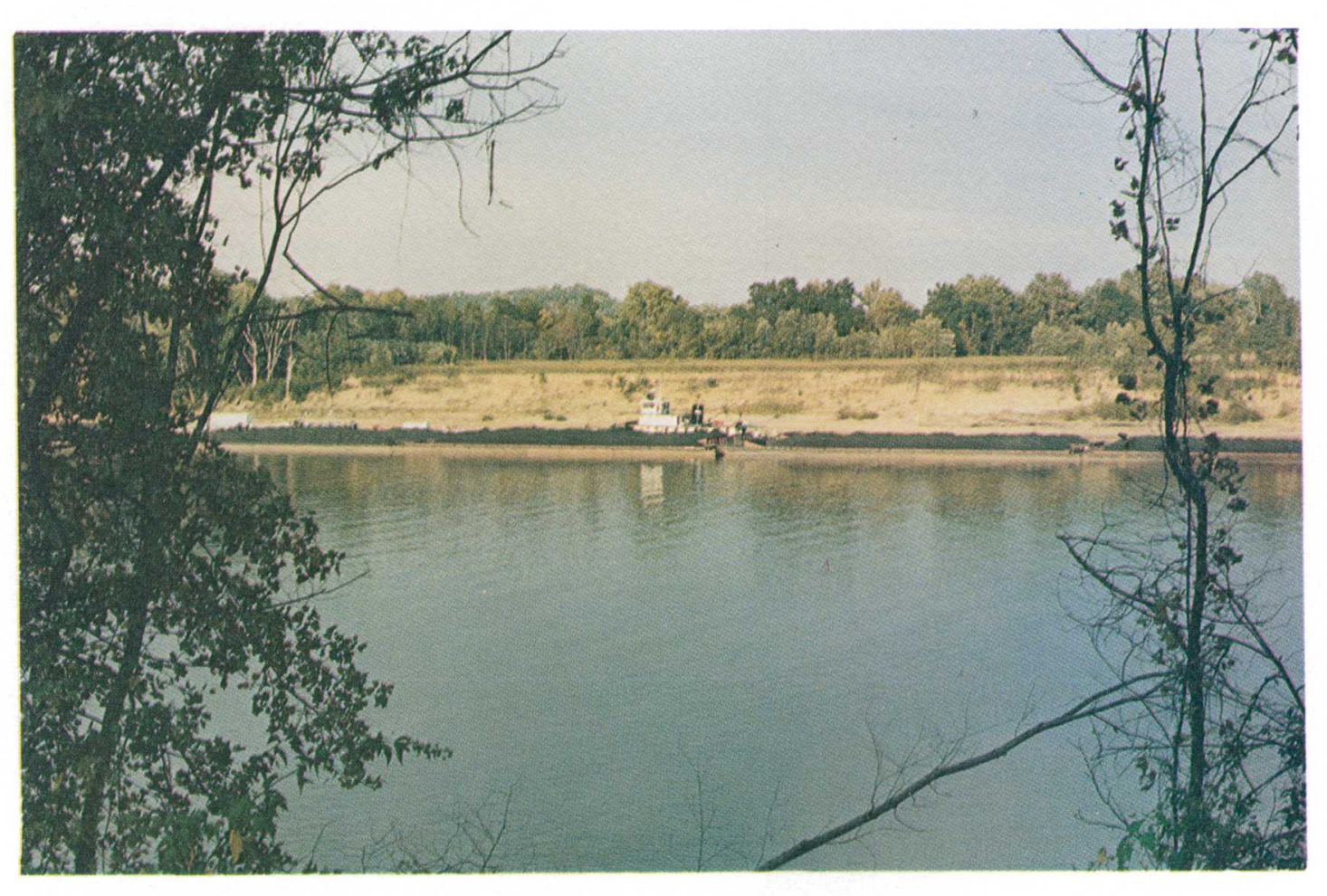

Figure 2.4-3 Coal barges on Ohio River near Gallipolis, Ohio (view looking east)

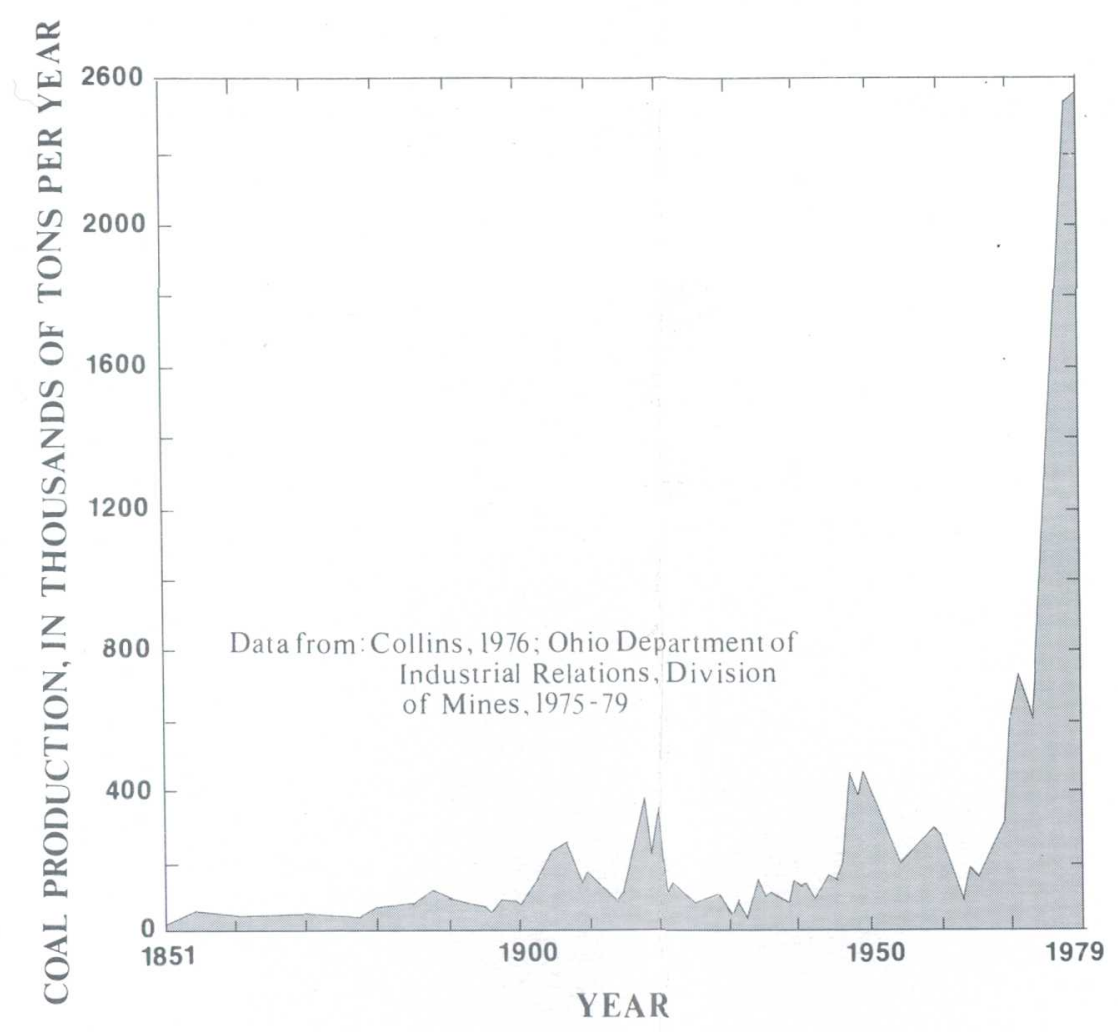

Figure 2.4-2 Coal production in Vinton County, Ohio 1851-1979

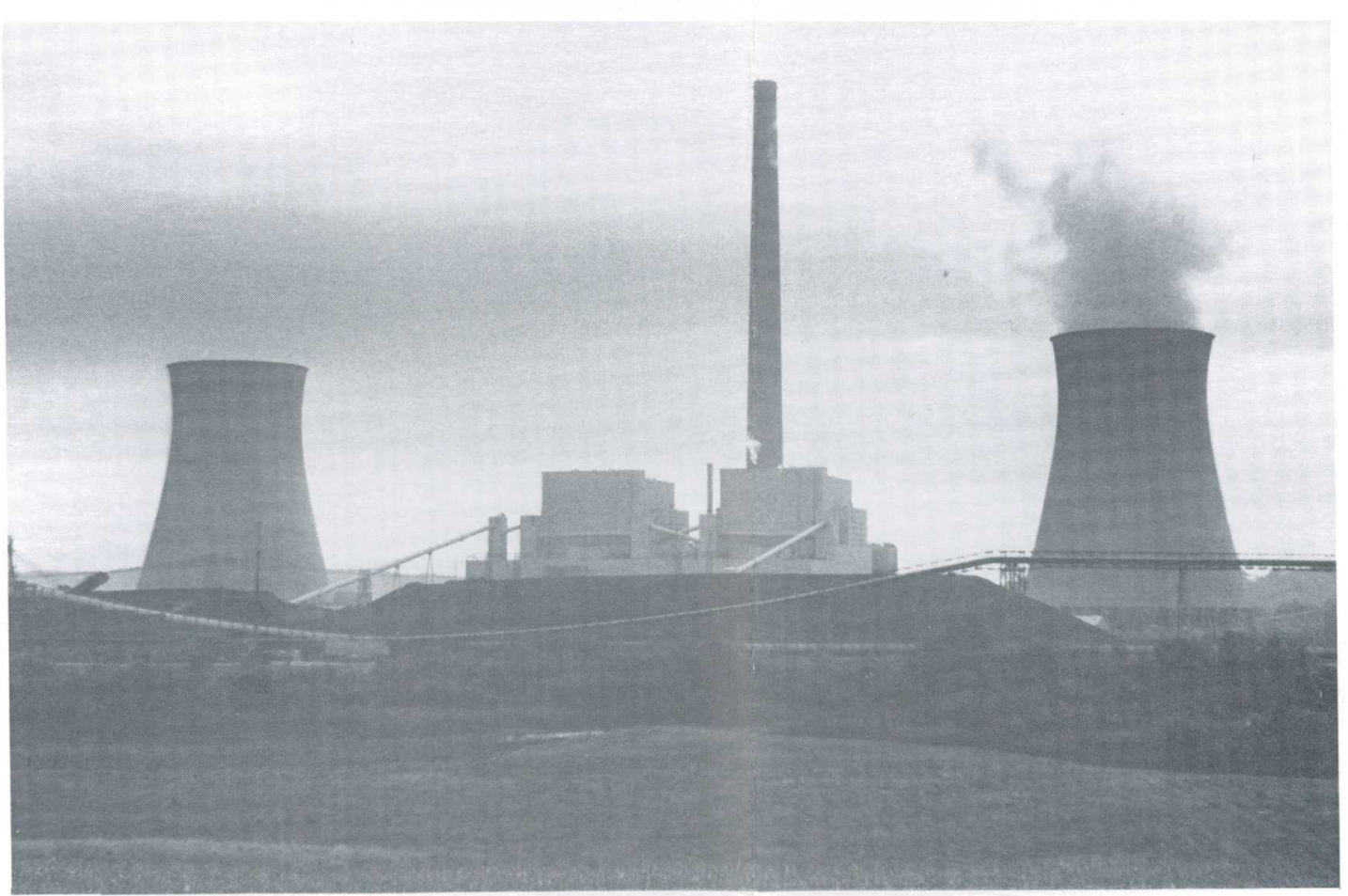

Figure 2.4-4 James Gavin Power Plant near Addison (Gallia County).Ohio. 


\subsection{GENERAL FEATURES--Continued 2.5 Soils}

\section{Acidic Soils Predominate}

\section{Most soils are derived from siltstone, sandstone, and shale.}

Many of the soils in Area 11 have developed from rocks composed of sandstone, shale, or siltstone. Hilltop soils derived from sandstone and shale are shallow to moderately deep and acidic $(\mathrm{pH}$ from 4.5 to 5.0). Because most of these soils are on slopes too steep for cultivation, their use is restricted to forest and pasture. Erosion is a problem where vegetation has been stripped from the slopes.

Soils in most stream valleys are derived from sandstone, shale, siltstone, and small amounts of limestone. They are characterized by low natural fertility and moderate to high acidity ( $\mathrm{pH}$ from 4.5 to 6.5). These valley soils are cultivated to some extent despite some erosion problems on slopes. General farming, dairying, and tobacco production are the most common agricultural activities in the valleys.
In a small part of Area 11 near its western edge (soil group 25, fig. 2.5-1), soils are derived from limestone and dolomite washed down from the glaciated area. They are moderate to high in natural fertility, are variable in concentration of organic matter and in $\mathrm{pH}$ (6.5 to 8.5), and are suitable for farming.

The distribution of the soils is shown in a generalized soils map (fig. 2.5-1). The names and descriptions of the soil associations are given in table 2.5-1.

Additional information on soils can be obtained from the Ohio Department of Natural Resources, Division of Lands and Soil, and from the U.S. Department of Agriculture, Soil Conservation Service, in Ohio, Kentucky, and West Virginia. 


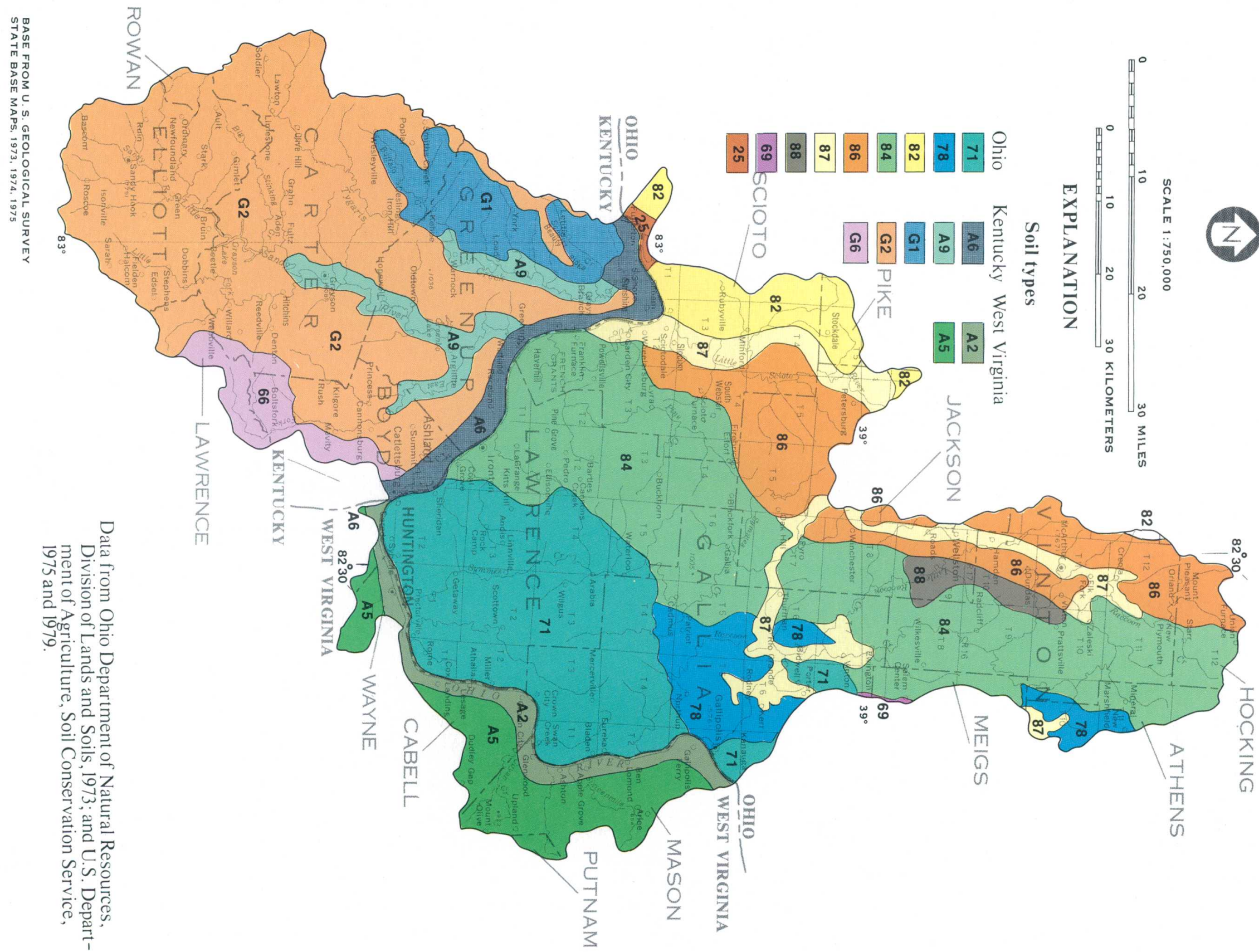

Table 2.5-1.--Description of soils in Area 11

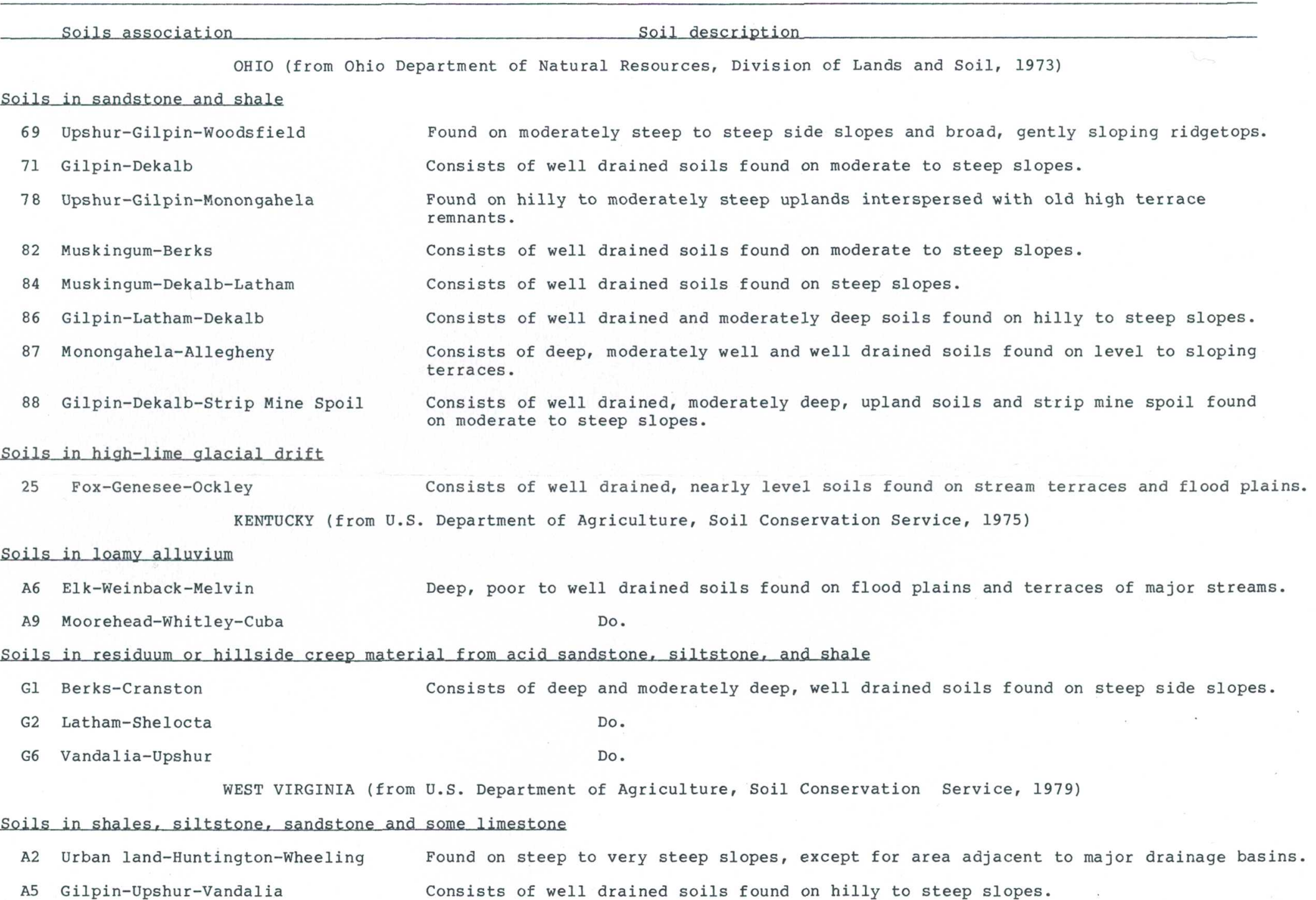




\subsection{GENERAL FEATURES--Continued \\ 2.6 Precipitation}

\section{Average Annual Precipitation Ranges from 39 to 45 Inches}

\section{Precipitation ranges from 39 inches per year in the north to 45 inches per year in the south; precipitation is usually heaviest during the spring and summer.}

The area lies in the path of moisture-laden, low-pressure systems that move up the Ohio River from the Gulf of Mexico. Average precipitation from north to south ranges from 39 to 45 inches (fig. 2.6-1). Precipitation is heaviest from April to September and lightest in autumn and the early winter months. Annual snowfall averages 20 to 25 inches.

A typical yearly precipitation pattern for a precipitation station in Area 11 is shown in figure 2.6-2. This precipitation station, located at Lloyd Greenup Dam in Kentucky, is near the center of the area. Measurable precipitation falls about 130 days of the year. Heavy rains that affect small tributaries generally are the result of local thunderstorms.

Additional information on precipitation and climate may be obtained by writing to the National Climatic Center, Ashville, N.C. 28801, or by contacting any National Weather Service office near the area. The locations of National Weather Service precipitation stations in Area 11 are shown in figure 2.6-3. 


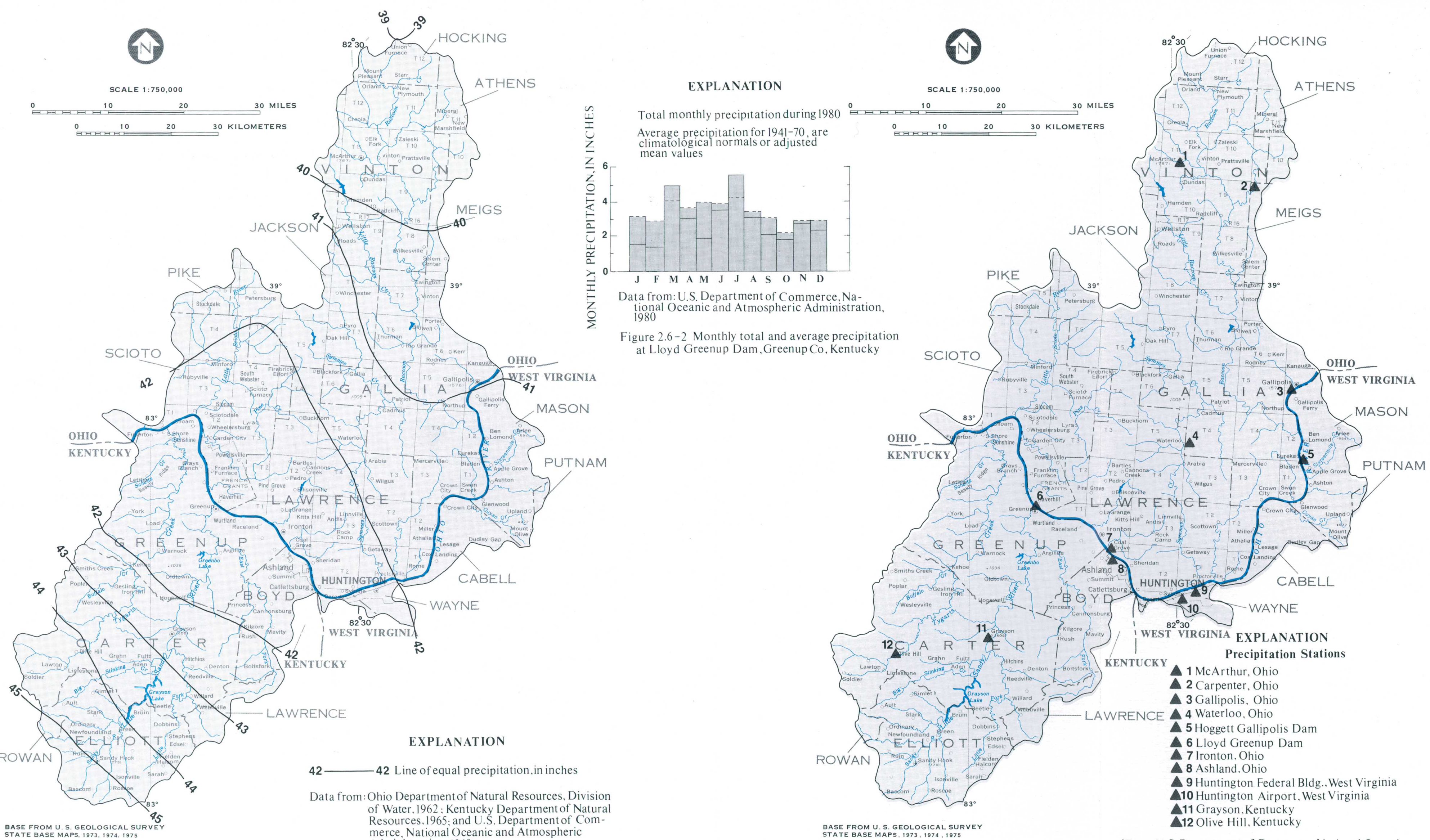

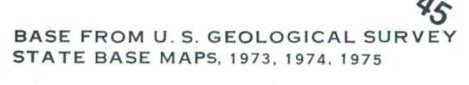

Figure 2.6-1 Average annual precipitation Rerce. National Oceanic and Atmospheric merce. National Ocea
Administra ion. 1969 .
BASE FROM U. S. GEOLOGICAL SURVEY
STATE BASE MAPS. 1973, 1974,1975

Figure 2.6-3 Precipitation net work
(From U.S. Department of Commerce, National Oceanic and Atmospheric Admistration, 1980) 


\subsection{SURFACE-WATER QUANTITY}

3.1 Hydrologic Network

\section{Information on Surface Water Available for 69 Stream Locations}

\section{The surface-water data-collection network was expanded to meet the need for additional hydrologic data.}

The U.S. Geological Survey maintains a nationwide system of continuous and partial-record sites to provide streamflow and water-quality data for water-resources appraisals, and to establish the baseline conditions of the Nation's water.

A partial-record site is a site where limited streamflow, sediment, and (or) water-quality data are systematically collected.

A continuous-record station or site is a site instrumented to collect streamflow, sediment, and (or) water-quality data continuously.

The hydrologic-data collection network in Area 11 was modified and expanded to 53 partial-record sites and 16 continuous-record stations to meet the needs for hydrologic data dictated by the Surface Mining Control and Reclamation Act of 1977 (Public Law 95-87).
Data are available for 69 sites through water year 1981. The locations of all 69 sites are shown in figure 3.1-1. Details on the period of record and the types of data available are given in section 7.1.

Statistical analyses of streamflow were done for 10 of the 16 continuous-record stations. These were the only stations that had the necessary amount of record for analysis of all Area 11 streams. Stations 57,58 , and 59, which are Ohio River sites, were excluded from surface-water statistical analysis because the Ohio River receives drainage from outside Area 11. Low-flow statistics also were available for three partial-record sites.

Data for all sites in Area 11 can be obtained from the U.S. Geological Survey's annual water-resources data reports (1979-81) for Ohio, Kentucky and West Virginia, and from computer storage through $\mathrm{Na}$ tional Water Data Exchange (NAWDEX). 


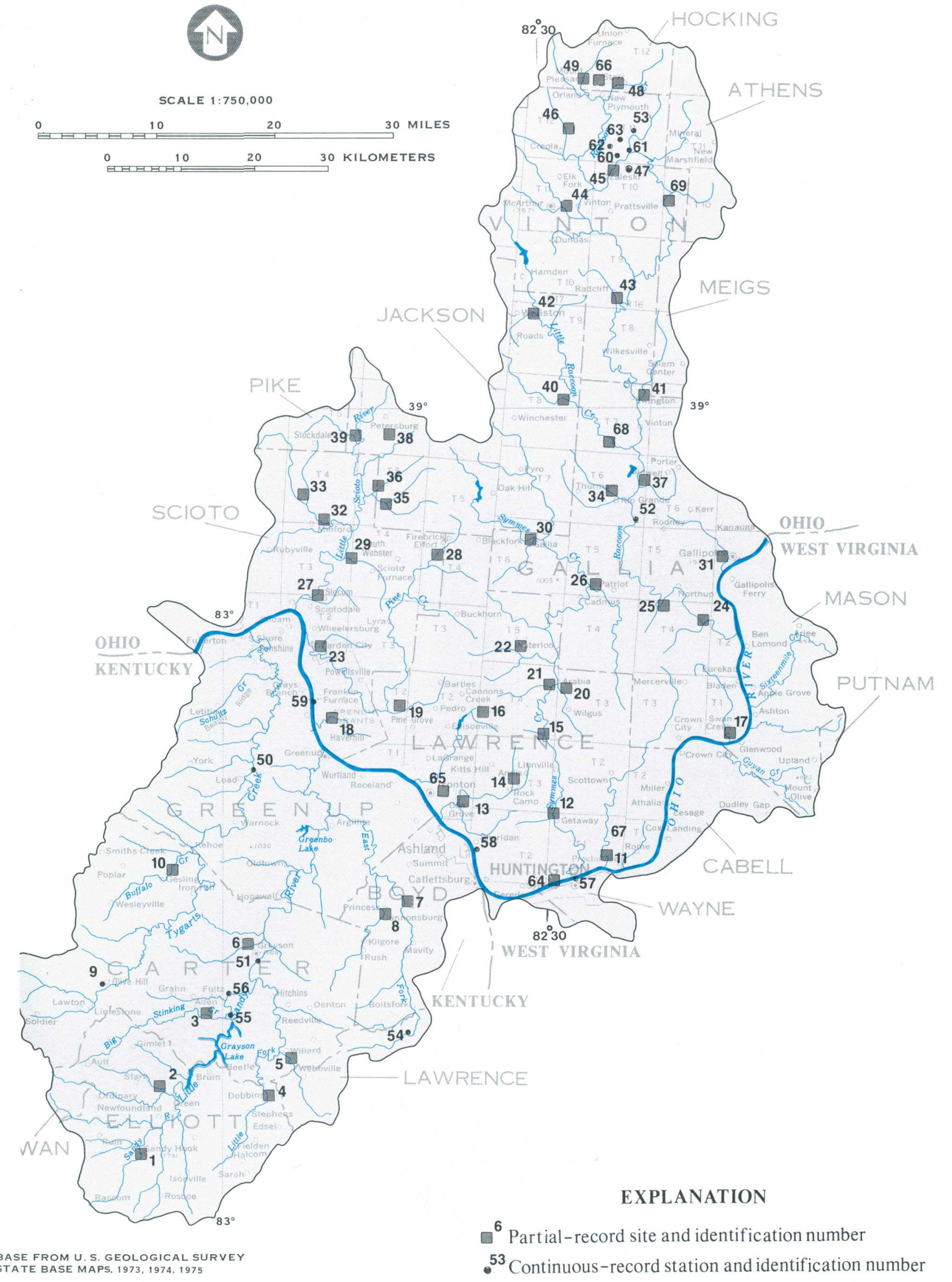

Figure 3.1-1 Hydrologic network 


\subsection{SURF ACE-WATER QUANTITY--Continued 3.2 Streamflow Variability}

\section{Streamflow Varies Seasonally}

\section{Variations in precipitation and evapotranspiration cause seasonal fluctuations in streamflow.}

Streamflow is one component of the hydrologic cycle, which is illustrated in figure 3.2-1. Evapotranspiration, temperature, and rainfall vary from season to season and the resulting streamflow varies seasonally.

Figure 3.2-2 shows the mean monthly discharges for 1 year at two typical gaging stations in Area 11. The hydrograph illustrates typical characteristics of the yearly stream cycle, as explained in table 3.2-1. Because of local thunderstorm activity, streams do not always follow the typical streamflow pattern. For example, site 52 had an increase in streamflow in July, whereas site 9 showed no appreciable increase in streamflow for July.

Streamflow varies throughout Area 11 due to differences in mean annual precipitation and, to some extent, geology. In the Kentucky part of Area 11 , sites 9,50 , and 54 have higher mean annual discharges per square mile than sites $47,52,53$, and 62 in Ohio. The average annual precipitation in the
Ohio part of Area 11 is about 40.5 inches, whereas in the Kentucky part, it is about 43.5 inches.

Mean annual discharge per square mile has been determined for 10 sites in Area 11 (section 7.2). The mean annual discharge for each of these sites ranges from 1.12 cubic feet per second per square mile (site 52) to 1.47 cubic feet per second per square mile (site 9). The mean annual discharge for all 10 sites is 1.23 cubic feet per second per square mile. Flow is regulated at three of these sites $(51,55$, and 56$)$.

The mean annual flow of streams is dependent on drainage area, soils, area of lakes, ponds, and forests, and slope. The most important factor is the drainage area. The equation $\mathrm{Q}_{\mathrm{a}}=1.20 \mathrm{~A}^{1.01}$ may be used to estimate the mean annual flow of ungaged streams in Area 11, where $Q_{a}$ is the mean annual discharge, in cubic feet per second, and $A$ is the drainage area in square miles (fig. 3.2-3). The equation is based on data from the 10 gaging stations for which mean annual discharge has been determined.

Table 3.2-1 Explanation of typical streamflow pattern, by month

\begin{tabular}{|c|c|}
\hline Month (s) & Typical characteristics \\
\hline October & Average or below average precipitation results in low flow. \\
\hline $\begin{array}{l}\text { November and } \\
\text { December }\end{array}$ & $\begin{array}{l}\text { Evapotranspiration decreases as temperature decreases; streamflow increases } \\
\text { slightly in December. }\end{array}$ \\
\hline $\begin{array}{l}\text { January and } \\
\text { February }\end{array}$ & $\begin{array}{l}\text { Alternate freezing and thawing cause considerable fluctuation in streamflow } \\
\text { throughout this period. }\end{array}$ \\
\hline $\begin{array}{l}\text { March and } \\
\text { April }\end{array}$ & Flow increases considerably, owing to spring thaws, snowmelt, and rains. \\
\hline $\begin{array}{l}\text { May and } \\
\text { June }\end{array}$ & $\begin{array}{l}\text { Growing season begins and water demanos by plants and increase; evapotrans- } \\
\text { piration increases and stream-flow decreases. }\end{array}$ \\
\hline $\begin{array}{l}\text { July and early } \\
\text { August }\end{array}$ & Streamflow is replenished somewhat by local thunderstorms. \\
\hline $\begin{array}{l}\text { Late August and } \\
\text { September }\end{array}$ & Flow recedes. Ground-water discharge is the main source of streamflow. \\
\hline
\end{tabular}




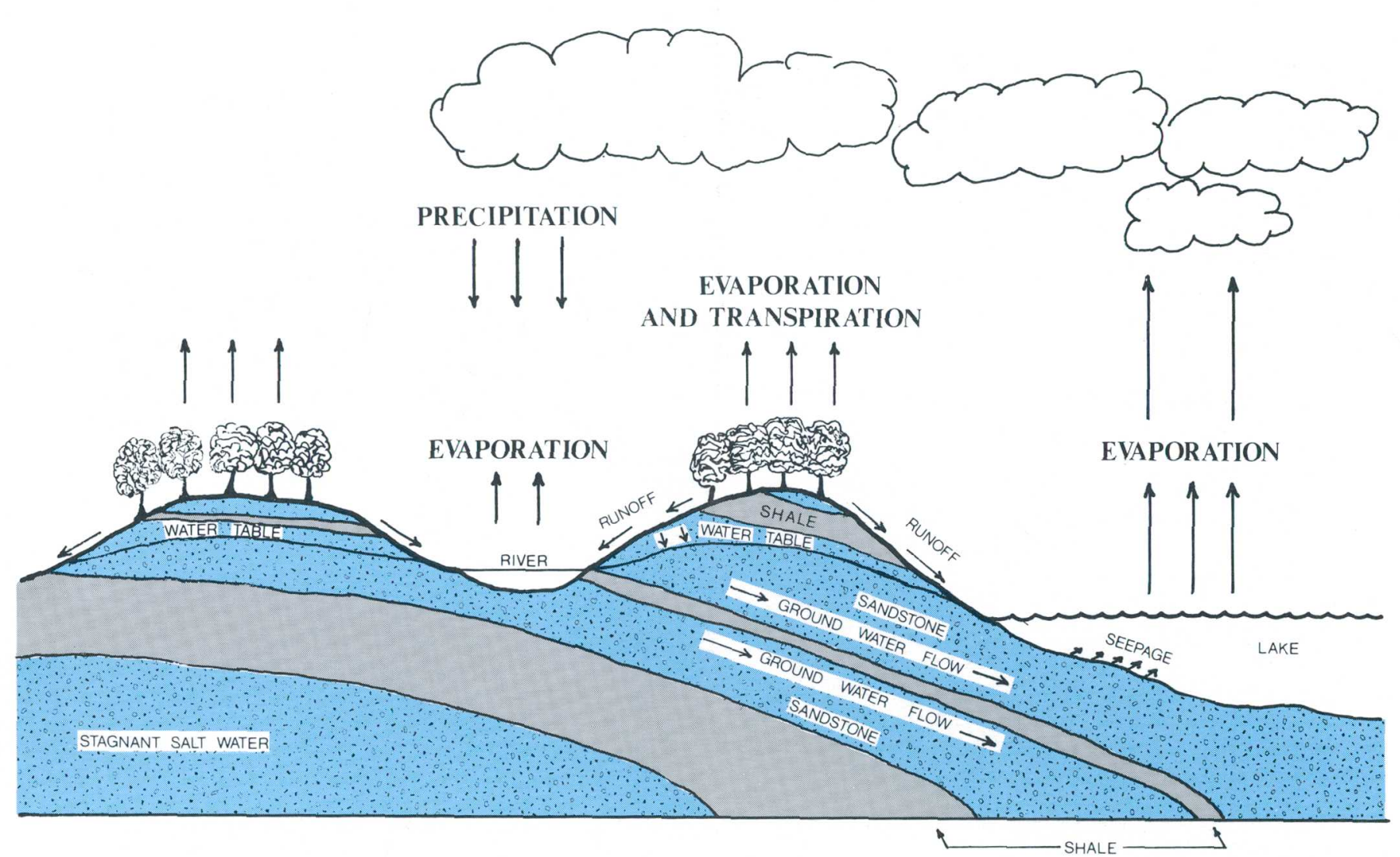

Figure 3.2-1 Hydrologic cycle (modified from Landers, 1976).

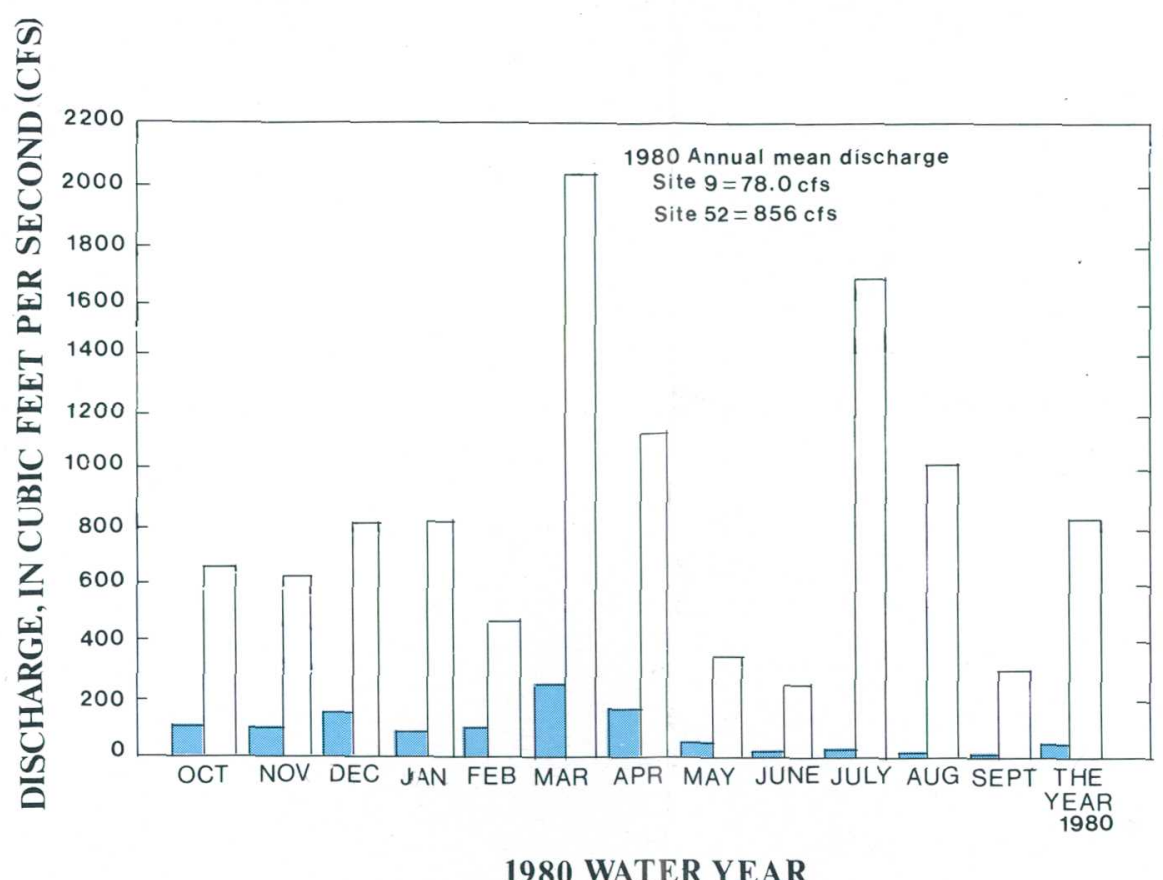

1980 WATER YEAR

Average discharge for site 9. Tygarts Creek at Olive Hill, Kentucky (drainage area $=59.6$ square miles)
Average discharge for site 52 , Raccoon Creek at Adamsville, Ohio
(drainage area $=585$ square miles) Figure 3.2-2 Seasonal pattern of streamf low for 1980 water year (U.S. Geological
Survey,1981)

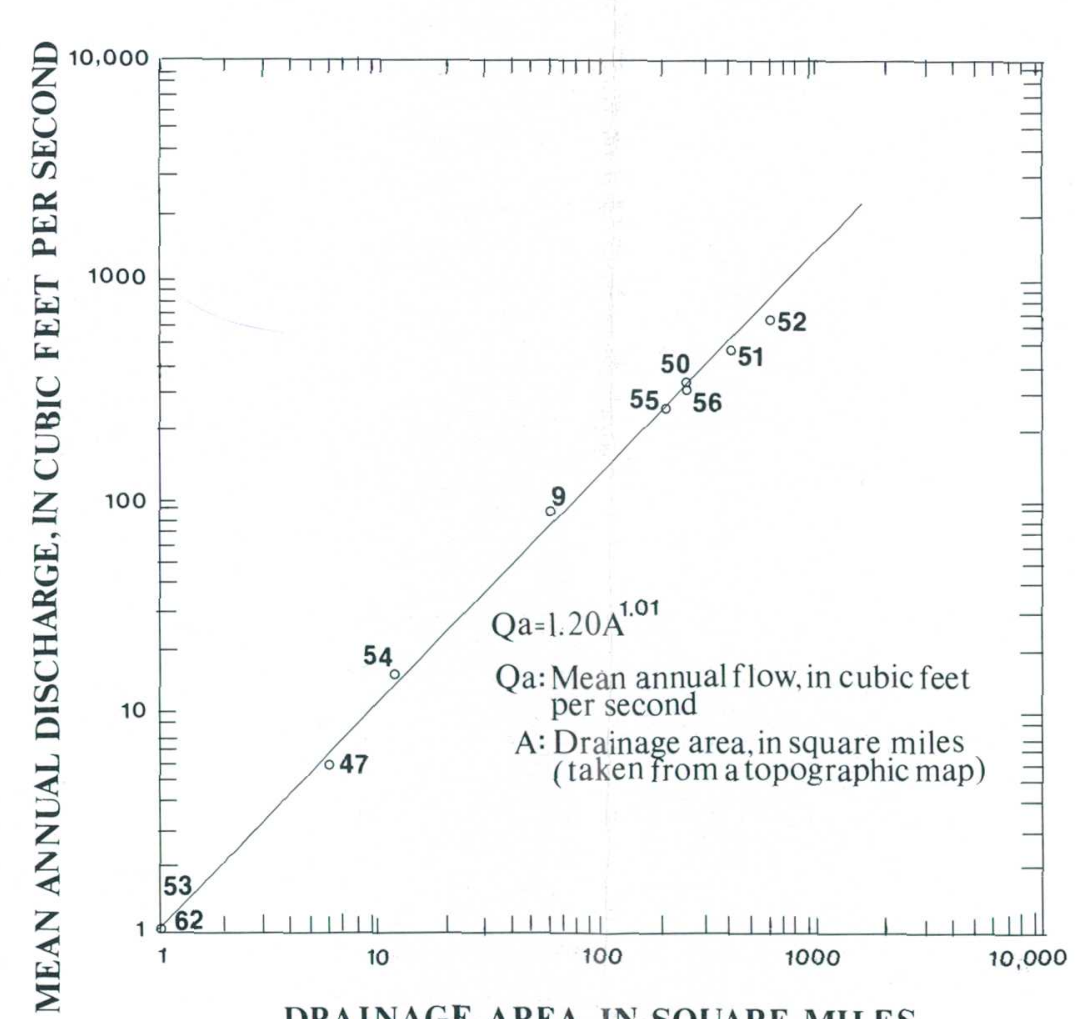

Figure 3.2-3 Mean annual flow in Areall 


\title{
3.0 SURFACE-WATER QUANTITY--Continued \\ 3.3 Low Flow
}

\section{Low-Flow Data Crucial for Water-Quality Management}

\author{
Low flow is poorly sustained in Area 11.
}

Information on the low-flow characteristics of a stream is vital for maintaining adequate streamflow for aquatic life, for esthetics, and for a variety of uses related to human activity. Low flow at any location depends in part on (1) precipitation in the drainage basin; (2) the temperature regime, which controls the storage of water and influences evapotranspiration rates; and (3) the soil and geologic characteristics of the drainage basin that control the recharge and discharge of ground water (Riggs, 1972).

In general, the low flows of streams in Area 11 are poorly sustained. Most of the streams that drain less than 100 square miles approach zero flow during the low-flow season, which is normally from late June through October. The low-flow frequency curve $^{1}$ for site 52, Raccoon Creek at Adamsville, Ohio, is shown in figure 3.3-1. The 7-day, 10-year low flow ${ }^{2}$ (7-day Q10) is 3.5 cubic feet per second according to this frequency curve.

The 7-day Q10 per square mile has been determined for eight of the ten continuous record stations and three partial-record sites in Area 11 (section 7.2; fig. 3.3-2). Three of the continuous-record stations are on the Little Sandy River in Kentucky and are regulated at Grayson Dam; the 7-day Q10 per square mile for these stations ranges from 0.045 to 0.068 . The 7-day Q10 is zero for four of the nonregulated sites. The 7-day Q10's per square mile for the remaining nonregulated sites ranged from 0.001 to 0.008 .

\footnotetext{
${ }^{1}$ A low-flow frequency curve is a graph used to determine the magnitude of a selected frequency of annual minimum flow for a given number of consecutive days.

${ }^{2}$ The 7-day, 10-year low flow is the lowest average rate of flow for seven consecutive days to which streamflow can be expected to decline on the average of 1 year out of 10 .
} 
PERCENTAGE OF TIME DISCHARGE WAS LOWER OR EQUALED (EXCEEDENCE PROBABILITY)

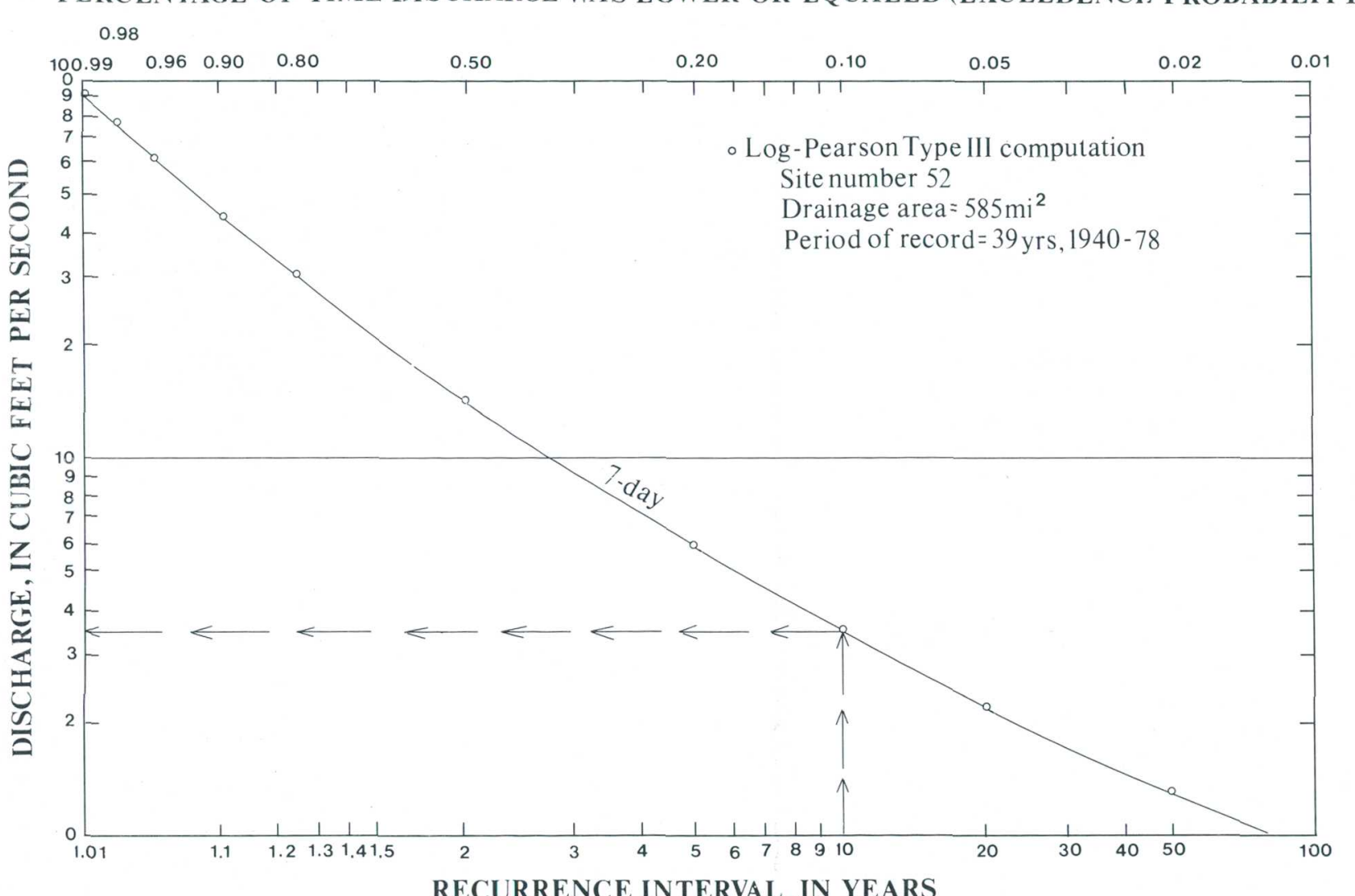

RECURRENCE INTERVAL, IN YEARS

Figure 3.3-1 7-day low-flow frequency curve for site 52. Racoon Creek at Adamsville, Ohio.

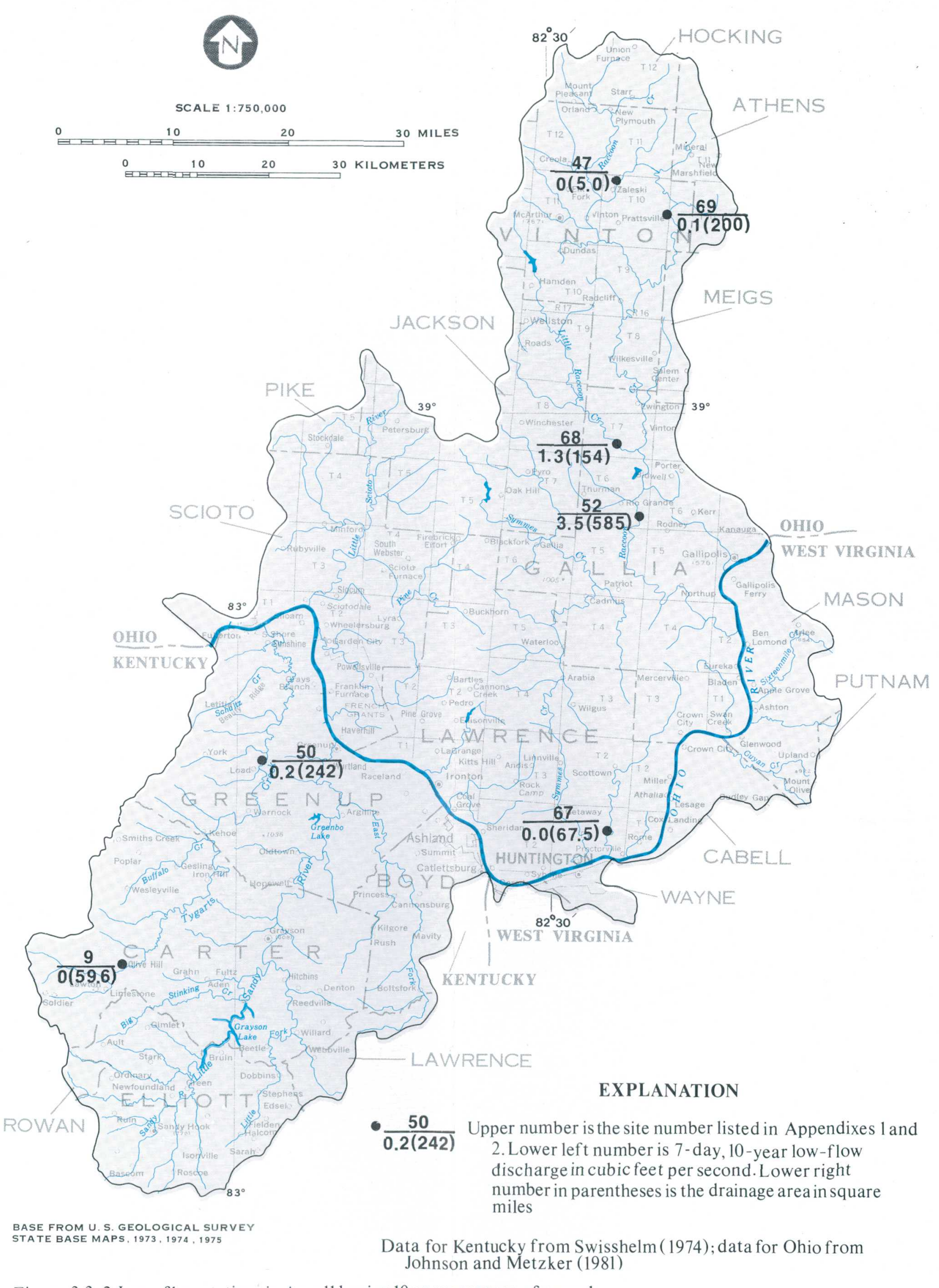

Figure 3.3-2 Low-flow stations in Area 11 having 10 or more years of record. 


\subsection{SURFACE-WATER QUANTITY--Continued \\ 3.4 Flood-Prone Areas}

\section{Information on Flood-Prone Areas is Available}

\section{Flood-prone-area maps can be obtained from the U.S. Geological Survey and from State flood-insurance coordinators.}

Published flood-prone-area maps for Area 11 are shown in figure 3.4-1. Part of a flood-prone-area map is shown in figure 3.4-2. These maps can be obtained from the U.S. Geological Survey offices in Ohio, Kentucky, and West Virginia, and from the Federal Emergency Management Agency (FEMA), whose State flood-insurance coordinators can provide detailed flood information for many areas.

The area affected by a flood depends primarily on topography and climate. Topographic factors include drainage area, slope, soil composition, and elevation. Climatic factors include precipitation intensity and precipitation distribution.
Floods are natural phenomena that can be catastrophic when people occupy the flood plain. Flood damage usually results from encroachment on a flood plain by industrial, commercial, and residential development. Areas where flooding may produce significant damage are known as flood-prone areas. A flood-prone area is defined as that area along a stream that would be inundated by a 100 -year flood as defined from a frequency curve of annual flood peaks at a gaged site. A 100-year flood has a 1 percent chance of occurring in any given year. 


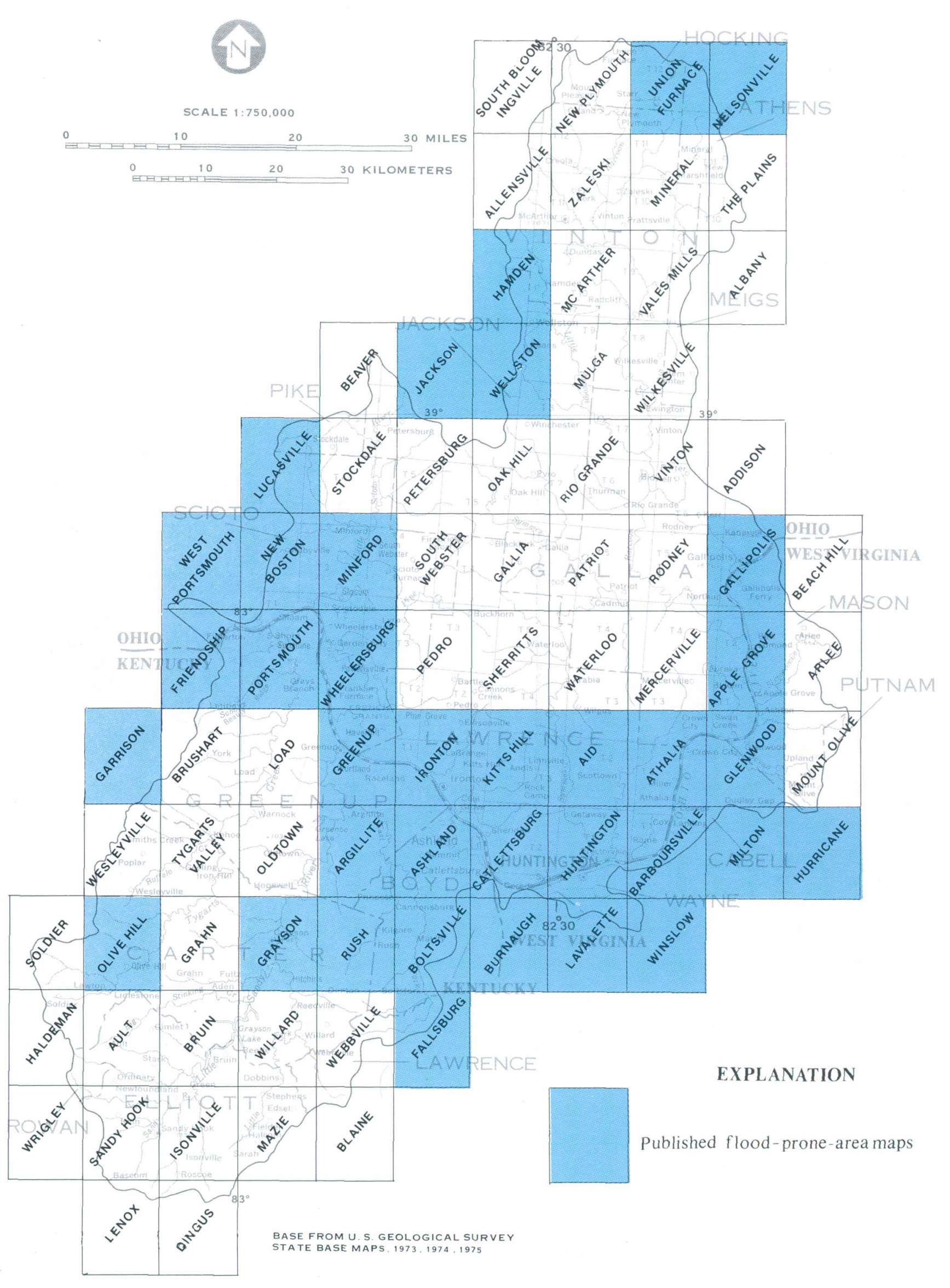

$82^{\circ} 05^{\prime} 30^{\prime \prime}$

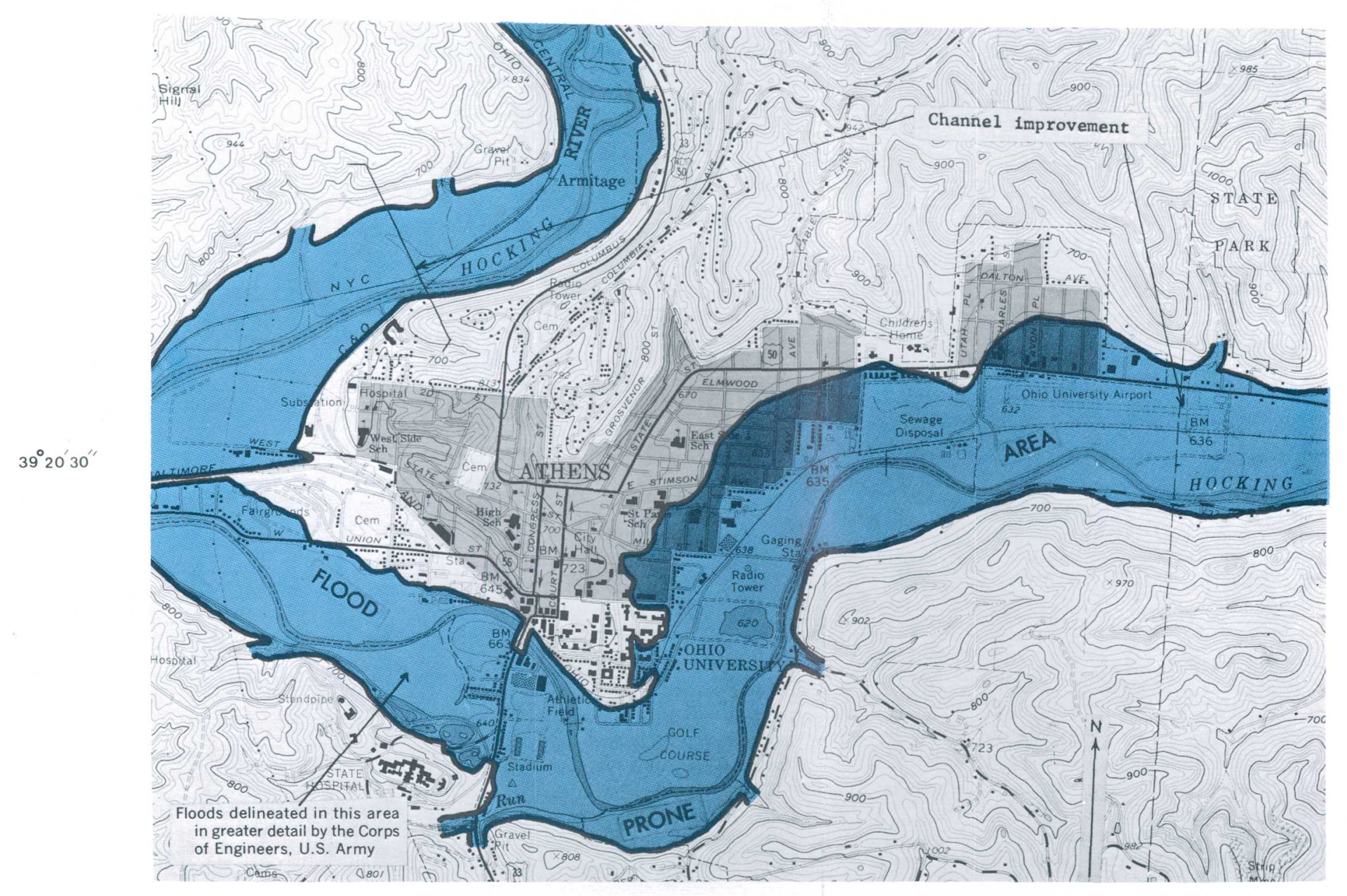

Base from U.S. Geological Survey

Figure 3.4-2 Part of flood- prone-area map of Athens, Ohio 


\title{
3.0 SURFACE-WATER QUANTITY--Continued 3.5 Magnitude and Frequency of Floods
}

\section{Small, Steeply Sloped Streams Generally have Higher Flood Magnitudes per Square Mile than Large, Low Gradient Streams in Area 11}

\author{
Equations are available for estimating flood frequency at ungaged sites.
}

The magnitude and frequency of floods vary according to (1) the size of the drainage area of the stream; (2) location of the stream in relation to the intensity and duration of precipitation; (3) the topography, which controls the rate of runoff and the area covered by a given volume of water; and (4) geology.

Flood-magnitude and frequency data for streams are used to design dams, bridges, and other structures. Flood data are also needed for flood-insurance studies, regulatory activities, and land zoning.

Flood-frequency curves ${ }^{1}$ are used to compute magnitude and frequency of floods for gaged streams. A typical flood-frequency curve for Area 11 (developed for Sandy Run near Lake Hope, site 47) is shown in figure 3.5-1. This curve shows the computed annual peak discharges (magnitude) for a range of recurrance intervals (frequency) and exceedance probabilities. The exceedance probability is the probability of a given flood or flow being equaled or exceeded in any year. The recurrence interval and exceedance probability are reciprocals. For example, the 100 -year flood peak has an exceedance probability of 0.01 , that is, a 1-percent chance of occurring in any year; the 2-year flood peak has as exceedance probability of 0.50 or a 50-percent chance of occurring in any year. At site 47 (fig. 3.5-1), the 50-year flood peak has a magnitude of 5,550 cubic feet per second, whereas the 2 -year flood peak has a magnitude of 691 cubic feet per second.

Small, steeply sloped streams generally have a greater runoff per square mile than the large streams in Area 11. The 2-year flood discharge for five unregulated sites in Area 11 (section 7.2) ranged from 10.8 cubic feet per second per square mile to 138 cubic feet per second per square mile (drainage areas are 585 square miles and 5.0 square miles, respectively).

The magnitude and the frequency of floods on ungaged streams may be estimated by regionalized regression equations. The geographic areas or regions within Area 11 for which regression equations have been developed are shown in figure 3.5-2. Equations for the 2-, 10-, 50-, and 100-year floods for each of these geographic areas are shown in table 3.5-1. The regression equations are not applicable to sites where manmade changes such as reservoirs, hydroelectric plants, irrigation, and urban development may alter floodflows in the drainage basin upstream from the site.
Basin characteristics for the regression equations shown in table 3.5-1 are determined as follows:

Drainage Area (A): In square miles; determined from a topographic map.

Slope (SL): Stream or main-channel slope, in feet per mile; the difference between the elevations at 10 percent $(0.1)$ and 85 percent $(0.85)$ of the channel length or distance from the site to the basin divide, divided by the channel distance between the two points as determined from a topographic map.

Average basin elevation index (E): In thousands of feet above sea level; computed by averaging the elevations at the 10 percent and 85 percent distance points along the channel as determined from a topographic map.

Average or mean annual precipitation $(P)$ : In inches; determined from an isohyetal map, minus 27 inches.

Geographic factor (R): A dimensionless geographical factor that provides an index of the variations in flood peaks with geology and topography.

Regression equations and methods for computing flood magnitude and frequency of ungaged streams are explained in detail in the following reports, which are listed in section 8.0: for Ohio, Webber and Bartlett (1977); for Kentucky, Hannum (1976); and for West Virginia, Runner (1980). Additional flood information can be obtained from the U.S. Geological Survey or the following State agencies:

\author{
Ohio Department of Natural Resources \\ Division of Water \\ Fountain Square \\ Columbus, $\mathrm{OH} 43224$ \\ Kentucky Geological Survey \\ 311 Breckinridge Hall \\ University of Kentucky \\ Lexington, KY 40506
}
West Virginia Geological and Economic Survey P.O. Box 879
Morgantown, WV 26505

\footnotetext{
${ }^{1}$ A flood-frequency curve is a graph showing the number of times per year, on the average, that floods of a given magnitude are equaled or exceeded (Langbein and Iseri, 1960).
} 
XCEEDENCE PROBABILITY

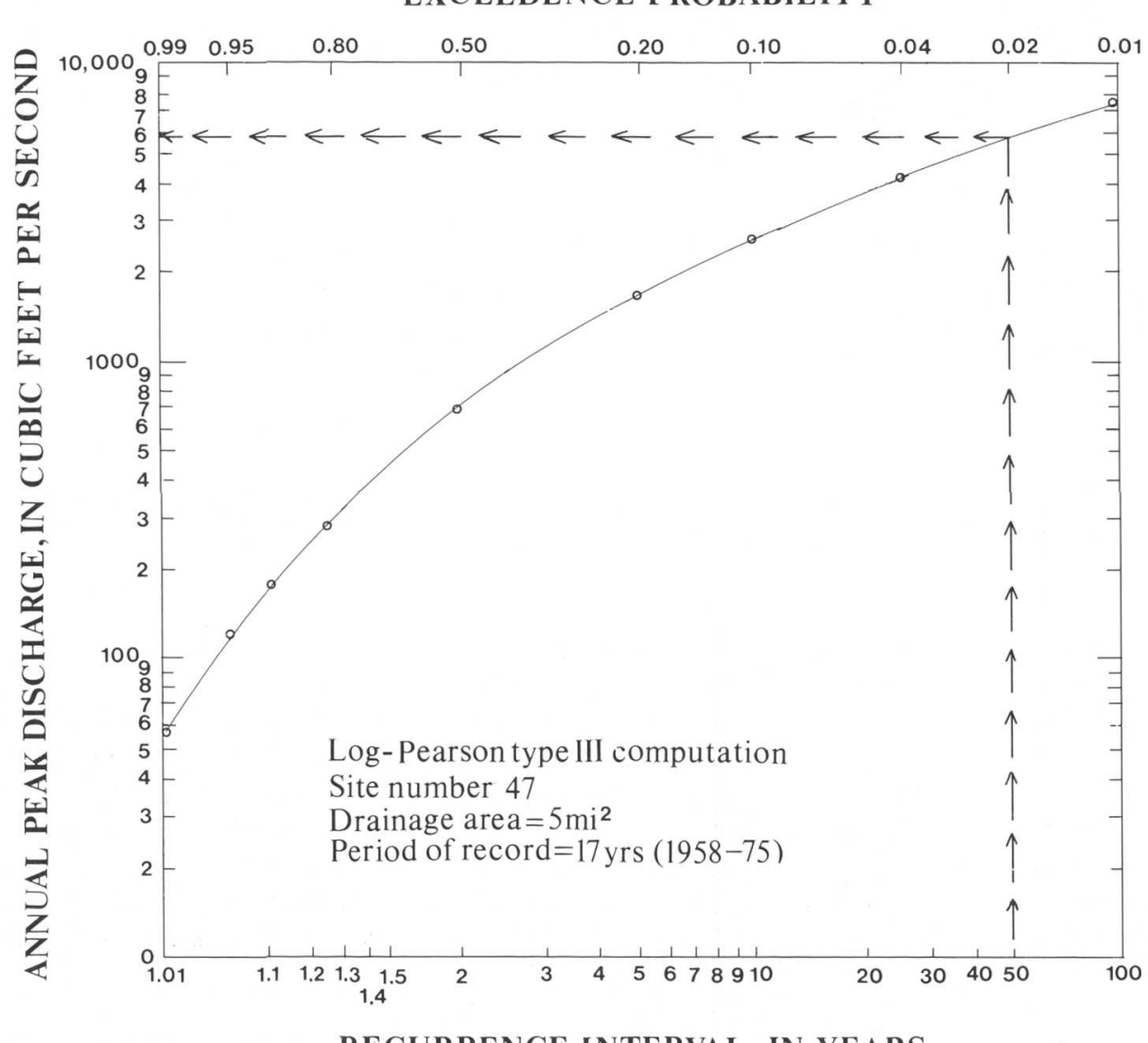

RECURRENCE INTERVAL, IN YEARS

Figure 3.5-1 Flood frequency curve for Sandy Run near Lake Hope,Ohio

\begin{tabular}{|c|c|c|c|c|c|c|}
\hline I & & Equation & SEE & I & & SEE \\
\hline & & Regien 3 - obie & & \multicolumn{2}{|r|}{ Region 2 - West Virginia } & \\
\hline 2 & $Q_{2}$ & $=7.27 \mathrm{~A}^{0.771} \mathrm{SL}^{0.24 \mathrm{E}^{-1.54} \mathrm{p}^{0} .802}$ & 27 & 2 & $Q_{2}=85 \mathrm{~A}^{0.830}$ & 43 \\
\hline 10 & $\mathrm{Q}_{10}$ & $=17.5 \mathrm{~A} 0.743 \mathrm{SL}^{0} 0.267 \mathrm{E}^{-1.39} \mathrm{P}^{0} .769$ & 27 & 10 & $Q_{10}=201 \mathrm{~A} 0.771$ & 38 \\
\hline 50 & $Q_{50}$ & $=29.1 \mathrm{~A} 0.732 \mathrm{SL}^{0.284} \mathrm{E}^{-1.32 \mathrm{p}^{0} .732}$ & 32 & 50 & $Q_{50}=354 \mathrm{~A}^{0.733}$ & 41 \\
\hline 100 & $\mathrm{Q}_{100}$ & $=34.7 \mathrm{~A} 0.729 \mathrm{SL}^{0.290} \mathrm{E}^{-1.30} 0.718$ & 34 & 100 & $Q_{100}=437 \mathrm{~A}^{0.719}$ & 44 \\
\hline & & Region 2-Ohie & & & Region 1 and 2 - Rent & \\
\hline 2 & $Q_{2}$ & $=42.6 \mathrm{~A}^{0.802} \mathrm{SL}^{0} 0.225$ & 33 & 2 & $Q_{2}=187 \mathrm{~A}^{0.70 \mathrm{R}_{\mathrm{R}} 0.965}$ & 31.8 \\
\hline 10 & $Q_{10}$ & $=47.4 \mathrm{~B}^{0.830} \mathrm{SL}^{0} .447$ & 27 & 10 & $Q_{10}=412 \mathrm{~A}^{0.677 \mathrm{R}^{1} .006}$ & 29.5 \\
\hline 50 & $Q_{50}$ & $=50.9 \mathrm{~A}^{0} .850_{\mathrm{SL}} 0.575$ & 29 & 50 & $Q_{50}=638 \mathrm{~A}^{0.66 \mathrm{R}_{\mathrm{R}} 1.040}$ & 31.8 \\
\hline 100 & $\mathrm{Q}_{100}$ & $=52.6 \mathrm{~A}^{0} .857 \mathrm{SL}^{0} 0.619$ & 32 & 100 & $Q_{100}=740 \mathrm{~A}^{0.65 \mathrm{R}_{\mathrm{R}} 1.051}$ & 33.3 \\
\hline
\end{tabular}

Explanation:

$Q=$ discharge, in cubic feet per second, for flood of indicated recurrence interval.

$\mathrm{A}=$ contributing drainage area, in square miles.

SL = Main-channel slope, in feet per mile.

E = Average basin elevation index, in thousands of feet above sea leve1.

$\mathrm{P}=$ Average precipitation, in inches, minus 27.0.

$R=$ Geographic factor: for Rentucky region $1, R=0.782$; for Kentucky region $2, R=1.773$.

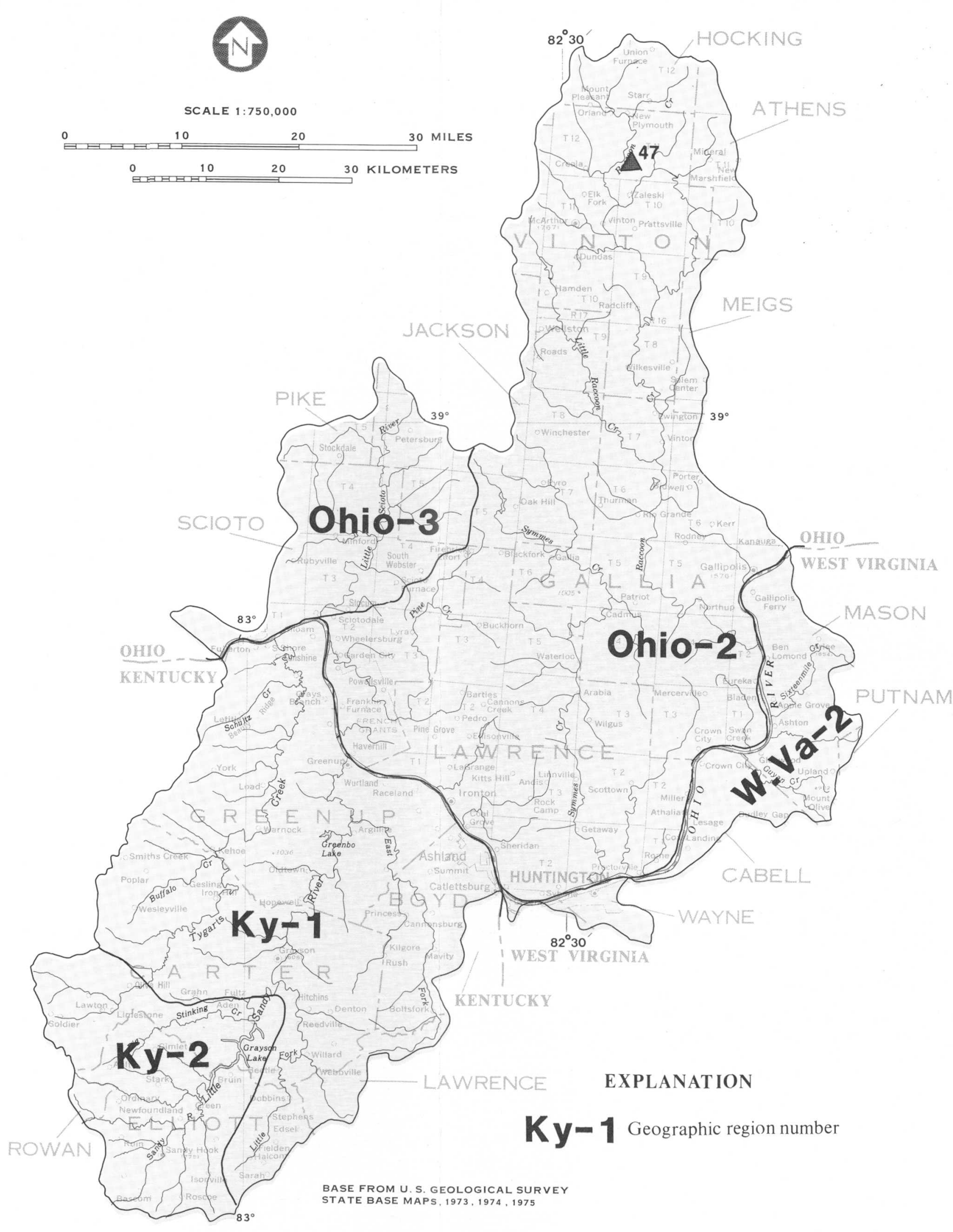

Figure 3.5-2 Geographic regions of regionalized regression equations (Webber and Bartlett, 1977; Hannum, 1976; and Runner, 1980) 


\title{
3.0 SURFACE-WATER QUANTITY--Continued 3.6 Flow Duration
}

\section{Many of the Small Streams Reach Zero or Near-Zero Flow During Periods of Drought}

\author{
Most streams have relatively rapid runoff with little contribution from \\ ground water.
}

Flow-duration data are available for five unregulated and three regulated continuous-record stations. Locations of the stations are shown in figure 3.6-1.

The flow-duration curve ${ }^{1}$ represents the entire range of flow that occurred during the period of record. The data have little meaning when streamflow is affected by regulation, unless the data are for a nonregulated period or have been adjusted.

Typical flow-duration curves for Area 11 are shown in figures 3.6-2 (Raccoon Creek at Adamsville, Ohio, site 52) and 3.6-3 (Sandy Run near Lake Hope, Ohio, site 47). The steepness of the duration curves of these streams is typical of the Ohio River tributaries in the Appalachian Plateau, which is characterized by moderately rugged topography. The upper and middle parts of the two duration curves indicate that the streams have rapid runoff. The steepness of the lower parts of these duration curves indicates that the geologic formations do not store or release much water. The extreme steepness of the lower part of the Sandy Run duration curve indicates that in many years, daily flows reach zero during dry periods. The slightly flatter lower end of the Raccoon Creek duration curve indicates that in many years, daily flows are low but do not normally reach zero. Four of the eight unregulated sites have 7-day, 10-year low flows equal to zero (see section 7.2).

Flow-duration discharges per square mile have been determined for eight of the 10 continuous-record sites in Area 11 (section 7.2). The 50-percent duration discharge (the average daily flow that is exceeded 50 percent of the time) ranges from 0.30 to 0.47 cubic feet per second per square mile. The average 50 percent duration discharge for the five unregulated sites is 0.37 cubic feet per second per square mile.

\footnotetext{
${ }^{1}$ The flow-duration curve is a cumulative frequency curve that shows the percentage of time specified discharges are equaled or exceeded during a given period of record.
} 


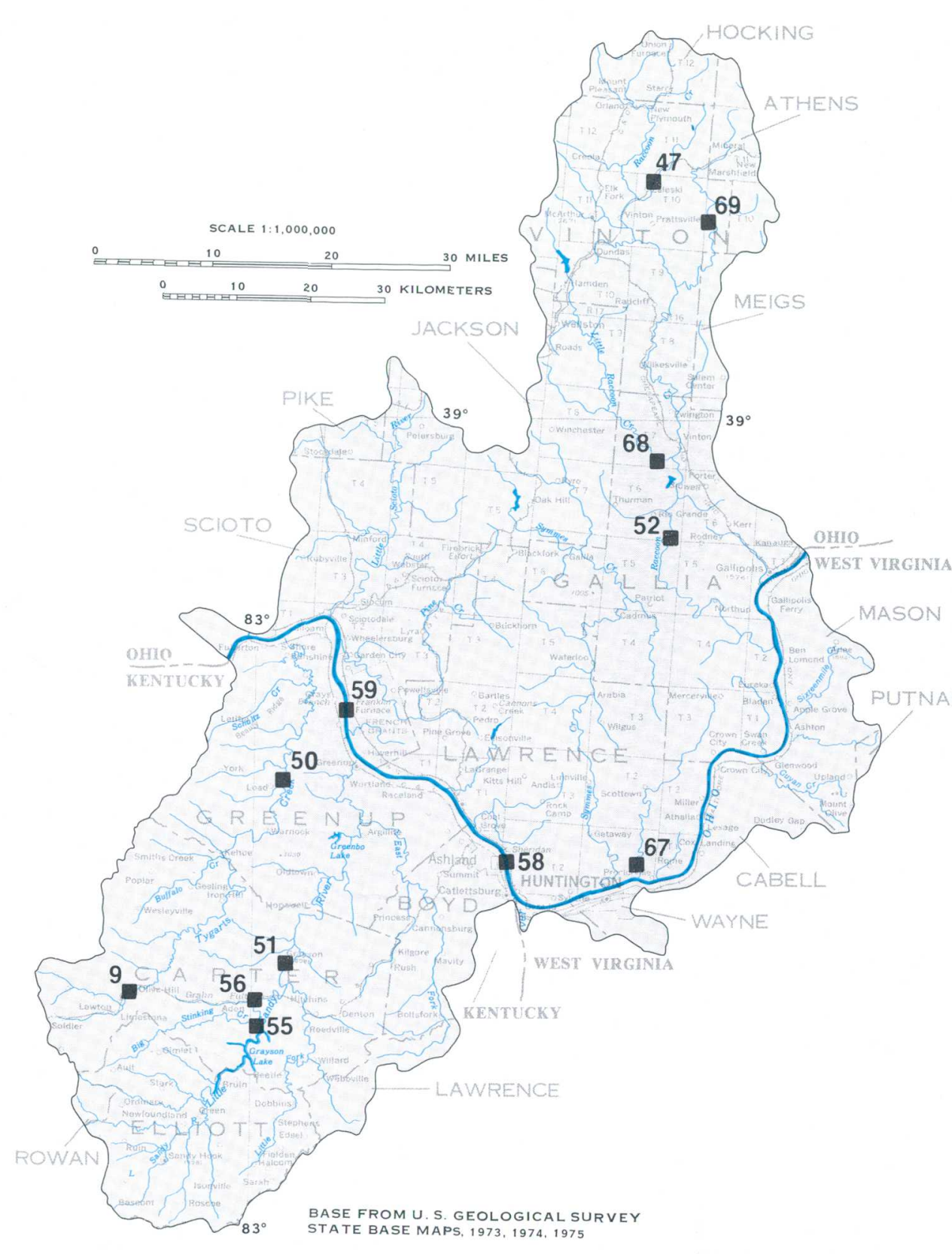

Figure $3.6-1$ Sites in Areall for which flow-duration are available

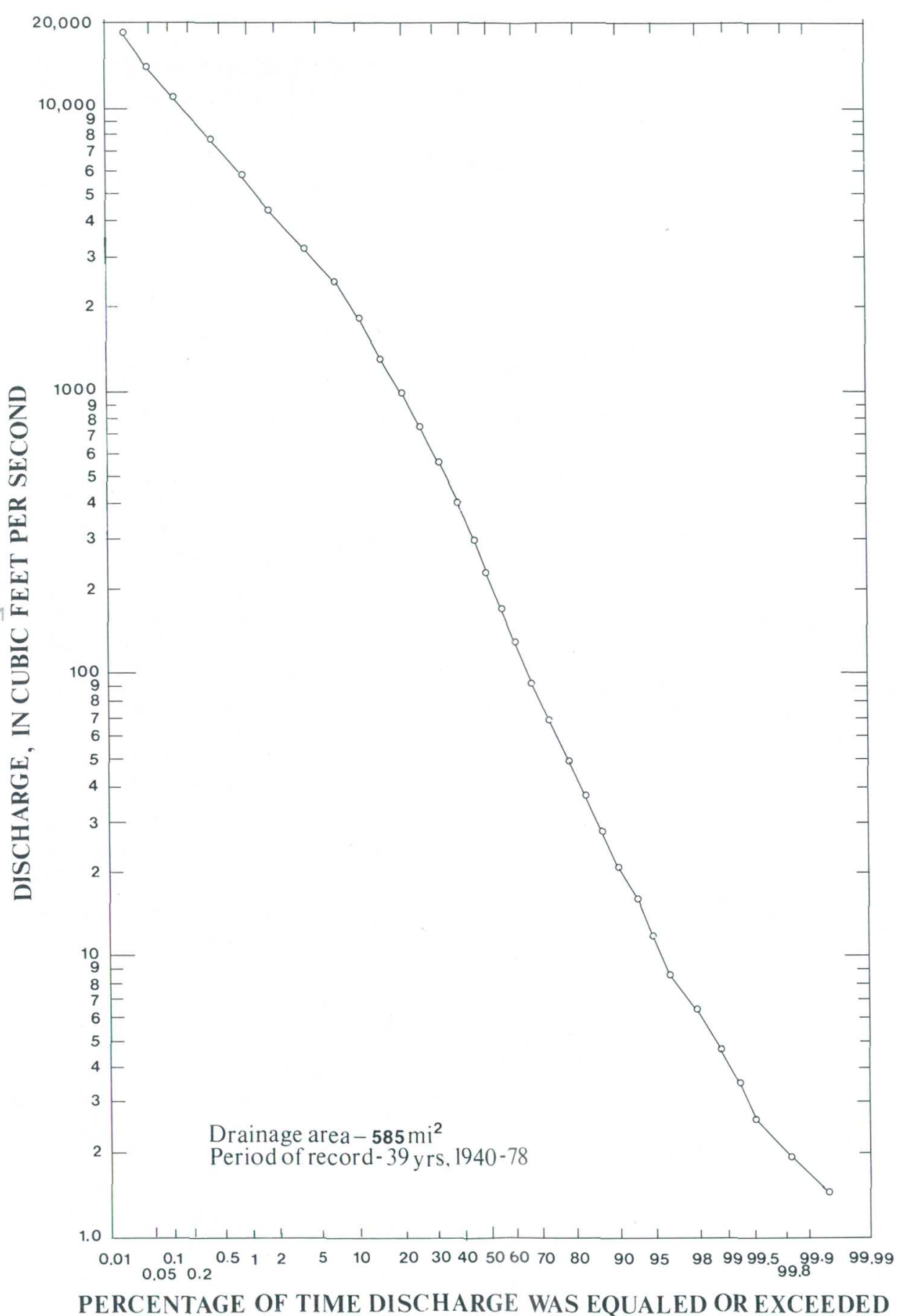

PERCENTAGE OF TIME DISCHARGE WAS EQUALED OR EXCEEDED

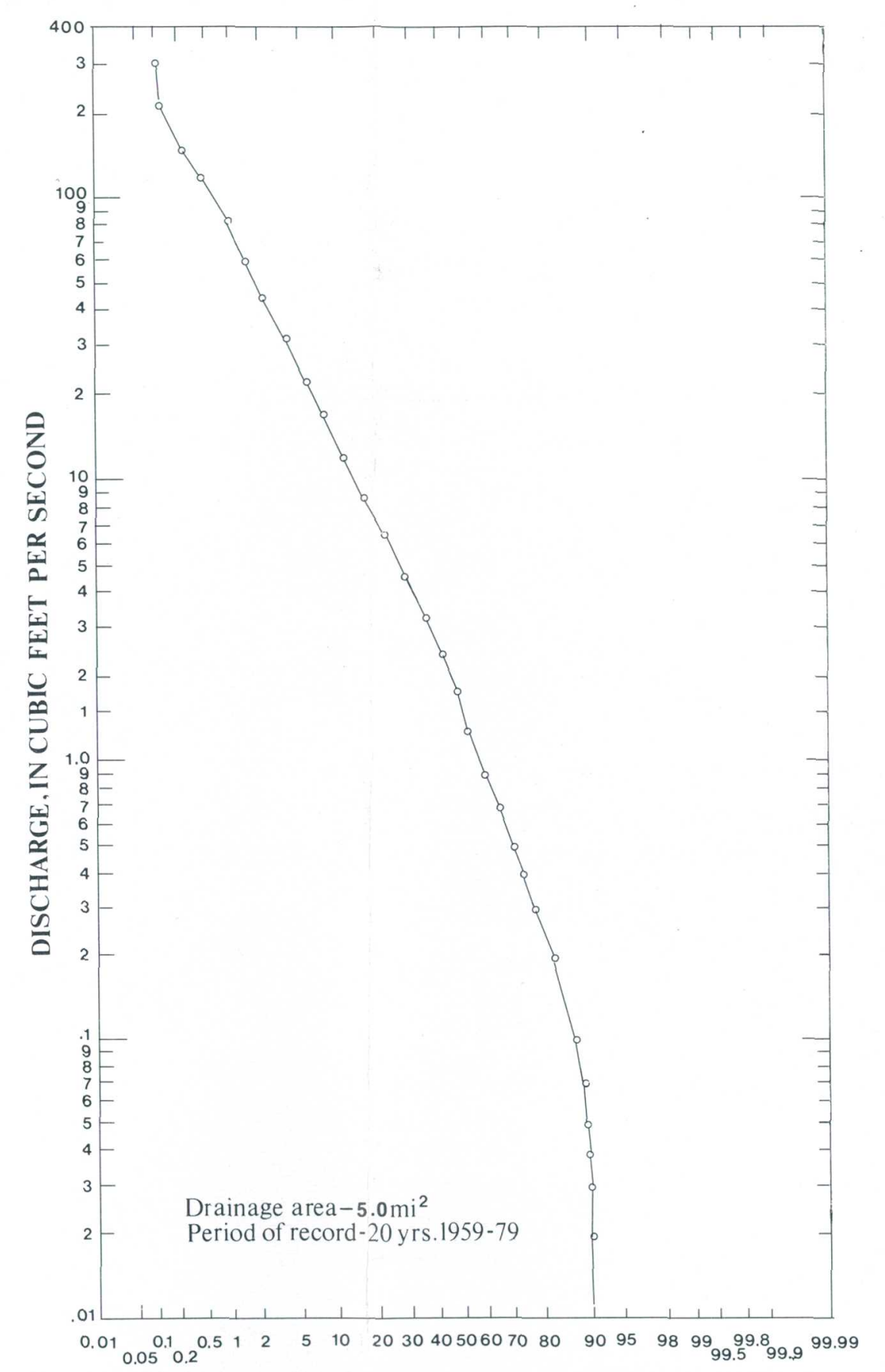

PERCENTAGE OF TIME DISCHARGE WAS EQUALED OR EXCEEDED

Figure 3.6-2 Flow-duration curve of Racoon Creek at Adamsville, Ohio ( site 52 


\title{
4.0 SURFACE-WATER QUALITY \\ 4.1 Specific Conductance
}

\section{In Area 11, Specific Conductance is Highest in Streams Draining Mined Areas}

\author{
Specific conductance of surface waters ranged from 95 to 3,000 micromhos per \\ centimeter; the highest conductances were found immediately downstream \\ from areas affected by mining.
}

Concentrations of dissolved substances (dissolved solids) in streams can differ widely as a result of natural conditions and human activity. Specific conductance ${ }^{1}$ of solutions increases as the concentration of dissolved solids increases. Generally, the dissolved-solids concentration of a stream is lowered by dilution; thus, specific conductance is usually highest during low flow.

The high specific conductance in coal-mined areas (fig. 4.1-1) is due to the chemical reactions of air and water with the mineral pyrite, which is present in coal and associated rocks. These reactions generally take place in partly flooded underground mines and exposed spoil piles in surface mines. The acidic drainage that results reacts further with other minerals as it enters a stream and produces high dissolved-solids concentrations. Generally, the high dissolved-solids concentrations decrease with distance downstream of mined areas because of dilution by tributary streams.

The range of specific conductance for unmined ${ }^{2}$ sites was from 95 micromhos per centimeter at $25^{\circ} \mathrm{C}$ $(\mu \mathrm{mho} / \mathrm{cm})$ at site 39 to $775 \mu \mathrm{mho} / \mathrm{cm}$ at site 7 . The minimum specific conductance for mined ${ }^{2}$ sites ranged from $95 \mu \mathrm{mho} / \mathrm{cm}$ at site 61 (downstream of a reclamation project) to $3,000 \mu \mathrm{mho} / \mathrm{cm}$ at site 62 . The median specific conductance for all unmined sites was $277 \mu \mathrm{mho} / \mathrm{cm}$, whereas the median for all mined sites was $573 \mu \mathrm{mho} / \mathrm{cm}$. Ranges of median specific conductance at mined and unmined sites are shown in figure 4.1-1.

\footnotetext{
${ }^{1}$ Specific conductance is the ability of water to conduct an electrical current, and is a good indicator of total dissolved-solids concentration.

${ }^{2}$ For the purposes of this report, an "unmined" site is a site whose drainage area is less than 10 percent mined, whereas a "mined" site is a site whose drainage area is at least 10 percent mined.
} 


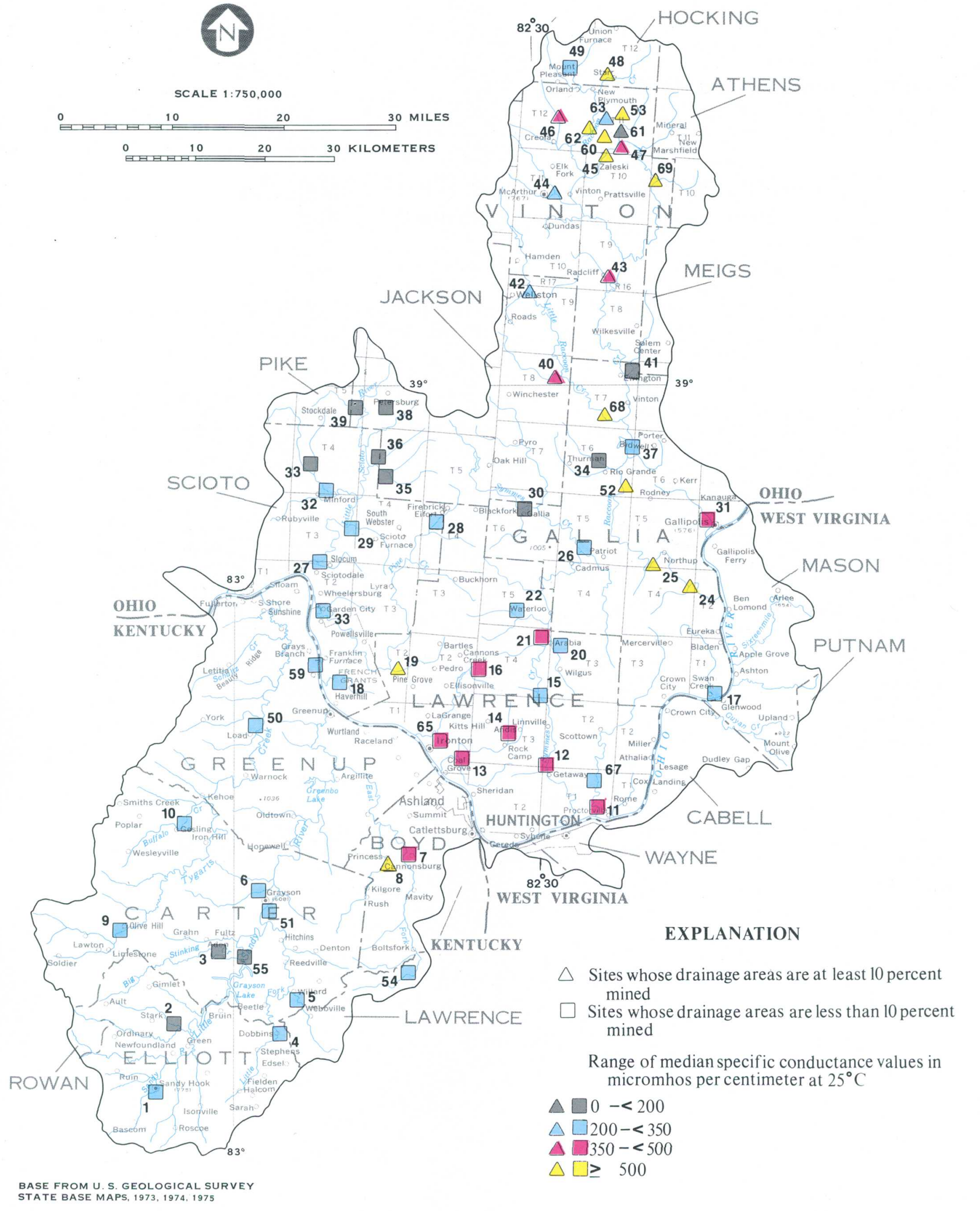

Figure 4.1-1 Median values of specific conductance at selected sites in Area 11 


\subsection{SURFACE-WATER QUALITY--Continued \\ $4.2 \mathrm{pH}$}

\section{Lowest pH Values are in Areas Where Mining was Present and Limestone was not Abundant}

\section{Sites downstream from mining areas exhibit a wider range in $\mathrm{pH}(2.6$ to 8.2) than sites in unmined areas (6.1 to 8.8).}

Water with a $\mathrm{pH}^{1}$ less than 7.0 is described as acidic, and water with a $\mathrm{pH}$ more than 7.0 is described as alkaline. Vinegar has a $\mathrm{pH}$ of about 2.5 and household ammonia has a pH of about 12 .

Natural acidity in streams is usually caused by the weathering of rocks and organic matter in soils (Hem, 1970). A stream unaffected by mining or pollution in a basin underlain by limestone, sandstone and shale generally will have a pH of 6.5 to 8.5.

The mineral pyrite is the primary source of hydrogen ions (acidity) in mined basins. Carbonate minerals found in limestone are a source of alkalinity; the ions associated with the carbonate minerals tend to neutralize the acid produced from pyrite oxidation.
The $\mathrm{pH}$ of a stream draining a mined area is highly dependent on the amount of carbonate minerals present in the bedrock. Because the carbonate content of bedrock differs considerably throughout Area 11, there is a correspondingly wide range of $\mathrm{pH}$ (2.6 to 8.2 ) among the mined sites.

The minimum $\mathrm{pH}$ measured for mined basins in Area 11 was 2.6 at sites 53 and 62 . The maximum $\mathrm{pH}$ measured for mined basins was 8.2 at site 63 . The median $\mathrm{pH}$ for all mined sites in Area 11 was 5.4. The maximum $\mathrm{pH}$ measured for the unmined basins was 8.8 at site 14 and the minimum measured $\mathrm{pH}$ was 6.1 at site 59 . The median $\mathrm{pH}$ for all unmined basins was 7.3. The ranges of median values for $\mathrm{pH}$ are shown in figure 4.2-1.

\footnotetext{
${ }^{1}$ The activity of hydrogen ions in reaction with dissolved substances is indicated by the $\mathrm{pH}$ of a solution. Mathematically, $\mathrm{pH}=-\log \left[\mathrm{H}^{+}\right]$ where $\left[\mathrm{H}^{+}\right]$is the hydrogen-ion activity. The mathematical expression indicates that as the hydrogen-ion activity increases, the $\mathrm{pH}$ decreases.
} 


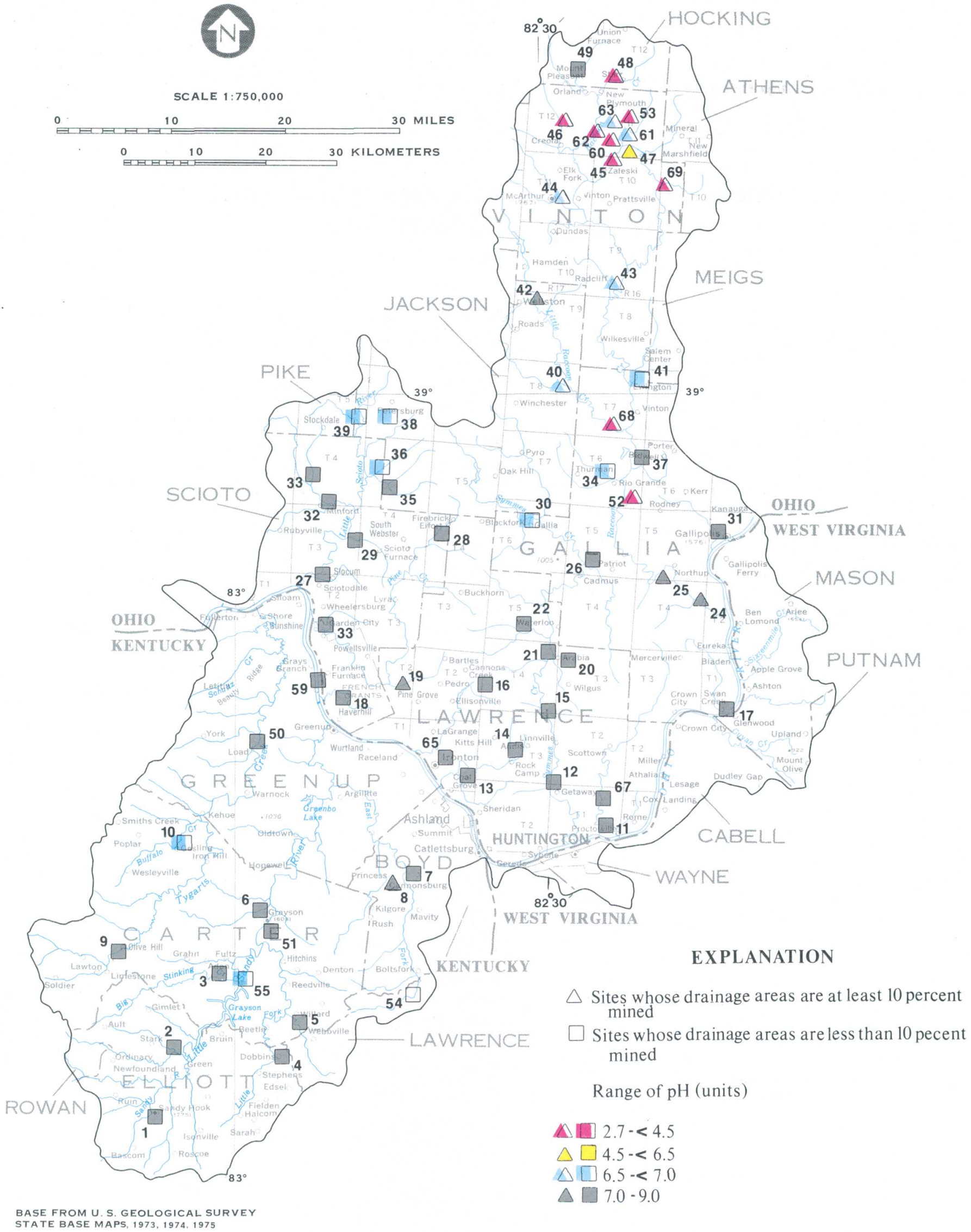

Figure 4.2-1 Median values of $\mathrm{pH}$ at selected sites in Area 11 


\title{
Iron Concentrations Generally Higher in Mined Areas than in Unmined Areas
}

\author{
Dissolved iron ranged from 0 to 430 micrograms per liter at unmined sites and \\ from 0 to 150,000 micrograms per liter at mined sites.
}

Iron, the fourth most abundant element by weight in the earth's crust, is an essential element for plant and animal life. The most common forms of iron are the ferrous ion $\left(\mathrm{Fe}+{ }^{2}\right)$ and the ferric ion $\left(\mathrm{Fe}+{ }^{3}\right)$. The ferrous ion is common in water containing little or no dissolved oxygen, such as ground water. The ferric ion hydrolizes readily to ferric hydroxide, which is insoluble in water. The behavior of iron in natural water is related to $\mathrm{pH}$ and $\mathrm{Eh}$ (Hem, 1970). Eh is the oxidizing or reducing potential of a system expressed in volts.

The ferrous form of iron found in sediments is present in the minerals pyrite and marcasite. Pyrite, the more common of the two minerals in coalbearing strata of Area 11, is the primary contributor of iron to the aquatic system. On exposure to atmospheric oxygen, dissolved ferrous ions are released and oxidized to ferric ions. The ferric ions in solution are then hydrolyzed to produce insoluble ferric hydroxide, $\mathrm{Fe}(\mathrm{OH})_{3}$ (Harvard University, 1970).

Iron hydroxide $\left(\mathrm{Fe}(\mathrm{OH})_{3}\right)$ and the iron oxide $\left(\mathrm{Fe}_{2} \mathrm{O}_{3}\right)$ produce yellow and red precipitates, respectively, and form loosely aggregated, fine suspended matter called floc. Floc covers bottom gravels in stream beds and may destroy bottom-dwelling organisms and the suitability of spawning grounds for fish (U.S. Environmental Protection Agency, 1976).

Sites having high concentrations of dissolved iron are associated with low $\mathrm{pH}$ values. The solubility of iron is greater in waters having low $\mathrm{pH}$ than in waters having high $\mathrm{pH}$. One exception is site 8 , a mined site, where the median dissolved-iron concentration was 1,900 micrograms per liter $(\mu \mathrm{g} / \mathrm{L})$ and the median $\mathrm{pH}$ was 7 .

The median dissolved-iron concentration was 90 $\mu \mathrm{g} / \mathrm{L}$ for all unmined sites. At mined sites, the median concentration was $893 \mu \mathrm{g} / \mathrm{L}$, about 10 times higher than at unmined sites. The concentrations ranged from $0 \mu \mathrm{g} / \mathrm{L}$ at site 10 to $430 \mu \mathrm{g} / \mathrm{L}$ at site 30 in unmined areas, whereas concentrations ranged from $0 \mu \mathrm{g} / \mathrm{L}$ at site 61 (a mined site that has been extensively reclaimed) to $150,000 \mu \mathrm{g} / \mathrm{L}$ at site 62 in mined areas. The ranges of median dissolved-iron concentrations are shown in fig. 4.3-1.

Most of the high dissolved-iron concentrations were at sites close to mined areas where the mineral pyrite has been exposed to oxygen and water. As the water travels downstream from the pyrite source, the concentrations of dissolved iron usually decrease significantly. Relatively small shifts in Eh or $\mathrm{pH}$, along with the availability of oxygen, can cause dramatic changes in the solubility of iron.

The Raccoon Creek basin in Area 11 provides an example of the changes in the solubility of iron that can occur. Dissolved-iron concentrations over $100,000 \mu \mathrm{g} / \mathrm{L}$ were measured in headwater tributaries (near mining sources) but had decreased to $130 \mu \mathrm{g} / \mathrm{L}$ at site 52 (about 15 miles downstream from mining sources). 


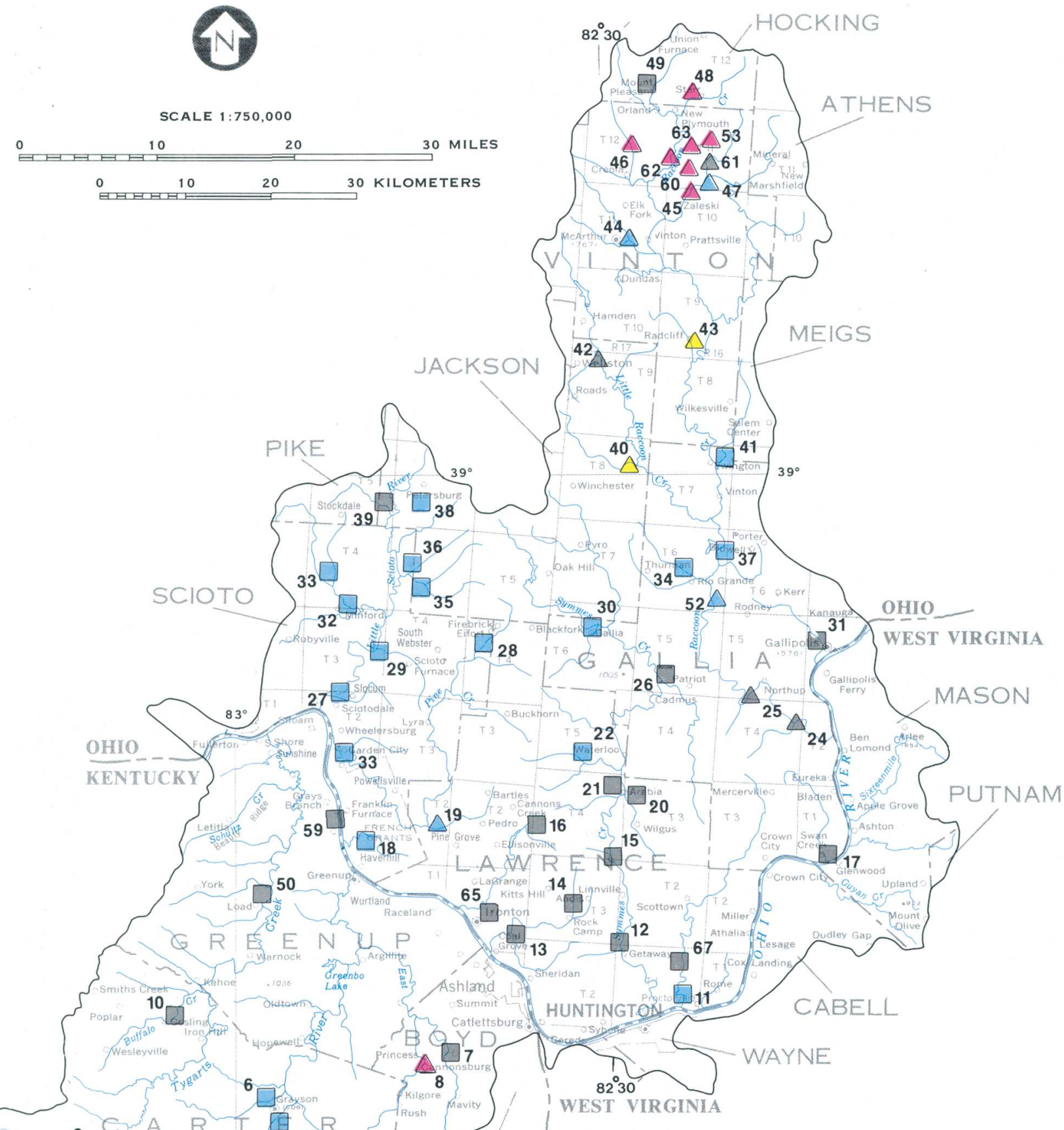

EXPLANATION

$\triangle$ Sites whose drainage areas are at least 10 percent mined

Sites whose drainage areas are less than 10 percent mined

Range of median dissolved iron values in micrograms per liter
$\triangle \square \quad 0-<100$
$\triangle \square 100-<500$
$\triangle \square 500-<1000$
$\Delta \square \geq 1000$

BASE FROM U.S. GEOLOGICAL SURVEY STATE BASE MAPS, 1973, 1974, 1975

Figure 4.3-1 Median iron concentrations at selected sites in Area 11 


\subsection{SURFACE-WATER QUALITY--Continued \\ 4.4 Manganese}

\section{Manganese Concentrations Highest in Streams Draining Mined Areas}

\section{Median values of dissolved manganese concentrations were 10 to 15 times greater at sites draining mined areas then at sites not affected by mining.}

Manganese is a common element in rocks, soils, and natural waters. Manganese, like iron, is an essential element for the metabolism of plant life (Hem, 1970): Concentrations of manganese in excess of 150 micrograms per liter $(\mu \mathrm{g} / \mathrm{L})$ produce an objectionable taste in water and can cause staining of fabrics (U.S. Environmental Protection Agency, 1976).

In mined areas, high concentrations of manganese in the streams can result from accelerated weathering of manganese-rich minerals exposed in the mine spoils. In addition, the oxidation of pyrite produces a reducing environment that, in combina- tion with low $\mathrm{pH}$, increases the concentration of soluble manganese in streams (Hem, 1976).

The ranges of median concentrations of dissolved manganese at sites in mined and unmined areas are shown in figure 4.4-1. Concentrations in mined areas ranged from a minimum of $10 \mu \mathrm{g} / \mathrm{L}$ at sites 60 and 61 to a maximum of $52,000 \mu \mathrm{g} / \mathrm{L}$ at site 62. In unmined areas, the range was much smaller (from $2 \mu \mathrm{g} / \mathrm{L}$ at site 59 to $1,200 \mu \mathrm{g} / \mathrm{L}$ at site 4 ). The median dissolved-manganese concentration for all the unmined sites was $162 \mu \mathrm{g} / \mathrm{L}$, whereas the median for all the mined sites was $2,300 \mu \mathrm{g} / \mathrm{L}$. Site 61 (a mined site which has been reclaimed) had a median dissolved-maganese concentration of $20 \mu \mathrm{g} / \mathrm{L}$. 

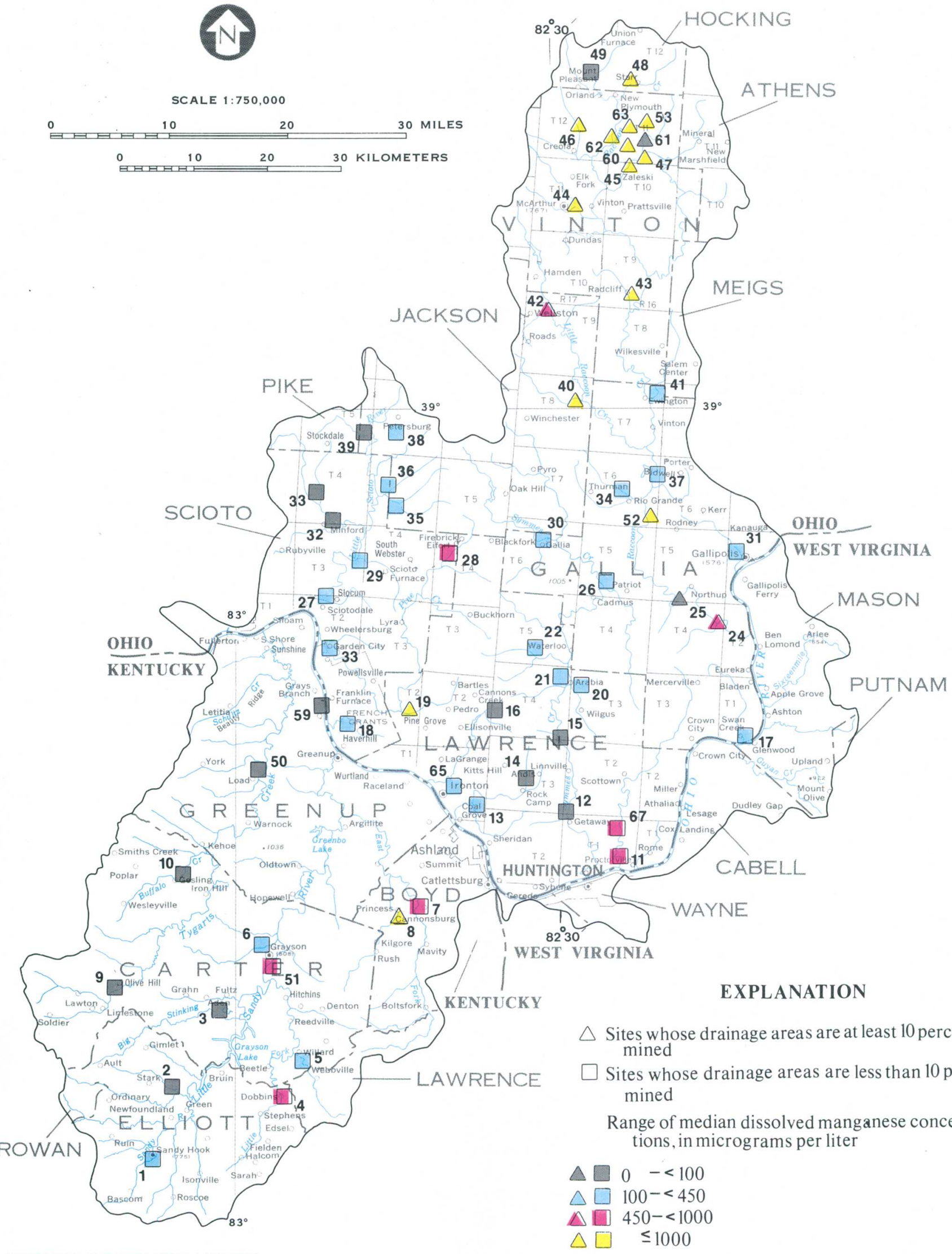

BASE FROM U.S. GEOLOGICAL SURVEY

EXPLANATION

STA TE BASE MAPS, 1973, 1974, 1975

Figure 4.4-1 Median dissolved maganese values at selected sites in Areall 


\title{
4.0 SURFACE-WATER QUALITY--Continued \\ 4.5 Sulfate
}

\section{Sulfate Concentrations were Highest in Streams Draining Mined Areas}

\begin{abstract}
The median concentration of sulfate in streams draining mined areas was approximately four times higher than that in streams draining unmined areas.
\end{abstract}

Sulfur is a major constituent in the earth's crust. In coal mining areas, sulfates are produced by oxidation and weathering of the mineral pyrite and are carried to streams by surface runoff and groundwater discharge. Generally, sulfate concentrations decrease downstream of mined areas because of dilution by tributary streams. Concentrations are usually highest during low flow.

Sulfate concentrations correlated significantly with specific conductance. The dissolved-sulfate concentrations were higher in mined areas than in unmined areas at corresponding levels of specific conductance. The ranges for specific conductance and dissolved sulfate were larger in mined areas than in unmined areas (fig. 4.5-1).

The sulfate concentrations at unmined sites ranged from a minimum of 9.8 milligrams per liter $(\mathrm{mg} / \mathrm{L})$ at site 55 to a maximum of $254 \mathrm{mg} / \mathrm{L}$ at site 7. At mined sites, the concentrations ranged from a minimum of $38 \mathrm{mg} / \mathrm{L}$ at site 61 (a mined site that has been extensively reclaimed) to a maximum of 2,100 $\mathrm{mg} / \mathrm{L}$ at site 62 . The median sulfate concentration for all unmined sites was $50 \mathrm{mg} / \mathrm{L}$, whereas the median sulfate concentation for all mined sites was $203 \mathrm{mg} / \mathrm{L}$. Median sulfate concentrations at all sites are shown in figure 4.5-2. 


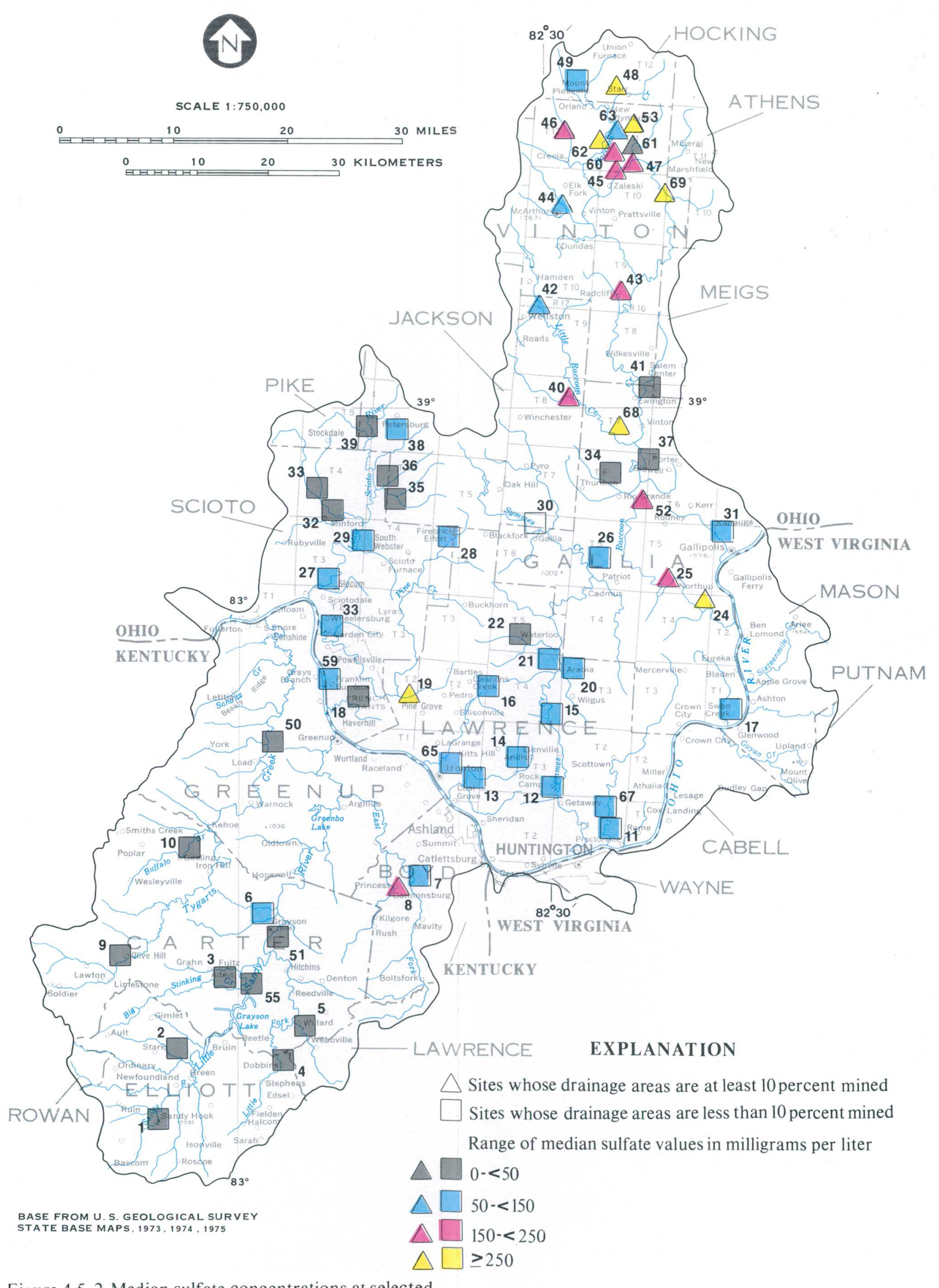




\subsection{SURFACE-WATER QUALITY--Continued 4.6 Trace Elements}

\section{Median Trace-Element Concentrations Differ Little Between Mined and Unmined Areas}

\section{Maximum concentrations of trace elements differed significantly between mined and unmined sites.}

Trace elements consist primarily of metals of low solubility that are present naturally in water. Most of these elements are essential to life in low concentrations, but some are toxic to plants and animals in high concentrations. Trace elements are found in a variety of rocks and soils; small amounts of trace elements make their way into natural waters under normal weathering conditions. Mine drainage and industrial-waste discharge are usually associated with high trace-metal concentrations.

Many coal and coal-bearing strata contain trace elements. Trace elements were sorbed by clay minerals and organic detritus during the early formation of coals and associated sediments. Circulating ground waters tend to increase trace-element concentrations in buried strata (Murchison and Westoll, 1968).

The trace elements investigated in Area 11 were arsenic, cadmium, chromium, copper, lead, mercury, selenium, and zinc. The results of chemical analyses of these elements are summarized in figure 4.6-1. Small amounts of chromium, copper, selenium, and zinc are essential and beneficial in animal metabolism and as plant nutrients. The remaining four elements (arsenic, cadmium, lead, and mercury) have no nutritional benefits and are generally consid- ered to be toxic (U.S. Environmental Protection Agency, 1976).

As shown in figure 4.6-1, the median concentations of trace elements in bottom material differed little between the mined and unmined areas. Maximum concentrations of cadmium and zinc were the same at both mined and unmined sites. Maximum concentrations of chromium, copper, and selenium were slightly higher at mined sites, whereas maximum concentrations of arsenic, lead, and mercury were considerably higher at unmined sites.

Concentrations of dissolved arsenic, zinc, and mercury were compared to the U.S. Environmental Protection Agency (USEPA) water-quality criteria for freshwater aquatic life (U.S. Environment Protection Agency, 1977). Neither arsenic nor zinc were present in excess of the USEPA limits of 50 and 5,000 micrograms per liter $(\mu \mathrm{g} / \mathrm{L})$, respectively. The U.S. Geological Survey laboratory detection limit for mercury $(0.1 \mu \mathrm{g} / \mathrm{L})$ is higher than the limit of 0.05 $\mu \mathrm{g} / \mathrm{L}$ established by USEPA. Dissolved mercury concentrations exceeded $0.1 \mu \mathrm{g} / \mathrm{L}$ at one mined site (19) and three unmined sites $(50,51$, and 59). The highest dissolved-mercury concentration was 1.0 $\mu \mathrm{g} / \mathrm{L}$ at site 59 on the Ohio River. 


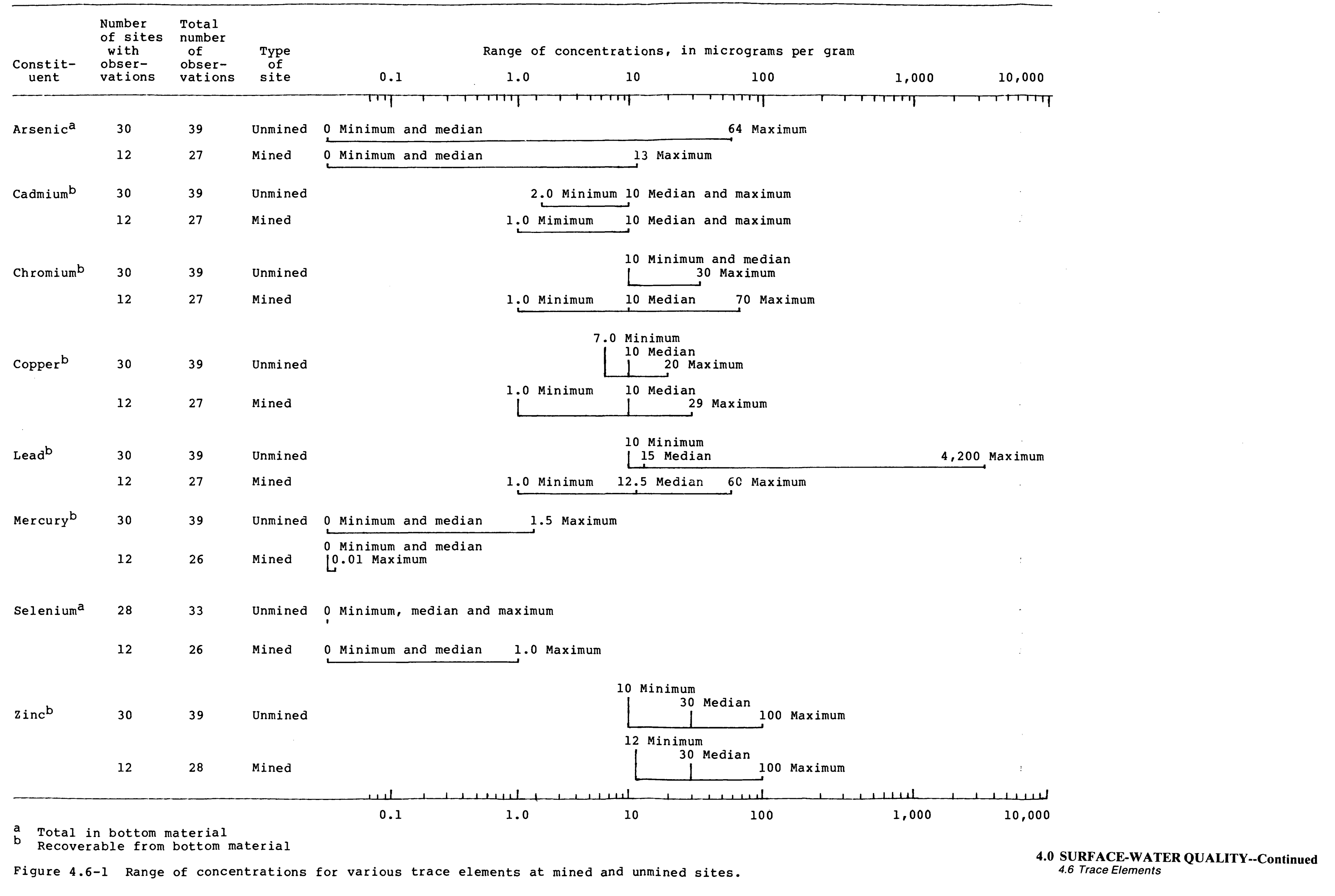




\subsection{SURFACE-WATER QUALITY--Continued 4.7 Sediment}

\section{Long-Term Sediment Data are Sparse}

\section{Sediment loads were observed to be higher in surface-mined areas of Area 11.}

Suspended solids are common in surface waters. These solids consist largely of sediments from eroded soil, but also include organic debris and microscopic plants and animals. Stream discharge varies seasonally--high flow usually occurring in the spring and low flow during late summer and autumn. Suspended-sediment loads are related to the streamdischarge pattern (fig. 4.7-1). Sediment loads of streams are greater in the spring than in summer because runoff and erosion are greater in the spring.

Data on streams in Area 11 are inadequate to correlate land use to sediment loads. However, the available data, together with field observations, suggest that sediment loads are higher in areas of surface mining. The high sediment loads from surface mined areas generally result from the erosion of the exposed, unconsolidated spoil piles during rainstorms. The increase in sediment load is usually of short duration if the area has been reclaimed, but erosion and sedimentation can be a local problem in unreclaimed areas.

The effects of eroded sediment on a stream channel and the flood plain at and downstream from a mined area are illustrated in figure 4.7-2. At both sites, the channel is completely filled with sediment and devoid of observable aquatic life and vegetation. At the mine site (fig. 4.7-2A), a yellow-red precipitate covers the channel bottom; dead trees and aquatic vegetation can be seen along the flood plain. An eroding spoil pile is at the right side of the picture.

Wastes from industries and communities, extensive agriculture, and mining are important factors contributing to suspended sediment in surface water. High concentrations of suspended solids may clog the gills and the respiratory passages of aquatic life and cause abrasive injuries. Sediment covering streambeds may destroy spawning areas for aquatic life (McKee and Wolfe, 1976). 

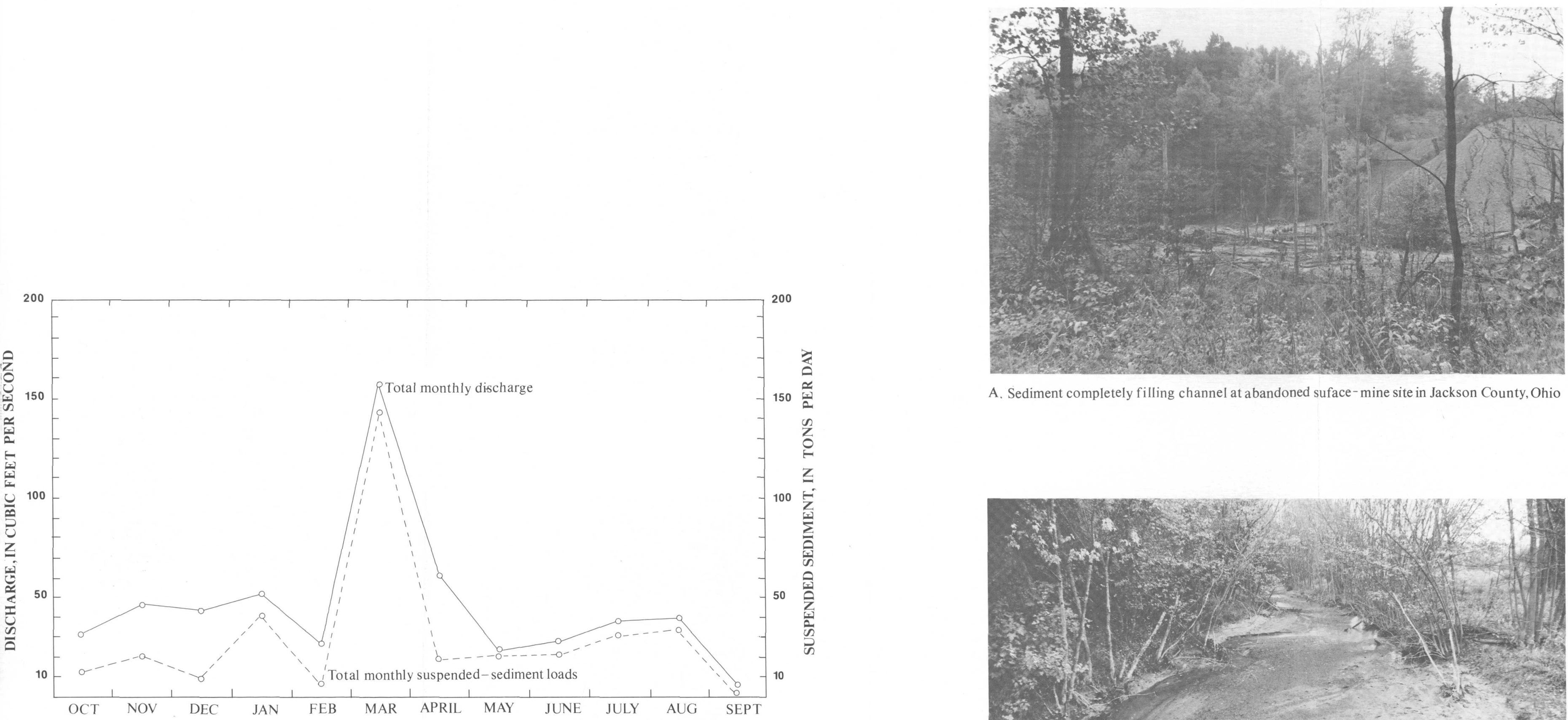

A. Sediment completely filling channel at abandoned suface-mine site in Jackson County Ohio

Figure 4.7-1 Relation between discharge and suspended -sediment loads at site 52 in Areall for one yea 


\title{
5.0 GROUND WATER \\ 5.1 Y yield
}

\section{Water-Well Yields Range Widely in Area 11}

\author{
Bedrock aquifers generally yield less than 5 gallons per minute, whereas sand \\ and gravel aquifers along the Ohio River yield more than 500 gallons per minute.
}

Most of the Ohio and West Virginia parts of Area 11 are underlain by sandstone, siltstone, shale, coal, and limestone of the Pennsylvanian System (Bernhagen, 1947; Krebs and Teets, 1913). Sandstone aquifers are the most important sources of ground water in these strata. Typically, water is stored in the pore spaces between sand grains, in rock fractures, and along bedding planes. In general, these sandstone bedrock aquifers yield less than 5 gallons per minute (fig. 5.1-1). In a few areas where aquifers are highly fractured and are recharged locally by infiltration from surface waters, bedrock wells are known to yield 10 to 20 gallons per minute (Sedam and Stein, 1970).

The Conemaugh and Monongahela Formations of the Pennsylvanian System are relatively unimportant as sources of water. The major water producers in the Allegheny Formation are the Clarion, Lower Freeport, and Upper Freeport Sandstones. The basal Sharon Conglomerate Member of the Pottsville Formation is the most significant source of ground water in the Pennsylvanian System in Ohio (Bernhagen, 1947).

In most of the Kentucky part of Area 11, ground water is obtained from the Breathitt and Lee Formations of the Pennsylvanian System. In the Tygart's Creek basin, however, some bedrock wells are in limestone of Mississippian age. Bedrock wells in the Kentucky part of Area 11 generally yield less than 5 gallons per minute (Price and others, 1962).

Wells in sand and gravel deposits along major streams generally are somewhat more productive than the bedrock wells. In Ohio, yields of wells in such watercourse aquifers range from 5 to 25 gallons per minute (Ohio Department of Natural Resources, Division of Water [no date]; Price and others, 1962; Wallace and others, 1969). The most productive ground-water sources in Area 11 are the sand and gravel deposits along the Ohio River. Wells along the Ohio River yield up to 1,500 gallons per minute (Kentucky Department of Natural Resources, 1965). 

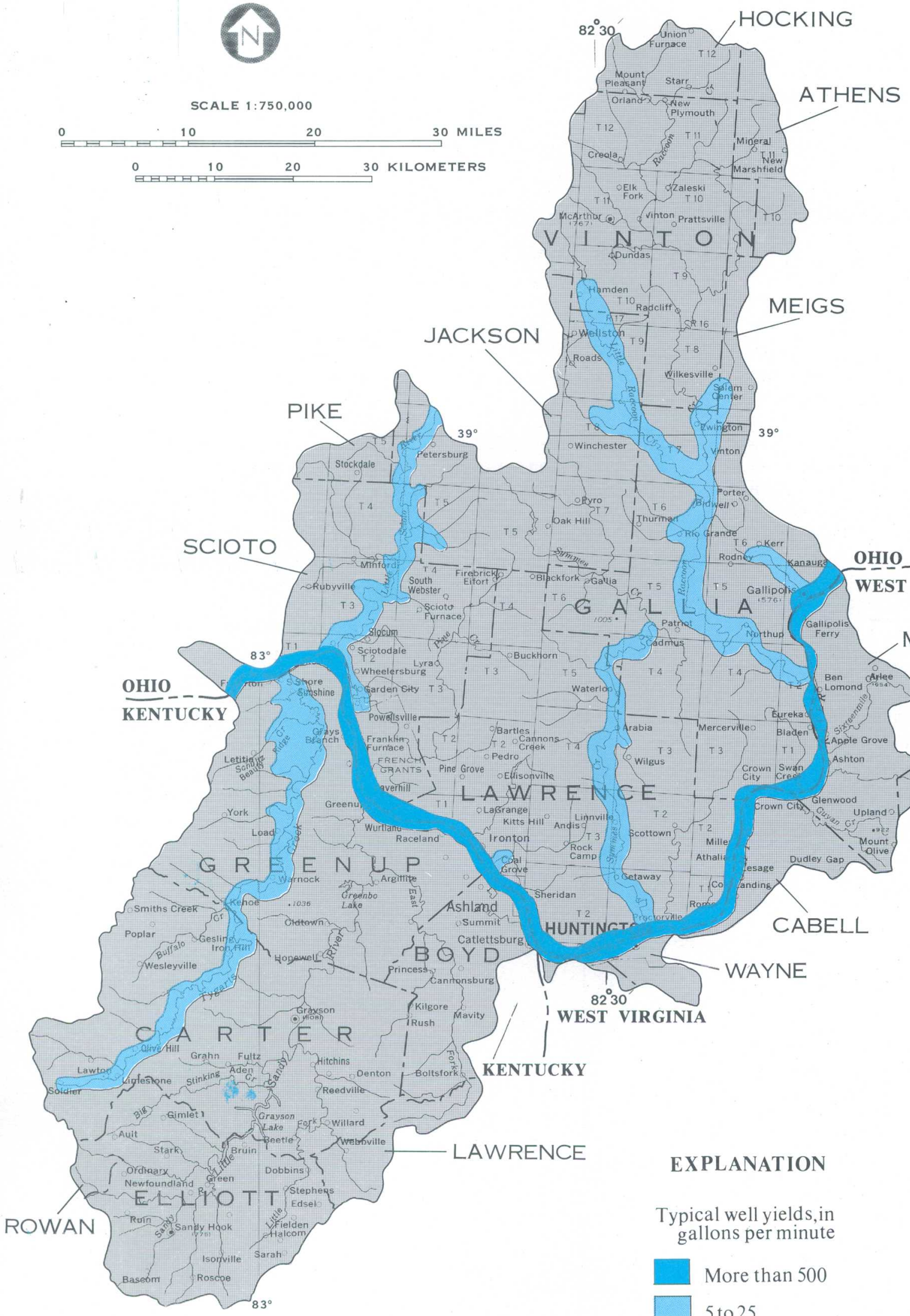

\section{EXPLANATION \\ Typical well yields, in gallons per minute \\ More than 500 \\ 5 to 25 \\ Less than 5}

BASE FROM U.S. GEOLOGICAL SURVEY

STATE BASE MAPS, $1973,1974,1975$

Figure 5.1-1 Ground-water well yields in A rea 11 (from Ohio Department of Natural Resouces, Division of water [no date]; Price and others, 1962; and Wallace and others, 1969) 


\title{
5.0 GROUND WATER--Continued \\ 5.2 Quality
}

\section{Bicarbonate, Calcium, and Sodium Ions Predominate in Ground Water}

\author{
Chemical analyses suggest that bicarbonate is the major anion in Area 11's \\ ground water; bicarbonate is commonly associated with calcium or sodium.
}

There is little published material describing the general quality of ground water in Area 11. The following discussion is based on studies of saline ground waters in Ohio (Sedam and Stein, 1970) and Kentucky (Hopkins, 1966). The well inventories for these studies included 23 sites in Area 11, 16 of which are in Kentucky and 7 of which are in Ohio; only bedrock wells were considered.

Chemical analyses of ground water suggest that the bicarbonate ion is the major anion in Area 11 and that calcium and sodium are the major cations. Sources of calcium in sandstone aquifers include the carbonate cement and associated limestone rocks. Sources of sodium are clays and associated shales.

Sulfate concentrations in water from wells were less than 500 milligrams per liter $(\mathrm{mg} / \mathrm{L})$. The highest concentration of manganese was $4.1 \mathrm{mg} / \mathrm{L}$. Iron concentrations in most of the wells exceeded 0.3 $\mathrm{mg} / \mathrm{L}$, which is the U.S. Environmental Protection Agency's suggested limit for iron in domestic water supplies (U.S. Environmental Protection Agency, 1976).

The dissolved-solids concentration in water from six wells was greater than $1,000 \mathrm{mg} / \mathrm{L}$; concentrations of 1,000 to $3,000 \mathrm{mg} / \mathrm{L}$ are considered to be "slightly saline." These concentrations were found in five of the wells at depths less than 100 feet. The dissolved-solids concentration and depth of well below ground surface at sites evaluated in Area 11 are shown in figure 5.2-1. 


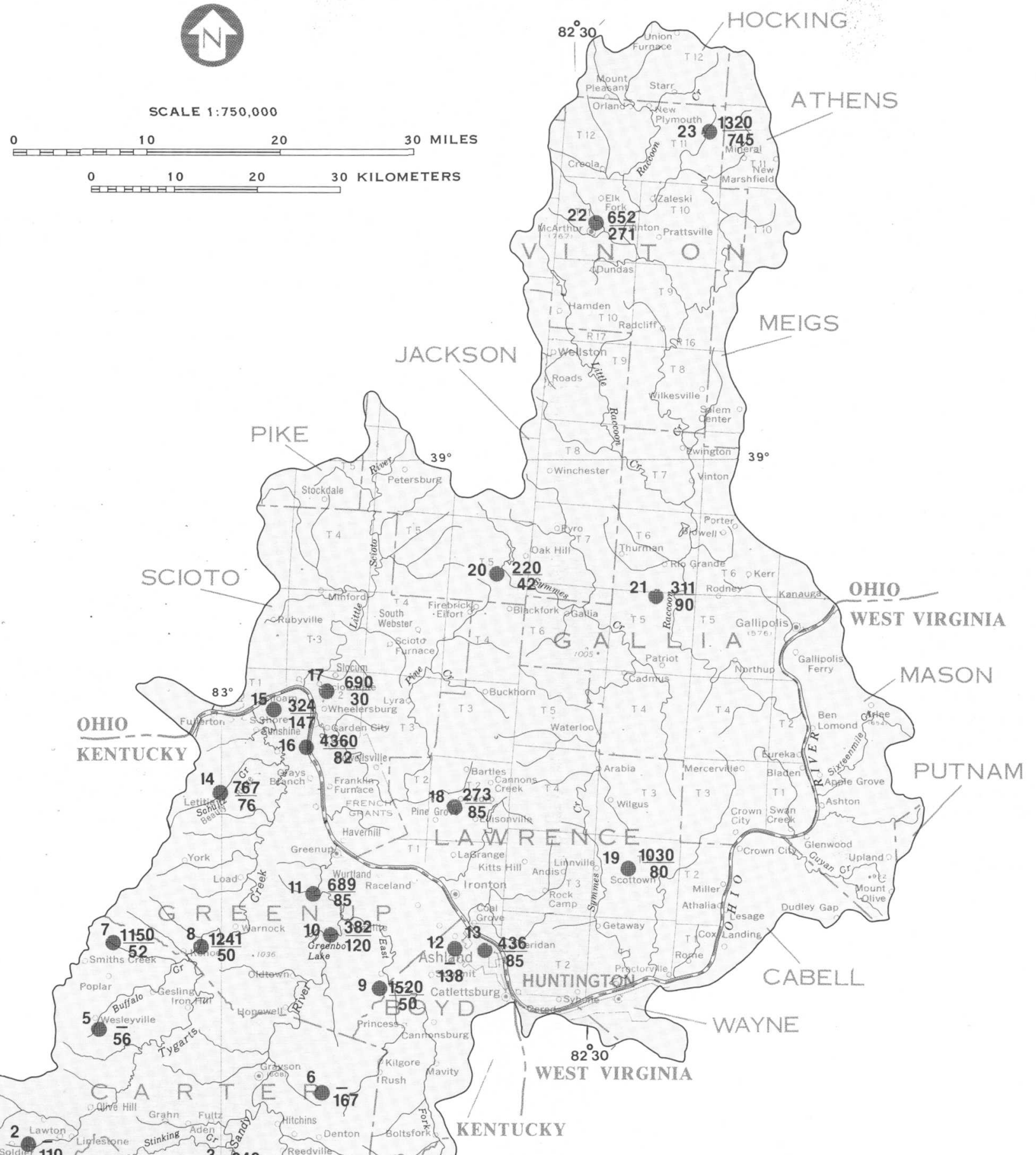

\section{EXPLANATION}

LAWRENCE

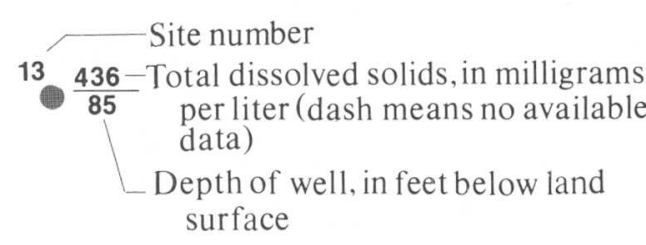

BASE FROM U.S. GEOLOGICAL SURVEY

STATE BASE MAPS, 1973, 1974, 1975

Figure 5.2-1 Dissolved solids concentrations in wells in Areall

(Data from Sedam and Stein, 1970; and Hopkins, 1966) 



\title{
6.0 WATER-DATA SOURCES \\ 6.1 Introduction
}

\section{NAWDEX, WATSTORE, OWDC Compile Water-Data Information}

\author{
Water data are collected nationwide by numerous organizations in response to a \\ wide variety of needs.
}

Three activities within the U.S. Geological Survey help to identify and provide access to a vast amount of water data.

(1) The National Water Data Exchange (NAWDEX) indexes the water data available from 400 organizations and provides help to those in need of water data.

(2) The National Water Data Storage and Retrieval System (WATSTORE) is the central repository of water data collected by the U.S. Geological Survey; it contains large volumes of data on the quantity and quality of both surface and ground waters.

(3) The Office of Water Data Coordination (OWDC) coordinates Federal water-data acquisition activities and maintains a "Catalog of Information on Water Data." Special indexes to the Catalog are being printed and made available to the public.

The three activities are explained further in sections $6.2,6.3$, and 6.4 


\author{
6.0 WATER-DATA SOURCES--Continued \\ 6.2 National Water Data Exchange (NAWDEX)
}

\title{
NAWDEX Simplifies Access to Water Data
}

\author{
The National Water Data Exchange (NAWDEX) is a nationwide program managed by \\ the U.S. Geological Survey to assist users of water data or water-related data \\ in identifying, locating, and acquiring needed data.
}

NAWDEX is a national confederation of wateroriented organizations working together to make their data more readily accessible and to facilitate a more efficient exchange of water data.

Services are available through a Program Office located at the U.S. Geological Survey's National Center in Reston, Virginia, and through a nationwide network of Assistance Centers located in 45 States and Puerto Rico, which provide local and convenient access to NAWDEX facilities. (See fig. 6.2-1.) A directory is available on request that provides names of organizations and persons to contact, addresses, telephone numbers, and office hours for each of these locations (Josefson and Blackwell, 1983).

NAWDEX can assist any organization or individual in identifying and locating needed water data and referring the requestor to the organization that retains the data required. To accomplish this service, NAWDEX maintains a computerized Master Water Data Index (fig. 6.2-2), which identifies sites for which water data are available, the type of data available for each site, and the organization retaining the data. A Water Data Sources Directory (fig. 6.2-3) also is maintained that identifies organizations that are sources of water data and the locations within these organizations from which data may be obtained. In addition, NAWDEX has direct access to some large water data bases of its members and has reciprocal agreements for the exchange of services with others.

Charges for NAWDEX services are assessed at the option of the organization providing the request- ed data or data service. Search assistance services are provided free by NAWDEX to the greatest extent possible. Charges are assessed, however, for those requests requiring computer cost, extensive personnel time, duplicating services, or other costs encountered by NAWDEX in the course of providing services. In all cases, charges assessed by NAWDEX Assistance Centers will not exceed the direct costs incurred in responding to the data request. Estimates of cost are provided by NAWDEX upon request and in all cases where costs are anticipated to be substantial.

For additional information concerning the NAWDEX program or its services contact:

\author{
Program Office \\ National Water Data Exchange (NAWDEX) \\ U.S. Geological Survey \\ 421 National Center \\ 12201 Sunrise Valley Drive \\ Reston, VA 22092 \\ Telephone: (703)860-6031 \\ FTS 928-6031 \\ Hours: 7:45-4:15 Eastern Time \\ NAWDEX ASSISTANCE CENTER \\ OHIO \\ U.S. Geological Survey \\ Water Resources Division \\ 975 West Third Avenue \\ Columbus, $\mathrm{OH} 43212$ \\ Telephone: (614)469-5553 \\ FTS 943-5553 \\ Hours: 7:45-4:30 Eastern Time
}




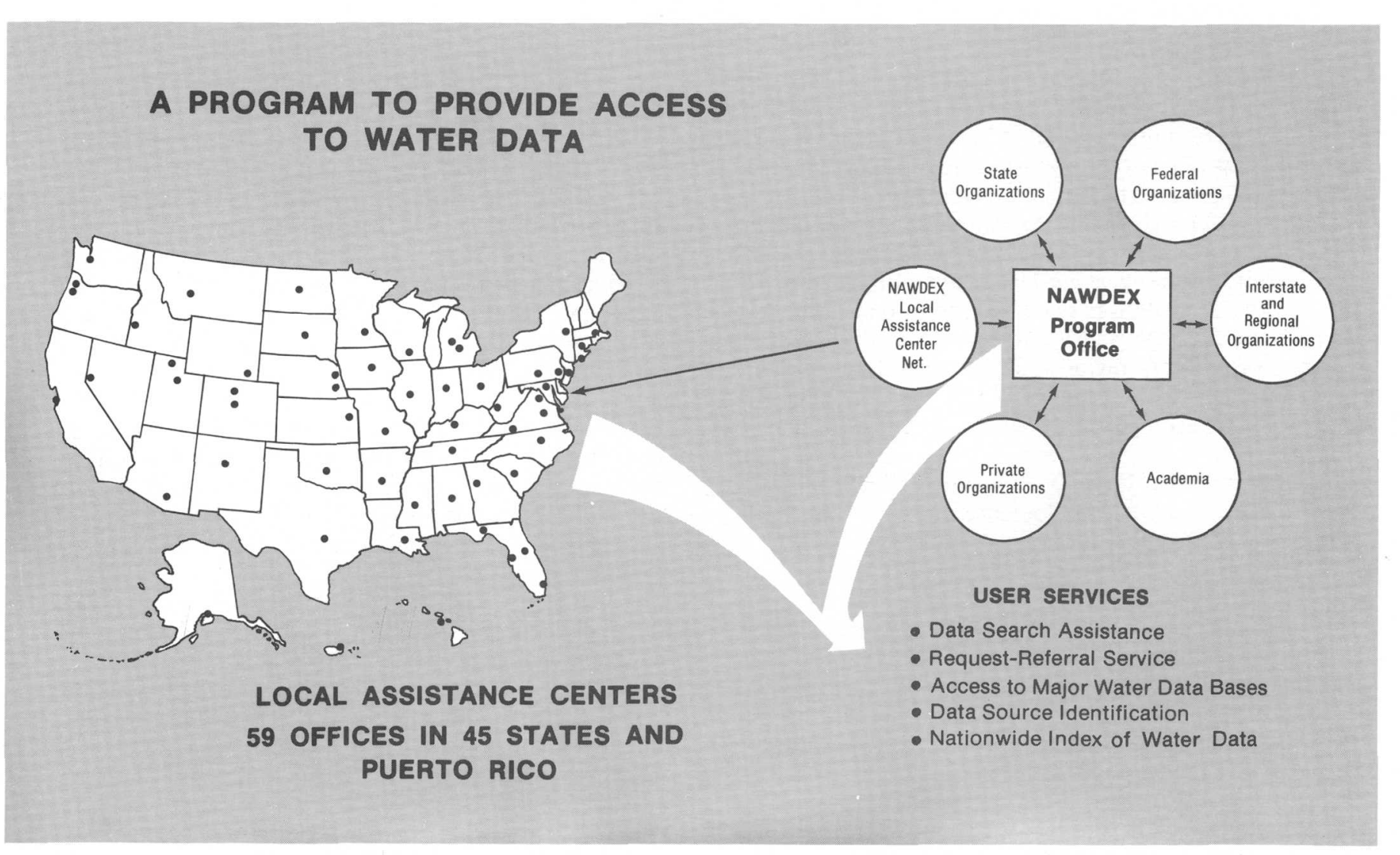

Figure 6.2-1 Access to water data.

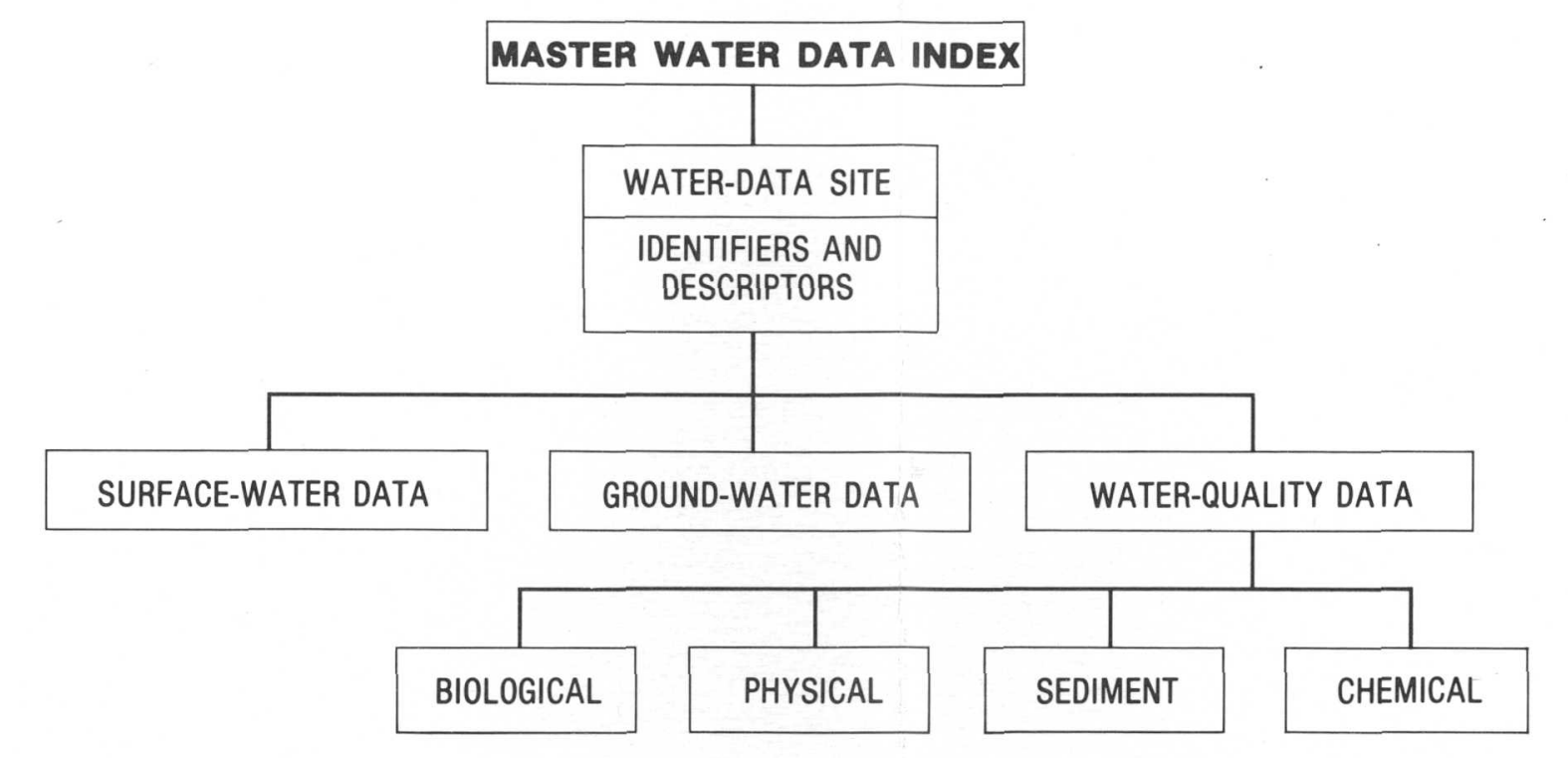

Figure 6.2-2 Master water-data index.

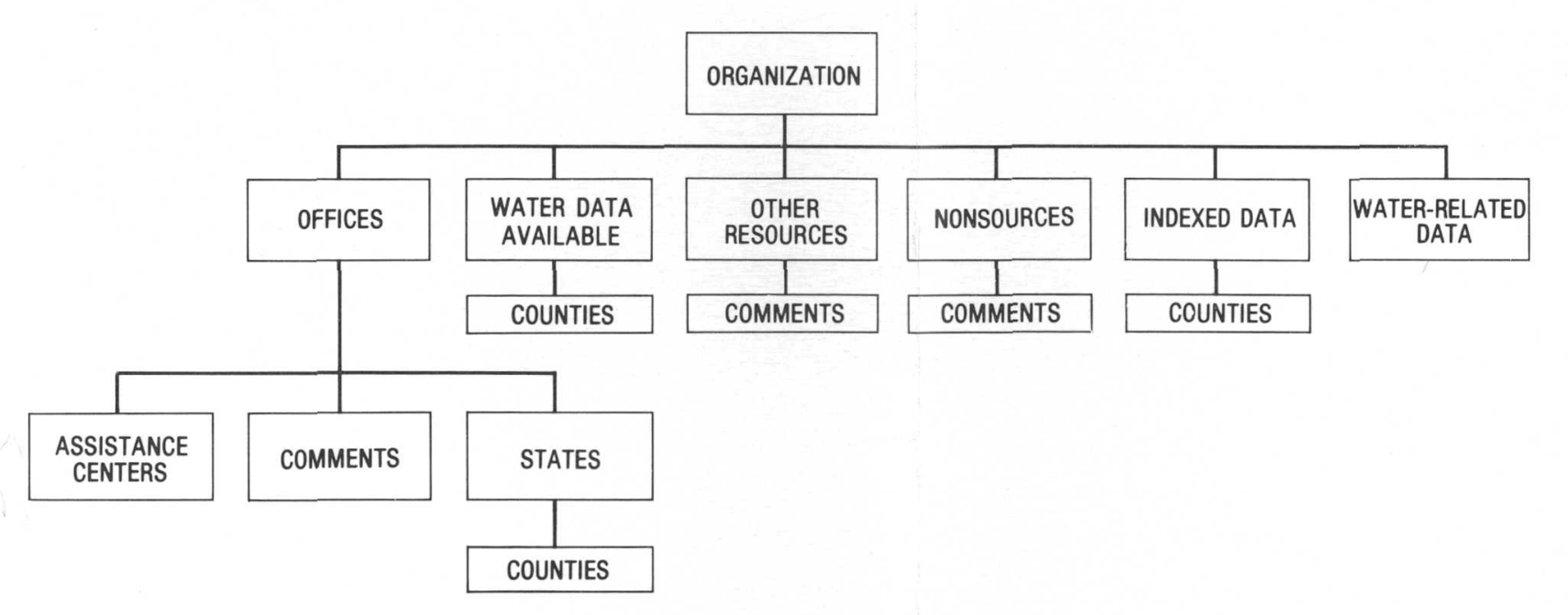

Figure 6.2-3 Water-data sources directory. 


\title{
6.0 WATER-DATA SOURCES--Continued 6.3 WATSTORE
}

\section{WATSTORE Automated Data System}

\author{
The National Water Data Storage and Retrieval System (WATSTORE) of the \\ U.S. Geological Survey provides computerized procedures and techniques for \\ processing water data and provides effective and efficient management of \\ data-releasing activities.
}

The National Water Data Storage and Retrieval System (WATSTORE) was established in November 1971 to computerize the U.S. Geological Survey's existing water-data system and to provide for more effective and efficient management of its datareleasing activities. The system is operated and maintained on the central computer facilities of the U.S. Geological Survey at its National Center in Reston, Va.; however, data may be entered into and retrieved from WATSTORE at a number of locations that are part of a nationwide telecomunication network. General inquiries about WATSTORE may be directed to U.S. Geological Survey district of fices or to:

\section{WATSTORE Program Office \\ U.S. Geological Survey \\ 437 National Center \\ Reston, VA 22092}

The U.S. Geological Survey currently (1983) collects data at approximately 17,000 stage- or discharge-gaging stations, 5,200 surface-water quality stations, 27,000 water-level observation wells, and 7,400 ground-water quality wells. Each year many water-data collection sites are added and others are discontinued; thus, large amounts of diversified data, both current and historical, are amassed by the Survey's data-collection activities.

Water data are used in many ways by decisionmakers for the management, development, and monitoring of our water resources. In addition to its data processing, storage, and retrieval capabilities, WATSTORE can provide a variety of useful products ranging from simple tables of data to complex statistical analyses. A minimal fee, plus the actual computer cost incurred in producing a desired product, is charged to the requestor.

The WATSTORE system consists of several files in which data are grouped and stored by common characteristics and data-collection frequencies. The system also is designed to allow for the inclusion of additional data files as needed. Currently, files are maintained for the storage of: (1) Surface-water, quality-of-water, and ground-water data measured on a daily or continuous basis; (2) annual peak values for streamflow stations; (3) chemical analyses for surface- and ground-water sites; (4) water parameters measured more frequently than daily; and (5) geologic and inventory data for ground-water sites. In addition, an index file of sites for which data are stored in the system is also maintained (fig. 6.3-1). A brief description of each file is as follows.

Station Header File: Information pertinent to the identification, location, and physical description of nearly 220,000 sites are contained in this file. All sites for which data are stored in the Daily-Values, Peak-Flow, Water-Quality, and Unit-Values files of WATSTORE are indexed in this file.

Daily-Values File: All water data measured or observed either on a daily or on a continuous basis and numerically reduced to daily values are stored in this file. Instantaneous measurements at fixed-time intervals, daily mean values, and statistics such as daily maximum and minimum value also may be stored. This file currently contains over 200 million daily values including data on streamflow, river stages, reservoir contents, water temperatures, specific conductance, sediment concentrations, sediment discharges, and ground-water levels.

Peak-Flow File: Annual maximum (peak) streamflow (discharge) and gage height (stage) values at surface-water sites comprise this file, which currently contains over 400,000 peak observations.

Water-Quality File: Results of more than 1.4 million analyses of water samples are contained in this file. These analyses contain data for as many as 185 different constituents and physical properties that describe the chemical, physical, biological, and radiochemical characteristics of both surface and ground waters. 
Unit-Values File: Water parameters measured on a schedule more frequent than daily are stored in this file. Rainfall, strean discharge, and temperature Unit-Values File.

Ground-Water Site-Inventory File: This file is maintained within WATSORE independent of the files discussed above, but it is cross-referenced to the Water-Quality File and the Daily-Values File. It contains inventory data about wells, springs, and site socation and identification, geohydrologic characteristics, well-construction history, and onetime field measurements such as water temperature. The file is designed to accommodate 225 data elements and currenly contains data for nearly 700,000

Remote Job Entry Sites: Almost all of the Water Resources Division's district offices are equipped with high-speed computer terminals for remote ac-
cess to the WATSTORE system. These terminals allow each site to enter data into or retrieve data from the system within an interval of several minutes to overnight, depending upon the priority placed on increased as the need arises.

Digital Transmission Sites: Digital recorders are used at many field locations to record values for parameters such as river stages, conductivity, water temperature, turbidity, wind direction, and chlorides. Data are recorded on 16-channel paper tape; are transmitted over telephone lines to the receiver a Reston, Va. The data are re-recorded on magnetic tape for use on the central computer. Extensive testing of satellite data-collection platforms has demonstrated their feasibility for transmitting realtime hydrologic data on a national scale. Battryto the satellite. About 500 data-relay stations are being operated currently (1983) by the Water Resources Division.

Central Laboratory System: The U.S. Geologi cal Survey's two water-quality laboratories, localed Ca 150,000 water amples per yar. Theselaborto- ries are equipped to perform chemical analyses the analyses range from determinaide, to complex organic compounds, such as pesticides. As each analysis is completed, the results are verified by laboratory personnel and transmitted via a computer terminal to the central computer facilities be stored in the Water-Quality File of WAT-

Computer-Printed Tables: Users most often request data from WATSTORE in the form of table printed by the computer. These tables may contain lists of actual data or condensed indexes that indicate the availability of data stored in the files. A variety formats is available to display the many types of

Computer-Printed Graphs: Computer-printed graphs for the rapid analysis or display of data are
another capability of WATSTORE. Computer programs are available to produce bar graphs (histograms), line graphs, frequency-distribution curves, $\mathrm{X}$-Y point plots, site-location map plots, and ther similar items by means of line printers.

Statistical Analyses: WATSTORE interfaces with a proprietary statistical package called the provide extensive analyses of data such as regressio analyses, analysis of variance, transformations, an correlations.

Digital Plotting: WATSTORE also makes use of software systems that prepare data for digital plot-
ting on peripheral offline plotters available at the central computer site. Plots that can be obtained include hydrographs, frequency-distribution curves, $\mathrm{X}-\mathrm{Y}$ point plots, contour plots, and three-dimensio al plots.

Data in Machine-Readable Form: Data stored in WATSTORE can be obtained in machine-readable form for use on other computers or for use as inpur to user-written computer programs. These data are available in the standard format of the WATSTORE system or in the form of punched cards or card

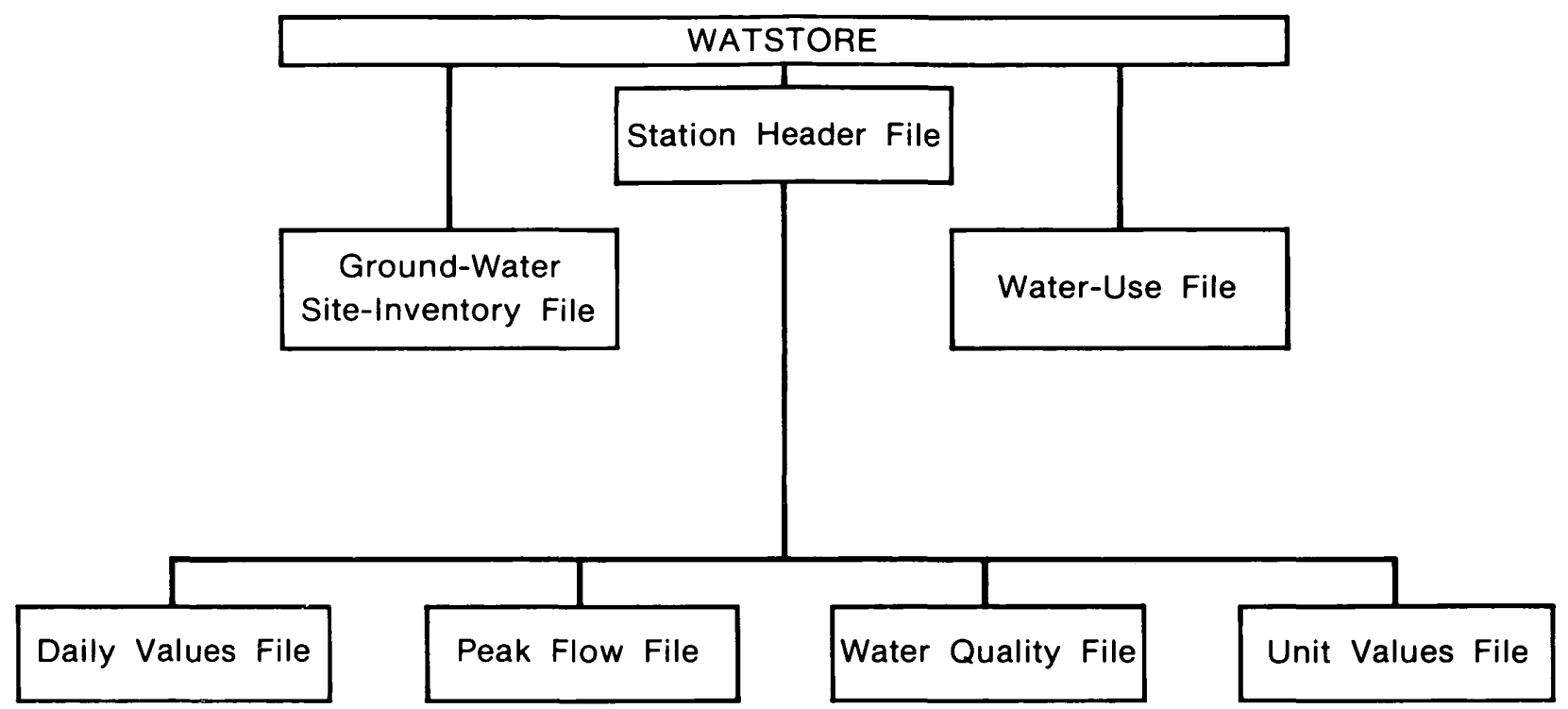

Figure 6.3-1 Index file stored dat 


\author{
6.0 WATER-DATA SOURCES--Continued \\ 6.4 Index to Water-Data Activities in Coal Provinces
}

\title{
Water Data Indexed for Coal Provinces
}

\author{
A special "Index to Water-Data Activities in Coal Provinces of the \\ United States," has been published by the U.S. Geological Survey's \\ Office of Water Data Coordination (OWDC).
}

The "Index to Water-Data Activities in Coal Provinces of the United States" was prepared to assist those involved in developing, managing, and regulating the Nation's coal resources by providing information on the availability of water-resources data in the major coal Provinces of the United States. It is derived from the "Catalog of Information on Water Data," which is a computerized information file about water-data-acquisition activities in the United States and its territories and possessions, with some international activities included.

This special index consists of five volumes (fig. 6.4-1): Volume I, Eastern Coal Province; volume II, Interior Coal Province; volume III, Northern Great Plains and Rocky Mountain Coal Provinces; volume IV, Gulf Coast Coal Provinces; and volume V, Pacific Coast and Alaska Coal Provinces. The information presented will aid the user in obtaining data for evaluating the effects of coal mining on water resources and in developing plans for meeting additional water-data needs. The report does not contain the actual data; rather, it provides information that will enable the user to determine if needed data are available.

Each volume of this special index consists of four parts: Part A, Streamflow and Stage Stations; Part B, Quality of Surface-Water Stations; Part C, Quality of Ground-Water Stations; and Part D, Areal Investigations and Miscellaneous Activities. Information given for each activity in Parts A-C includes: (1) The identifcation and location of the station, (2) the major types of data collected, (3) the frequency of data collection, (4) the form in which the data are stored, and (5) the agency or organization reporting the activity. Part D summarizes areal hydrologic investigations and water-data activities not included in the other parts of the index. The agencies that submitted the information, agency codes, and the number of activities reported by type are shown in a table. Those who need additional information from the catalog file or who need assistance in obtaining water data should contact the National Water Data Exchange (NAWDEX) (section 6.2).

Further information on the index volumes and their availability may be obtained from:

\author{
U.S. Geological Survey \\ Water Resources Division \\ 975 West Third Avenue \\ Columbus, $\mathrm{OH} 43212$ \\ Telephone: (614) 469-5553 \\ Office of Surface Mining \\ U.S. Department of the Interior \\ 1st Floor, Thomas Hill Bldg. \\ 950 Kanawha Blvd., East \\ Charleston, WV 25301 \\ Telephone: (304) 344-3481 \\ Office of Water Data Coordination \\ U.S. Geological Survey \\ National Center, Mail Stop 417 \\ Reston, VA 22092 \\ Telephone: (703) 860-6931
}




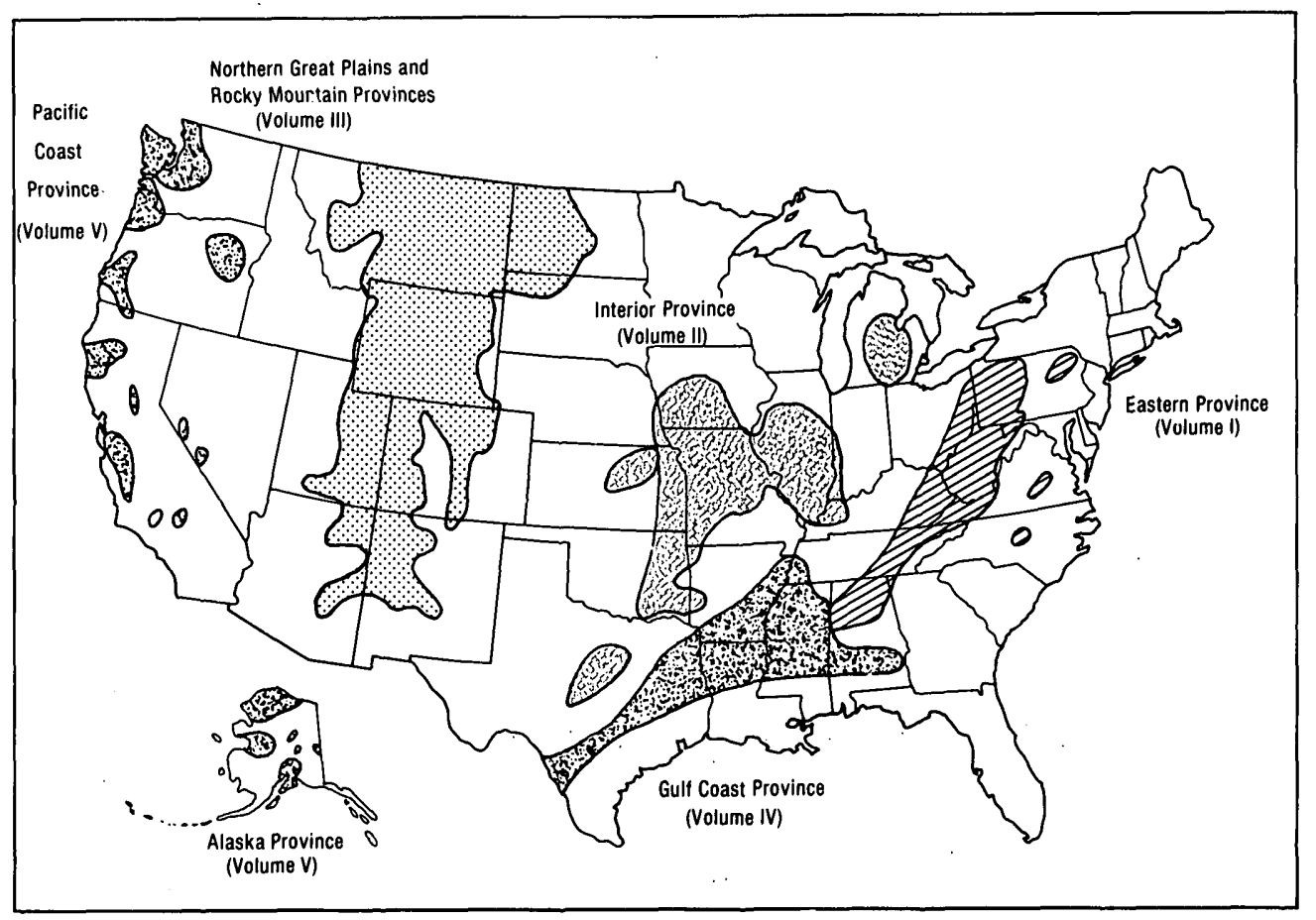

Figure 6.4-1 Index volumes and related provinces. 
Appendix 1.--U.S. Geological Survey Surface-Water Network in Area d1

\begin{tabular}{|c|c|c|c|c|c|c|c|c|c|c|}
\hline \multirow[b]{2}{*}{$\begin{array}{l}\text { Site } \\
\text { No. }\end{array}$} & \multirow[b]{2}{*}{$\begin{array}{l}\text { Station } \\
\text { No. }\end{array}$} & \multirow{2}{*}{\multicolumn{2}{|c|}{$\begin{array}{l}\text { Location } \\
\text { Latitude/Longitude }\end{array}$}} & \multirow[b]{2}{*}{ Station } & \multirow[b]{2}{*}{$\begin{array}{l}\text { Drainage } \\
\text { area } \\
\left(\mathrm{mi}^{2}\right)\end{array}$} & \multicolumn{4}{|c|}{ Dates of measurements } & \multirow[b]{2}{*}{$\begin{array}{l}\text { Type } \\
\text { of } \\
\text { site }\end{array}$} \\
\hline & & & & & & $\begin{array}{l}\text { Dis- } \\
\text { charge }\end{array}$ & $\begin{array}{l}\text { Chemical } \\
\text { quality }\end{array}$ & $\begin{array}{l}\text { Sedi- } \\
\text { ment }\end{array}$ & $\begin{array}{l}\text { Bio- } \\
\text { logi- } \\
\text { cal }\end{array}$ & \\
\hline 1 & 03216180 & 380514 & 0830728 & Little Sandy River at Sandy Hook, Ky. & -- & $1979-81$ & $1979-80$ & $1980-81$ & -- & PR \\
\hline 2 & 03216230 & 380922 & 0830946 & Big Caney Creek near Stark, Ky. & -- & $1979-81$ & $1979-81$ & $1980-81$ & -- & PR \\
\hline 3 & 03216370 & 381603 & 0830227 & Big Sinking Creek near Aden, Ky. & -- & $1979-81$ & $1979-81$ & $1980-81$ & -- & PR \\
\hline 4 & 03216430 & 380922 & 0825549 & Little Sandy River at Dobbins, Ky. & -- & $1979-81$ & $1979-80$ & $1980-81$ & -- & PR \\
\hline 5 & 03216450 & 381230 & 0825338 & Dry Fork at Willard, Ky. & -- & $1979-81$ & $1979-81$ & $1980-81$ & -- & PR \\
\hline 6 & 03216520 & 382038 & 0825709 & Beret Creek near Grayson, Ky. & -- & $1979-81$ & $1979-81$ & $1980-81$ & - & PR \\
\hline 7 & 03216558 & 382313 & 0824314 & $\begin{array}{l}\text { East Fork Little Sandy River } \\
\text { near Cannonsburg, } \mathrm{Ky} \text {. }\end{array}$ & -- & $1979-81$ & $1979-81$ & $1980-81$ & -- & PR \\
\hline 8 & 03216567 & 382304 & 0824450 & Williams Creek at Princess, Ky. & -- & $1979-81$ & $1979-81$ & $1980-81$ & -- & PR \\
\hline$\cdot 9$ & 03216800 & 381757 & 0831025 & Tygarts Creek at olive Hill, Ky. & 59.6 & $1957-81$ & $1979-81$ & $1980-81$ & -- & C \\
\hline 10 & 03216960 & 382530 & 0830520 & Buffalo Creek near Gesling, Ky. & -- & $1979-81$ & $1979-81$ & $1980-81$ & -- & PR \\
\hline 113 & 382842082235300 & 382842 & 0822353 & $\begin{array}{l}\text { Indian Guyan Creek near } \\
\text { Proctorville, Ohio }\end{array}$ & 18.8 & $1979-80$ & $1979-80$ & --- & 1979 & PR \\
\hline 123 & 382945082291700 & 382945 & 0822917 & $\begin{array}{l}\text { Leatherwood Creek near Chesapeake, } \\
\text { Ohio. }\end{array}$ & 4.0 & $1979-80$ & $1979-80$ & -- & 1979 & PR \\
\hline 133 & 382958082372400 & 382958 & 0823724 & $\begin{array}{l}\text { Little Ice Creek near Coal Grove, } \\
\text { Ohio. }\end{array}$ & 1.6 & $1979-81$ & $1979-81$ & $1979-81$ & 1979 & PR \\
\hline 143 & 383353082330600 & 383353 & 0823306 & Dog Fork at Kitts Hill, Ohio & 2.8 & $1979-80$ & $1979-80$ & -- & 1979 & PR \\
\hline 153 & 383640082352700 & 383640 & 0823527 & Paddle Creek near Kitts Hill, Ohio & 2.3 & $1979-80$ & $1979-80$ & --- & 1979 & PR \\
\hline 163 & 383644082313900 & 383644 & 0823139 & Sharps Creek near Kitts Hill, Ohio & 2.3 & $1979-80$ & $1979-80$ & -- & 1979 & PR \\
\hline 173 & 383657082124900 & 383657 & 0821249 & Swan Creek near Crown City, Ohio & 14.7 & $1979-80$ & $1979-80$ & -- & 1979 & PR \\
\hline 183 & 383726082500200 & 383726 & 0825002 & $\begin{array}{l}\text { Ginat Creek near Franklin Furnace, } \\
\text { Ohio. }\end{array}$ & 8.6 & $1979-80$ & $1979-80$ & --- & 1979 & PR \\
\hline 193 & 383750082435400 & 383750 & 0824354 & Little Pine Creek near Pedro, Ohio & 29.2 & $1979-80$ & $1979-80$ & --- & 1979 & PR \\
\hline 203 & 383842082272700 & 383842 & 0822727 & Long Creek near Waterloo, Ohio & 14.0 & $1979-80$ & $1970-80$ & --- & 1979 & PR \\
\hline 213 & 383944082292600 & 383944 & 0822926 & Aaron Creek near Waterloo, Ohio & 8.2 & $1979-80$ & $1979-80$ & --- & 1979 & PR \\
\hline 223 & 384149082315400 & 384149 & 0823154 & Buckeye Creek near Waterloo, Ohio & 6.7 & $1979-80$ & $1979-80$ & -- & 1979 & PR \\
\hline 23 & 384312082481700 & 384312 & 0821450 & Lick Run near Wheelersburg, Ohio & 4.4 & $1979-80$ & $1979-80$ & -- & 1979 & PR \\
\hline 243 & 384401082145000 & 384401 & 0821450 & Bullskin Creek near Gallipolis, Ohio & 14.4 & $1979-80$ & $1979-80$ & $1979-80$ & 1979 & PR \\
\hline 253 & 384452082181400 & 384452 & 0821814 & Claylick Run near Northup, Ohio & 4.8 & $1979-81$ & $1979-81$ & 1981 & 1979 & PR \\
\hline 263 & 384454082223500 & 384454 & 0822235 & $\begin{array}{l}\text { Sand Fork Symmes Creek near } \\
\text { Water } 100, \text { Ohio. }\end{array}$ & 37.1 & $1979-80$ & $1979-80$ & --- & 1979 & PR \\
\hline 273 & 384603082503400 & 384603 & 0825034 & Wards Run near Minford, Ohio & 7.4 & $1979-80$ & $1979-80$ & --- & 1979 & PR \\
\hline 283 & 384817082391600 & 384817 & 0823916 & Brady Run near South Webster, Ohio & 6.1 & $1979-81$ & $1979-81$ & 1981 & 1979 & PR \\
\hline 293 & 394841082464000 & 384841 & 0824640 & Frederick Creek near Minford, Ohio & 9.4 & $1979-80$ & $1979-80$ & --- & 1979 & PR \\
\hline 30 & 385007082305100 & 385007 & 0823051 & Dirty Face Creek near Gallia, Ohio & 13.1 & $1979-80$ & $1979-80$ & $-\cdots$ & 1979 & PR \\
\hline 31 & 385027082131800 & 385027 & 0821318 & $\begin{array}{l}\text { Chickamauga Creek near Gallipolis, } \\
\text { Ohio. }\end{array}$ & 19.4 & $1979-80$ & $1979-80$ & -- & 1979 & PR \\
\hline 32 & 38511708250090 & 385117 & 0825009 & Long Run near Minford, Ohio & 17.9 & $1979-80$ & $1979-80$ & --- & 1979 & PR \\
\hline 33 & 385316082521200 & 385316 & 0825212 & McConnel Creek near Stockdale, Ohio & 10.2 & $1979-80$ & $1979-80$ & --- & 1979 & PR \\
\hline 34 & 385334082225800 & 385334 & 0822258 & Little Indian Creek near Rio Grande, & 10.3 & $1979-80$ & $1979-80$ & -- & 1979 & PR \\
\hline 35 & 385405082431000 & 385405 & 0824310 & $\begin{array}{l}\text { Holland Fork tributary near } \\
\text { South Webster, Ohio. }\end{array}$ & 8.3 & $1979-80$ & $1979-80$ & --- & 1979 & PR \\
\hline 36 & 385406082450600 & 385406 & 0824506 & Bucklick Creek near Stockdale, Ohio & 6.7 & $1979-80$ & $1979-80$ & $-\cdots$ & 1979 & PR \\
\hline 37 & 385412082191300 & 385412 & 0824913 & Barren Creek near Harrisburg, Ohio & 7.2 & $1979-80$ & $1979-80$ & --- & 1979 & PR \\
\hline 38 & 385740082430200 & 385740 & 0824302 & Sugarcamp Creek near Stockdale, Ohio & 3.7 & $1979-80$ & $1979-80$ & -- & 1979 & PR \\
\hline 39 & 385809082474400 & 385809 & 0824744 & McDowell Creek near stockdale, Ohio & 6.5 & $1979-80$ & $1979-80$ & -- & 1979 & PR \\
\hline
\end{tabular}




\begin{tabular}{|c|c|c|c|c|c|c|c|c|c|c|}
\hline & & & & & & & Dates of $m$ & asurement & & \\
\hline $\begin{array}{l}\text { Site } \\
\text { No. }\end{array}$ & $\begin{array}{l}\text { Station } \\
\text { No. }\end{array}$ & Lat itude/ & $\frac{\text { tion }}{\text { Longitude }}$ & Station & $\begin{array}{l}\text { Drainage } \\
\text { areaa } \\
\left(\mathrm{mi}^{2}\right)\end{array}$ & $\begin{array}{l}\text { Dis- } \\
\text { charge }\end{array}$ & $\begin{array}{l}\text { Chemical } \\
\text { quality }\end{array}$ & $\begin{array}{l}\text { Sedi- } \\
\text { ment }\end{array}$ & $\begin{array}{l}\text { Bio- } \\
\operatorname{logi-} \\
\text { cal s }\end{array}$ & $\begin{array}{l}\text { Type } \\
\text { of } \\
\text { site }\end{array}$ \\
\hline 403 & 390024082281200 & 390024 & 0822812 & Dickason Run near Thurman, Ohio & 22.5 & $1979-81$ & $1979-81$ & 1981 & 1979 & PR \\
\hline 413 & 390053082201000 & 390053 & 0822010 & Strongs Road near Ewington, Ohio & 15.7 & $1979-80$ & $1979-80$ & --- & 1979 & PR \\
\hline 423 & 390634082313600 & 390634 & 0823136 & Meadow Run at Wellston, Ohio & 8.6 & $1979-80$ & $1979-80$ & --- & 1979 & PR \\
\hline 433 & 390828082224900 & 390828 & 0822249 & Pierce Run near Radcliff, Ohio & 9.7 & $1979-81$ & $1979-81$ & 1981 & 1979 & PR \\
\hline 443 & 391435082281800 & 391435 & 0822818 & Puncheon Fork at McArthur, Ohio & 9.4 & $1979-80$ & $1979-81$ & $-\cdots$ & 1979 & PR \\
\hline 453 & 392001082195601 & 392001 & 0821956 & Sandy Run near Zaleski, Ohio & 5.0 & $1979-81$ & $1979-81$ & 1981 & 1979 & PR \\
\hline 463 & 391915082274600 & 391915 & 0822746 & Brushy Fork near Creola, Ohio & 25.4 & $1979-81$ & $1979-81$ & $1979-81$ & 1979 & PR \\
\hline 47 & 03201600 & 392001 & 0821956 & Sandy Run near Lake Hope, Ohio & 5.0 & $1958-78$ & $\begin{array}{l}1959-61 \\
1970-78\end{array}$ & -- & -- & $\mathrm{c}$ \\
\hline 483 & 392348082220200 & 392348 & 0822202 & $\begin{array}{l}\text { East Branch Raccoon Creek near } \\
\text { New Plymouth, Ohio. }\end{array}$ & 14.5 & $1979-81$ & $1979-81$ & $1979-81$ & 1979 & PR \\
\hline 493 & 392350082255200 & 392350 & 0822552 & Honey Fork near New Plymouth, Ohio & 9.5 & $1979-80$ & $1979-81$ & -- & 1979 & PR \\
\hline 50 & 03217000 & 393351 & 0825708 & Tygarts Creek near Greenup, Ky. & 242 & $1940-81$ & $\begin{array}{l}1957-75 \\
1979-81\end{array}$ & $\begin{array}{l}1957-73 \\
1979-81\end{array}$ & --- & c \\
\hline 51 & 03216500 & 381948 & 0825622 & Little Sandy River at Grayson, Ky. & 400 & $1938-81$ & $\begin{array}{l}1951-75 \\
1979-81\end{array}$ & $1979-81$ & --- & c \\
\hline 52 & 03202000 & 385225 & 0822122 & Raccoon Creek at Adamsville, Ohio & 585 & $\begin{array}{l}1915-36 \\
1939-81\end{array}$ & $\begin{array}{l}1951-54 \\
1964-81\end{array}$ & $\begin{array}{l}1969-74 \\
1980-81\end{array}$ & 1980 & c \\
\hline 53 & 03201600 & 392145 & 0821847 & $\begin{array}{l}\text { Sandy Run above Big Four Hollow } \\
\text { Creek near Lake Hope, Ohio. }\end{array}$ & 0.98 & $1971-81$ & $1971-81$ & $1979-81$ & 1980 & $\mathrm{c}$ \\
\hline 54 & 03216540 & 381401 & 0824232 & $\begin{array}{l}\text { East Fork Little Sandy River } \\
\text { near Fallsburg, ky. }\end{array}$ & 12.2 & $1973-81$ & $1977-81$ & -- & --- & $\mathrm{c}$ \\
\hline 55 & 03216350 & 381514 & 0825928 & $\begin{array}{l}\text { Little Sandy River below } \\
\text { Grayson Dam near Leon, KY. }\end{array}$ & 196 & $1967-81$ & $1970-71$ & -- & --- & C \\
\hline 56 & 03216400 & 381711 & 0825839 & $\begin{array}{l}\text { Little Sandy River at } \\
\text { Leon, } \mathrm{Ky} \text {. }\end{array}$ & 255 & $1962-81$ & $1970-71$ & -- & --- & $\mathrm{C}$ \\
\hline 57 & 03206000 & 382448 & 0823002 & Ohio River at Huntington, w.Va. & 5,900 & $1934-81$ & -- & --- & $\cdots$ & C \\
\hline 58 & 03216000 & 382852 & 0823812 & Ohio River at Ashland, Ky. & 0,750 & $1938-75$ & $-\cdots$ & -- & -- & $\mathrm{C}$ \\
\hline 59 & 03216600 & 383848 & $0825138^{\circ}$ & Ohio River at Greenup Dam, Ky. & 2,000 & 1969-8I: & $1975-81$ & $1975-81$ & 1980 & $c$ \\
\hline 60 & 03201722 & 392130 & 0821904 & $\begin{array}{l}\text { Sandy Run below Hull Hollow Creek } \\
\text { near Lake Hope, Ohio. }\end{array}$ & 2.3 & $1979-80$ & $1979-80$ & -- & $-\infty$ & $c$ \\
\hline 61 & 03201720 & 392132 & 0821905 & $\begin{array}{l}\text { Hull Hollow Creek near Lake Hope, } \\
\text { Ohio. }\end{array}$ & 0.22 & $1979-81$ & $1979-81$ & $1979-81$ & -- & $\mathrm{c}$ \\
\hline 62 & 03201700 & 392148 & 0821851 & $\begin{array}{l}\text { Big Four Hollow Creek near Lake } \\
\text { Hope, Ohio. }\end{array}$ & 1.0 & $1971-81$ & $1971-81$ & -- & --- & C \\
\hline 63 & 03201660 & 392212 & 0821906 & $\begin{array}{l}\text { Big Four Hollow Creek below East Fork } \\
\text { near Lake Hope, Ohio. }\end{array}$ & 0.73 & $1979-81$ & $1971-81$ & --- & --- & $c$ \\
\hline 64 & 03205995 & 382503 & 0823036 & Sandusky Creek near Burlington, Ohio & 0.73 & $1978-80$ & --- & $-\cdots$ & --- & PR \\
\hline 65 & 03216050 & 383105 & 0823809 & Ice Creek at Ironton, Ohio & 37.2 & $1976-78$ & $1976-77$ & --- & -- & PR \\
\hline 66 & 03201550 & 392346 & 0822049 & Starr Run near New Plymouth, Ohio & 0.30 & $1978-80$ & --- & $-\cdots$ & --- & PR \\
\hline 67 & 03205210 & 382841 & 0822354 & Indian Guyan Creek near Bradrick, Ohio & $\circ \quad 67.5$ & 1959 & 1980 & -- & -- & PR \\
\hline 68 & 03201990 & 385712 & 0822157 & $\begin{array}{l}\text { Little Raccoon Creek near Vinton, } \\
\text { Ohio. }\end{array}$ & 154 & $\begin{array}{l}1941-53 \\
1959,1965 \\
1972-75\end{array}$ & $\begin{array}{l}1959-65 \\
1972-75 \\
1980\end{array}$ & -- & -- & $\mathrm{PR}$ \\
\hline 69 & 03201900 & 391420 & 0821710 & Raccoon Creek near Prattsville, Ohio & 200 & $1951-71$ & 1980 & --- & --- & PR \\
\hline
\end{tabular}

1 C, continuous-record station; PR, partial-record site. 


\begin{tabular}{|c|c|c|c|c|c|}
\hline $\begin{array}{l}\text { Site } \\
\text { No. }\end{array}$ & $\begin{array}{l}\text { Station } \\
\text { No. }\end{array}$ & Station & $\begin{array}{l}\text { Drainage } \\
\text { area } \\
\text { (square } \\
\text { miles) } \\
\text { [l] }\end{array}$ & $\begin{array}{l}\text { Mean annual } \\
\text { discharge } \\
\text { (cubic feet } \\
\text { per second) } \\
\text { [2] }\end{array}$ & $\begin{array}{l}\text { 7-day, } \\
\text { l0-year } \\
\text { low flow } \\
\text { (cubic feet } \\
\text { per second) } \\
\text { [3] }\end{array}$ \\
\hline 53 & 03201600 & $\begin{array}{l}\text { Sandy Run above Big Four Hollow } \\
\text { Creek near Lake Hope, Ohio. }\end{array}$ & 0.98 & 1.14 & -- \\
\hline 62 & 03201700 & $\begin{array}{l}\text { Big Four Hollow Creek near } \\
\text { Lake Hope, Ohio. }\end{array}$ & 1.0 & 1.17 & -- \\
\hline 47 & 03201800 & Sandy Run near Lake Hope, Ohio & 5.0 & 5.73 & 0 \\
\hline 69 & 03201800 & $\begin{array}{l}\text { Raccoon Creek near Prattsville, } \\
\text { Ohio. }\end{array}$ & 200 & -- & 0.1 \\
\hline 68 & 03205210 & $\begin{array}{l}\text { Little Raccoon Creek near Vinton, } \\
\text { Ohio. }\end{array}$ & 154 & -- & 1.3 \\
\hline 52 & 03202000 & $\begin{array}{l}\text { Raccoon Creek near Adamsville, } \\
\text { Ohio. }\end{array}$ & 585 & 655 & 3.5 \\
\hline 67 & 03205210 & $\begin{array}{l}\text { Indian Guyan Creek near Bradrick, } \\
\text { Ohio. }\end{array}$ & 67.5 & -- & 0 \\
\hline 55 & 03216350 & $\begin{array}{l}\text { Little Sandy River below Grayson } \\
\text { Dam near Leon, Ky. }\end{array}$ & 196 & 252 & 12.6 \\
\hline 56 & 03216400 & Little Sandy River at Leon, Ky. & 255 & 301 & 17.3 \\
\hline 51 & 03216500 & Little Sandy River at Grayson, Ky. & 400 & 478 & 18.1 \\
\hline 54 & 03216540 & $\begin{array}{l}\text { East Fork Little Sandy River near } \\
\text { Fallsburg, } \mathrm{Ky} \text {. }\end{array}$ & 12.2 & 16.3 & 0 \\
\hline 9 & 03216800 & Tygarts Creek at olive Hill, Ky. & 59.6 & 87.7 & 0 \\
\hline 50 & 03217000 & Tygarts Creek near Greenup, Ky. & 242 & 307 & 0.3 \\
\hline
\end{tabular}

\footnotetext{
$I_{R}$, regulated flow; $U$, unregulated flow
} 


\begin{tabular}{|c|c|c|c|c|c|c|}
\hline $\begin{array}{l}\text { 2-year peak } \\
\text { discharge } \\
\text { (cubic feet } \\
\text { per second) } \\
\text { [4] }\end{array}$ & $\begin{array}{l}\text { 50-percent } \\
\text { duration } \\
\text { discharge } \\
\text { (cubic feet } \\
\text { per second) } \\
{[5]}\end{array}$ & $\begin{array}{c}\text { Mean annual } \\
\text { discharge } \\
\text { (cubic feet } \\
\text { per second per } \\
\text { square mile) } \\
{[6]}\end{array}$ & $\begin{array}{l}\text { 7-day, } \\
\text { lo-year } \\
\text { low flow } \\
\text { (cubic feet } \\
\text { per second per } \\
\text { square mile) } \\
\text { [7] }\end{array}$ & $\begin{array}{l}\text { 2-year } \\
\text { peak dis- } \\
\text { charge (cubic } \\
\text { feet per } \\
\text { second per } \\
\text { square mile) } \\
\text { [8] }\end{array}$ & $\begin{array}{l}\text { 50-percent } \\
\text { duration dis- } \\
\text { charge (cubic } \\
\text { feet per } \\
\text { second per } \\
\text { square mile) } \\
\text { [9] }\end{array}$ & $\begin{array}{l}\text { Type } \\
\text { of } \\
\text { flow } 1 \\
{[10]}\end{array}$ \\
\hline-- & -- & 1.16 & -- & -- & -- & U \\
\hline-- & -- & 1.17 & - & -- & -- & $\mathrm{U}$ \\
\hline 690 & 1.50 & 1.15 & 0 & 138 & 0.30 & $\mathrm{U}$ \\
\hline-- & -- & -- & 0.001 & -- & - & $\mathrm{U}$ \\
\hline-- & -. & - & 0.008 & - & - & $\mathrm{U}$ \\
\hline 6,350 & 210 & 1.12 & 0.006 & 10.8 & 0.36 & $\mathrm{U}$ \\
\hline-- & -- & -- & 0 & -- & -- & u \\
\hline-- & 90 & 1.28 & 0.064 & -- & 0.46 & $\mathrm{R}$ \\
\hline 5,570 & 100 & 1.18 & 0.068 & 21.8 & 0.39 & $R$ \\
\hline 9,960 & 140 & 1.19 & 0.045 & 24.9 & 0.35 & $\mathrm{R}$ \\
\hline 869 & 4.4 & 1.33 & 0 & 71.2 & 0.36 & $\mathrm{u}$ \\
\hline 5,224 & 28 & 1.47 & 0 & 87.5 & $0.47^{\prime}$ & $\mathrm{U}$ \\
\hline 7,490 & 86 & 1.26 & 0.001 & 31.0 & 0.36 & $\mathrm{U}$ \\
\hline
\end{tabular}




\subsection{SELECTED REFERENCES}

Anttila, P. W., and Tobin, R. L., 1978, Fluvial sediment in Ohio: U.S. Geological Survey Water-Supply Paper 2045, 58 p.

Bernhagen, R. J., 1947, Ground water in Ohio: Ohio State University, Engineering Experiment Station News, v. 19, no. 2, p. 60-67.

Bownocker, J. A., compiler, 1929, Geologic map of Ohio, scale 1:500,000: Ohio Department of Natural Resources Division of Geological Survey, 1 pl.

Bownocker, J. A., and Dean, E. A., 1929, Analysis of the coals of Ohio: Ohio Department of Natural Resources Division of Geological Survey Bulletin 34, 360 p.

Brant, R. A., 1956, Coal resources of the upper part of the Allegheny Formation in Ohio: Ohio Department of Natural Resources Division of Geological Survey Report of Investigations 29, $68 \mathrm{p}$.

Brant, R. A., and DeLong, R. M., 1960, Coal resources of Ohio: Ohio Department of Natural Resources Division of Geological Survey Bulletin 58, p. 129-130.

Collins, H. R., 1976, Coal production in Ohio, 1800-1974: Ohio Department of Natural Resources Division of Geological Survey Circular $44,33 \mathrm{p}$.

1978, Seam analysis and description of U.S. coal fields, Ohio, in Neilson, G. F., ed., 1978 Keystone Coal Industry Manual: New York, McGraw-Hill, p. 532-534.

Cross, W. P., 1963, Low-flow frequencies and storage requirements for selected Ohio streams: Ohio Department of Natural Resources Division of Water Bulletin 37, $66 \mathrm{p}$.

1965, Low-flow frequency and storage requirement indices for Ohio streams: Ohio Department of Natural Resources Division of Water Bulletin 40, $47 \mathrm{p}$.

1967, Drainage areas of Ohio streams, supplement to gazetteer of Ohio streams: Ohio Department of Natural Resources Division of Water, Water Plan Inventory Report 12a, $61 \mathrm{p}$. 1968, Flow duration of Ohio streams based on gaging-station records through 1965: Ohio Department of Natural Resources Division of Water Bulletin 42, $68 \mathrm{p}$.

Cross, W. P., and Hedges, R. E., 1959, Flow duration of Ohio streams: Ohio Department of Natural Resources Division of Water Bulletin 31, 152 p.

Dalrymple, Tate, 1960, Flood-frequency analysis, manual of hydrology: U.S. Geological Survey Water-Supply Paper 1543-A, 80 p.
Engelke, M. J., Jr., Roth, D. K., and others, 1981, Hydrology of Area 7, Eastern Coal Province, Ohio: U.S. Geological Survey Water-Resources Investigations Open-File Report 81-815, 60 p.

Fenneman, N. M., 1938, Physiographic divisions of the United States (3rd ed.): Associated American Geographers Annuals, v. 18, no. 4, p. 261-353.

Garrels, R. M., and Christ, C. L., 1965, Solutions, minerals, and equilibria: New York, Harper and Row, $450 \mathrm{p}$.

Goldschmidt, V. M., and Muir, Alex (editor), 1958, Geochemistry: Oxford University Press, $730 \mathrm{p}$.

Hannum, C. H., 1976, Technique for estimating magnitude and frequency of floods in Kentucky: U.S. Geological Survey Water-Resources Investigations 76-62, $70 \mathrm{p}$.

Hart, C. W., Jr., and Fuller, S. L. H., 1974, Pollution ecology of freshwater invertebrates (1st ed.): New York, Academic Press, 314 p.

Harvard University, 1970, Oxygenation of ferrous iron: Federal Water Quality Administration, Water Pollution Control Research Ser. 14010, 06/69.

Hem, J. D., 1970, Study and interpretation of the chemical characteristics of natural water $(2 \mathrm{~d}$ ed.): U.S. Geological Survey Water-Supply $\mathrm{Pa}$ per $1473,363 \mathrm{p}$.

Hopkins, H. T., 1966, Fresh-saline water interface map of Kentucky: Kentucky Geological Survey, Ser. X, 1 pl.

Johnson, D. P., and Metzker, K. D., 1981, Low-flow characteristics of Ohio streams: U.S. Geological Survey Open-File Report 81-1195, 285 p.

Josefson, B. M., and Blackwell, C. D., 1983, Directory of assistance centers of the National Water Data Exchange (NAWDEX): U.S. Geological Survey Open-File Report 83-262, 33 p.

Kentucky Department of Mines and Minerals, 1978, Annual report.

Kentucky Department of Natural Resources, 1965, Kentucky water resources -- 1965: $79 \mathrm{p}$.

Krebs, C. E., and Teets, D. D., Jr., 1913, West Virginia Geological Survey--Cabell, Wayne, and Lincoln Counties: West Virginia Geological Survey, $483 \mathrm{p}$.

Landers, R. A., 1976, A practical handbook for individual water-supply systems in West Virginia: West Virginia Geologic and Economic Survey, $102 \mathrm{p}$.

Langbein, W. B., and Iseri, K. T., 1960, Manual of hydrology, general introduction and hydrologic definitions: U.S. Geological Survey WaterSupply Paper 1541-A, 29 p. 
McKee, J. E., and Wolf, H. W., editors, 1976, Water quality criteria: California Water Resources Control Board Publication 3-A, 548 p.

Murchison, D., and Westoll, T. S., editors, 1968, Coal and coal-bearing strata: New York, Elsevier.

National Academy of Sciences, National Academy of Engineering, 1973, [1974], Water quality criteria: Washington, D. C., U.S. Government Printing Office, $594 \mathrm{p}$.

Noble, A. G., and Korsok, A. J., 1975, Ohio--an American heartland: Ohio Department of Natural Resources Division of Geological Survey Bulletin 65, 230 p.

Ohio Board on Unreclaimed Strip-Mined Lands, 1974, Land reborn: Ohio Department of Natural Resources, $91 \mathrm{p}$.

Ohio Department of Industrial Relations, Division of Mines [1975-1979], Annual reports.

Ohio Department of Natural Resources, Capability Analysis Program, 1981, Land use maps.

Ohio Department of Natural Resources Division of Lands and Soil, 1973, Know Ohio's soil regions: map, scale 1: 500,000, $1 \mathrm{pl}$.

Ohio Department of Natural Resources Division of Water, [no date], Ground-water resources in Ohio: map, scale 1 in. $=10 \mathrm{mi}, 1 \mathrm{pl}$.

1962, Ohio hydrologic atlas: Ohio Water Plan Inventory Report 13, 4 pl.

1973, Principal streams and their drainage areas: map, scale 1 in. $=10 \mathrm{mi}, 1 \mathrm{pl}$.

1977, Ohio's land use: Miscellaneous Report 20

Ohio Environmental Protection Agency, 1977, Water quality standards: Chapter 3745.1 of the Administrative Code, $117 \mathrm{p}$.

Pennak, R. W., 1953; Fresh-water invertebrates of the United States (1st ed.): New York, Ronald Press, p. 435-692.

Price, W. E., Jr., Kilburn, Chabot, and Mull, D. S., 1962, Availability of ground water in Boyd, Carter, Eliot, Greenup, Johnson, Lawrence, Lee, Menifee, Morgan, and Wolfe counties, Kentucky: U.S. Geological Survey Hydrologic Atlas HA-37, 3 pl.

Quinones, Ferdinand, Mull, D. S., York, Karen, and Kendall, Victoria, 1981, Hydrology of Area 14, Eastern Coal Province, Kentucky: U.S. Geological Survey Water-Resources Investigations Open-File Report 81-137, 82 p.

Riggs, H. C., 1972, Low-flow investigations: U.S. Geological Survey Techniques of WaterResources Investigations, book 4, chap. B1, 18 p.

Roth, D. K., Engelke, M. J., Jr., and others, 1981, Hydrology of Area 4, Eastern Coal Province, Pennsylvania, Ohio, and West Virginia: U.S. Geological Survey Water-Resources Investigations Open-File Report 81-343, 62 p.
Runner, G. S., 1980, Runoff studies on small drainage areas (Technique for estimating magnitude and frequency of floods in West Virginia): U.S. Geological Survey Open-File Report 80-1218, 44 p.

SAS Institute, 1982, SAS user's guide -- Basics: 923 p.

Searcy, J. K., 1959, Flow-duration curves: U.S. Geological Survey Water-Supply Paper 1542-A, $33 \mathrm{p}$.

Sedam, A. C., and Stein, R. B., 1970, Saline ground-water resources of Ohio: U.S. Geological Survey Hydrologic Atlas HA-366, 2 pl.

Swisshelm, R. V., Jr., 1974, Low-flow characteristics of Kentucky streams: U.S. Geological Survey Open-File Report, $1 \mathrm{pl}$.

Trautman, M. B., 1977, The Ohio Country from 1750 to 1977 - a naturalist's view: Ohio Biological Survey Biological Notes No. 10, $26 \mathrm{p}$.

U.S. Department of Agriculture Soil Conservation Service, 1975, General soil map of Kentucky: scale 1: 750,000.

1979, General soil map of West Virginia: scale 1: 500,000 .

U.S. Department of Commerce, National Oceanic and Atmospheric Administration, 1969, Climatological data, West Virginia - annual summary, v. 77 , no. 1-13.

1978, Climatological data - National summary, v. 83 , no. 13,15 .

1980, Climatological data, Ohio, West Virginia, and Kentucky - annual summaries.

U.S. Department of Housing and Urban Development, 1977, Flood insurance study -- Guidelines and specifications for study contractors, $64 \mathrm{p}$.

U.S. Environmental Protection Agency, 1976, Quality criteria for water: Washington, D. C., $256 \mathrm{p}$.

U.S. Geological Survey, 1974a, State of Kentucky, hydrologic unit map: 1 pl.

1974b, State of Ohio, hydrologic unit map: $1 \mathrm{pl}$.

1974c, State of West Virginia, hydrologic unit map: 1 pl.

1976, Land use and land cover, 1973-1975, Huntington, West Virginia; Kentucky; Ohio: U.S. Geological Survey Land-Use Ser. 79-1326.

$1981 \mathrm{a}$, Water resources data for Kentucky, water year 1980: Water-data report KY-80-1, 804 p.

1981b, Water-resources data for Ohio, water year 1980, Appendix A, coal areas: Water-data report $\mathrm{OH}-80-\mathrm{A}, 160 \mathrm{p}$.

$1981 \mathrm{c}$, Water-resources data for Ohio, water year 1980, Volume 1, Ohio River basin: Water-data report OH-80-1, 619 p.

1981d, Water resources data for West Virginia, water year 1980, Appendix, coal areas: Water-data report WV-80-A, $228 \mathrm{p}$. 1982a, Water-resources data for Ohio, 
water year 1981, Volume 1, Ohio River Basin: Water-data report $\mathrm{OH}-81-1,502 \mathrm{p}$. $1982 \mathrm{~b}$, Water-resources data for Ohio, water year 1981, Volume 2, St. Lawrence River basin and statewide project data: Water-data report $\mathrm{OH}-81-2,333 \mathrm{p}$.

Wallace, J. C., Shamsi, R. A., and Deutsch, Morris, 1969, Guyandotte, Big Sandy, and Little Sandy River basins, in Ohio River basin comprehensive survey, appendix E, ground water: Cincinnati, Ohio, U.S. Army Engineer Division, p. 7/1 $7 / 13$.

Webber, E. E., and Bartlett, W. P., Jr., 1977, Floods in Ohio -- Magnitude and frequency: Ohio Department of Natural Resources Division of Water Bulletin 45, $74 \mathrm{p}$. 